UNIVERSIDADE DE SÃO PAULO

FACULDADE DE ODONTOLOGIA

\title{
AVALIAÇÃO IN VITRO DO PAPEL DA CATALASE EM DIVERSAS CONCENTRAÇÕES NA ADESIVIDADE DO MATERIAL RESTAURADOR À DENTINA CLAREADA
}

Dissertação apresentada à Faculdade de Odontologia da Universidade de

São Paulo, para obter o Título de Mestre, pelo Programa de PósGraduação em Odontologia.

Área de Concentração: Endodontia.

São Paulo 
Data da Defesa:

1

Comissão Julgadora

Prof. Dr.:

Julgamento:

Assinatura:

Prof. Dr.:

Julgamento:

Assinatura:

Prof. Dr.:

Julgamento:

Assinatura: 
UNIVERSIDADE DE SÃO PAULO

FACULDADE DE ODONTOLOGIA

\section{AVALIAÇÃO IN VITRO DO PAPEL DA CATALASE EM DIVERSAS CONCENTRAÇÕES NA ADESIVIDADE DO MATERIAL RESTAURADOR À DENTINA CLAREADA}

Dissertação apresentada à Faculdade de Odontologia da Universidade de São Paulo, para obter o Título de Mestre, pelo Programa de PósGraduação em Odontologia.

Área de Concentração: Endodontia.

Orientador: Prof. Dr. Marcelo dos Santos.

São Paulo 


\section{Catalogação-na-Publicação}

Serviço de Documentação Odontológica

Faculdade de Odontologia da Universidade de São Paulo

\section{Buendia, Silvia Helena}

Avaliação in vitro do papel da Catalase em diversas concentrações na adesividade do material restaurador a dentina clareada / Silvia Helena Buendia; orientador Marcelo dos Santos. - São Paulo, 2003.

120p. : il.: figs., tabs.

Dissertação (Mestrado - Programa de Pós-Graduação em Odontologia. Área de Concentração: Endodontia) -- Faculdade de Odontologia da Universidade de São Paulo.

1. Tratamento endodôntico, clareamento, restauração, Catalase

CDD 617.6342

BLACK D24 
"Pode-se viver no mundo uma vida magnífica, quando se sabe trabalhar e amar. Trabalhar pelo que se ama e amar aquilo em que se trabalha."

Leon Tolstoi

"Ninguém pode construir em teu lugar as pontes que precisarás passar, para atravessar o rio da vida ninguém exceto tu, só tu."

Friedrich Wilhelm Nietzsche (1844-1900) 


\section{DEDICATÓRIA}

Dedico este trabalho aos meus filhos, os gêmeos Fernando e Beatriz, razões maiores de minha existência, pela felicidade com que adornam cada instante do meu caminho.

Dedico também aos meus pais Álvaro Vera Buendia e Neusa Rodrigues Buendia e aos meus irmãos Luis Antônio, Ana Carolina e Ana Paula pelo amor e carinho constantes. 


\section{AGRADECIMENTOS}

Ao meu Orientador Prof. Dr. Marcelo dos Santos pelo apoio e estímulo em cada fase deste trabalho.

À Profa. Dra. Maria Aparecida Nicoletti pela inestimável colaboração na realização deste trabalho.

Ao amigo Júnio Pereira de Sá, meu muito obrigado.

Aos Professores da Disciplina de Endodontia do Departamento de Dentística da Faculdade de Odontologia da Universidade de São Paulo, São Paulo(SP): Prof. Dr. João Humberto Antoniazzi, Prof. Dr. Hildeberto Francisco Pesce (in memorian), Prof. Dr. Antônio Carlos Bombana, Prof. Dr. Carlos Eduardo Aun, Prof. Dr. Abílio Albuquerque Maranhão de Moura, Prof. Dr. José Luiz Lage Marques, Prof. Dr. Manoel Eduardo de Lima Machado, Prof. Dr. Igor Prokopowitsch, Prof. Dr. Giulio Gavini, Prof. Dr. Celso Luiz Caldeira. 
Aos colegas do Curso de Mestrado: Arturo, Cláudia, Cristina, Crystiane, Diana, Elce, Érico, Evandro, Liliane, Marili, Paula e Weber.

Aos funcionários das Disciplinas de Dentística e Endodontia do Departamento de Dentística da Faculdade de Odonologia da Universidade de São Paulo, São Paulo(SP): Arnaldo, Aldo, Luisinho, Neuza, Ana Maria e David.

A todos aqueles que de alguma forma contribuíram para a realização deste trabalho. 


\section{SUMÁRIO}

p.

LISTA DE FIGURAS

LISTA DE TABELAS

LISTA DE GRÁFICOS

LISTA DE ABREVIATURAS E SIGLAS

LISTA DE SÍMBOLOS

RESUMO

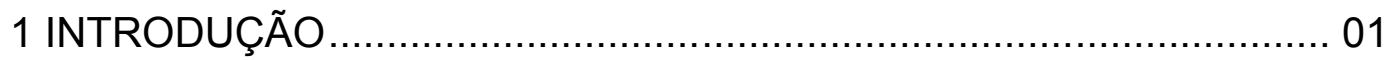

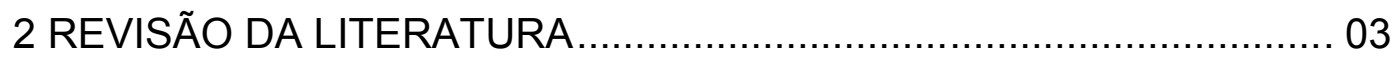

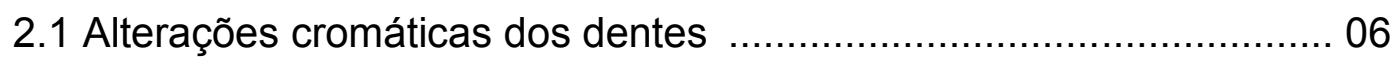

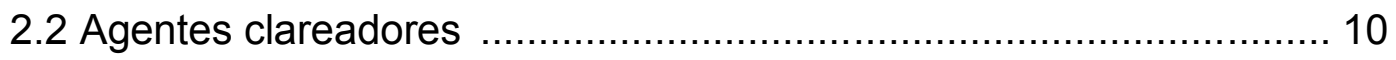

2.3 Mecanismo de ação dos agentes clareadores ............................. 14

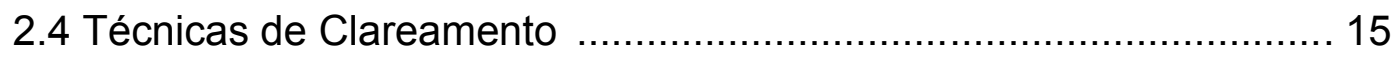

2.5 Efeitos dos agentes clareadores sobre as estruturas dentais .......... 18

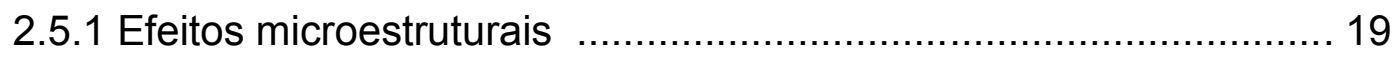

2.5.2 Diminuição da resistência à fratura dos dentes tratados

endodondicamente associada ao clareamento. 
2.5.3 Reabsorção Radicular Cervical Externa em dentes tratados

endodondicamente associada ao clareamento

2.5.4 Redução da adesividade dos materiais restauradores em

dentes clareados .39

2.5.5 Recidiva do manchamento .53

2.5.6 Outros efeitos adversos .54

2.6 Restauração dos dentes tratados endodonticamente e clareados .....56

2.7 Catalase .58

3 PROPOSIÇÃO. 67

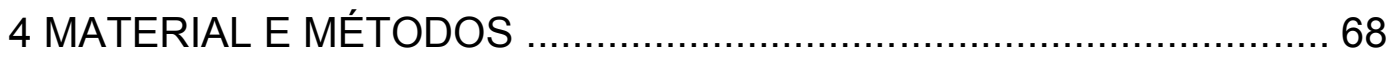

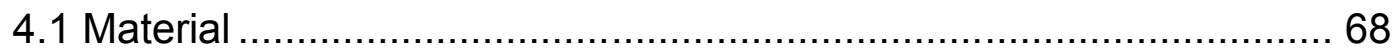

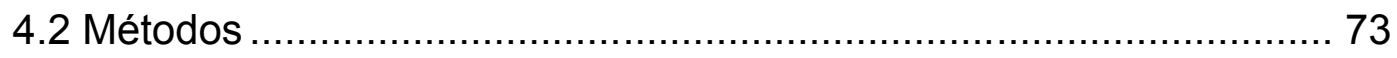

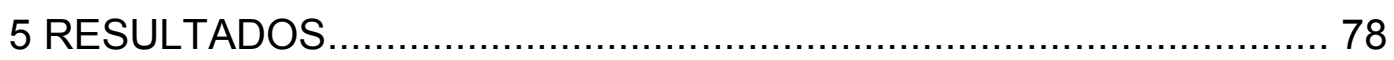

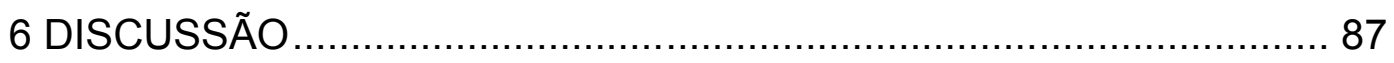

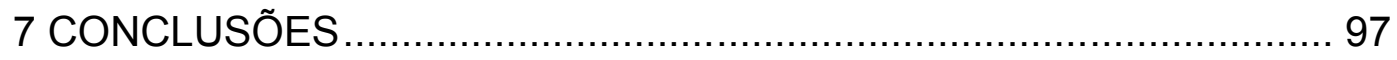

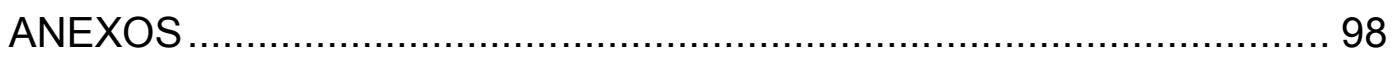

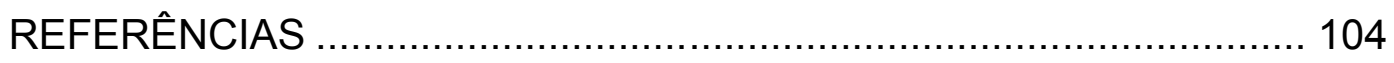

GLOSSÁRIO

SUMMARY

APÊNDICE 


\section{LISTA DE FIGURAS}

Fig. 1 - Máquina de corte de precisão LABCUT 1010 (EXTEC) para confecção dos espécimes através de seccionamentos transversais e longitudinais dos dentes 70

Fig. 2 - Máquina Politriz Ecomet 3 (Buehler Ltda.) para polimento dos espécimes incluídos em discos de resina acrílica transparente autopolimerizável 71

Fig. 3 - Espécimes incluídos em discos de resina acrílica transparente autopolimerizável confeccionados em matriz desmontável (anel e fundo) 71

Fig. 4 - Espécimes incluídos em discos de resina acrílica transparente e imersos nas soluções experimentais 72

Fig. 5 - Matriz de TEFLON …........................................................... 72

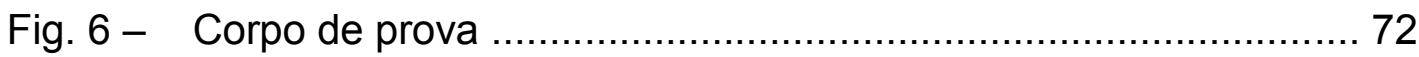

Fig. 7 - Máquina de Teste Universal Instron mod. 4442 (Instron Corp., Canton, MA., EUA) para ensaios de tração 73 


\section{LISTA DE TABELAS}

Tabela $\quad 1-$ Grupos experimentais segundo as soluções testadas 76

Tabela $\quad 2$ - Valores das Resistências Adesivas à fratura dos corpos de prova dos grupos experimentais e de seus respectivos grupos controle 80

Tabela $\quad 3$ - Médias Aritméticas dos valores das Resistências Adesivas à fratura dos corpos de prova nos grupos experimentais e em seus respectivos grupos controle 81

Tabela $\quad 4$ - Teste de Aderência à Curva Normal para as amostras dos espécimes tratados com Catalase 83

Tabela $\quad 5$ - Teste de Kruskal-Wallis para os grupos experimentais Catalase 84

Tabela 6 - Comparação das Médias dos grupos experimentais

Catalase 84

Tabela $\quad 7$ - Teste U de Mann-Whitney para as comparações dos grupos experimentais com seus respectivos controle 85

Tabela An.A8 - Valores originais das forças de tração necessárias para a fratura dos corpos de prova de cada um dos espécimes dos 
grupos experimentais e de seus respectivos grupos controle .98

Tabela An.A9 - Médias Aritméticas dos valores originais das forças de tração necessárias para a fratura dos corpos de prova dos grupos experimentais e dos seus respectivos grupos controle 100

Tabela An.A10 - Teste de Normalidade das amostras de espécimes tratados com Catalase - Parâmetros Amostrais 101

Tabela An.A11 - Teste de Normalidade das amostras de espécimes tratados com Catalase - Distribuição de Freqüências 101

Tabela An.A12 - Teste de Normalidade das amostras de espécimes tratados com Soro Fisiológico (Grupos Controle) - Parâmetros Amostrais 102

Tabela An.A13 - Teste de Normalidade das amostras de espécimes tratados com Soro Fisiológico (Grupos Controle) - Distribuição de Freqüências 102

Tabela An.A14 - Teste de Aderência à Curva Normal para as amostras dos espécimes tratados com Soro Fisiológico 103

Tabela An.A15 - Teste de Kruskal-Wallis para os grupos controle 103

Tabela An.A16 - Comparação da Médias dos grupos controle 103 



\section{LISTA DE GRÁFICOS}

Gráfico 1 - Valores das Resistências Adesivas dos grupos experimentais Catalase 80

Grafico $\quad 2$ - Valores das Resistência Adesivas dos grupos Controle .. 81

Gráfico 3 - Médias Aritméticas dos valores das Resistências Adesivas dos corpos de prova dos grupos experimentais e de seus respectivos grupos controle .83

Gráfico An.A4 - Valores originais das forças de tração necessárias para a fratura dos corpos de prova de cada um dos espécimes dos grupos experimentais 99

Gráfico An.A5 - Valores originais das forças de tração necessárias para a fratura dos corpos de prova de cada um dos espécimes dos grupos controle .99

Gráfico An.A6 - Médias Aritméticas dos valores originais das forças de tração necessárias para a fratura dos corpos de prova nos grupos experimentais e nos seus respectivos grupos controle .100 


\section{LISTA DE ABREVIATURAS E SIGLAS}

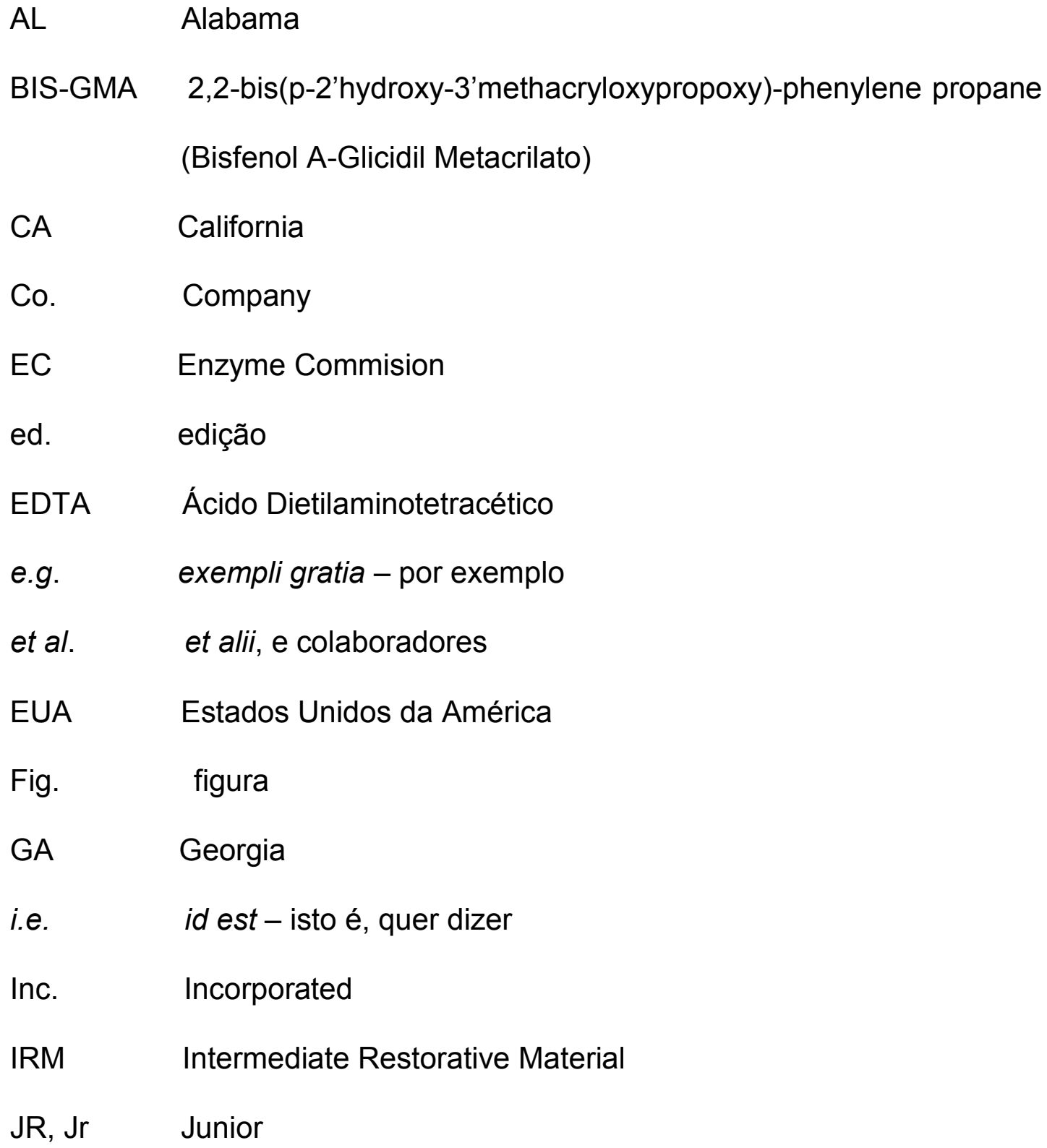




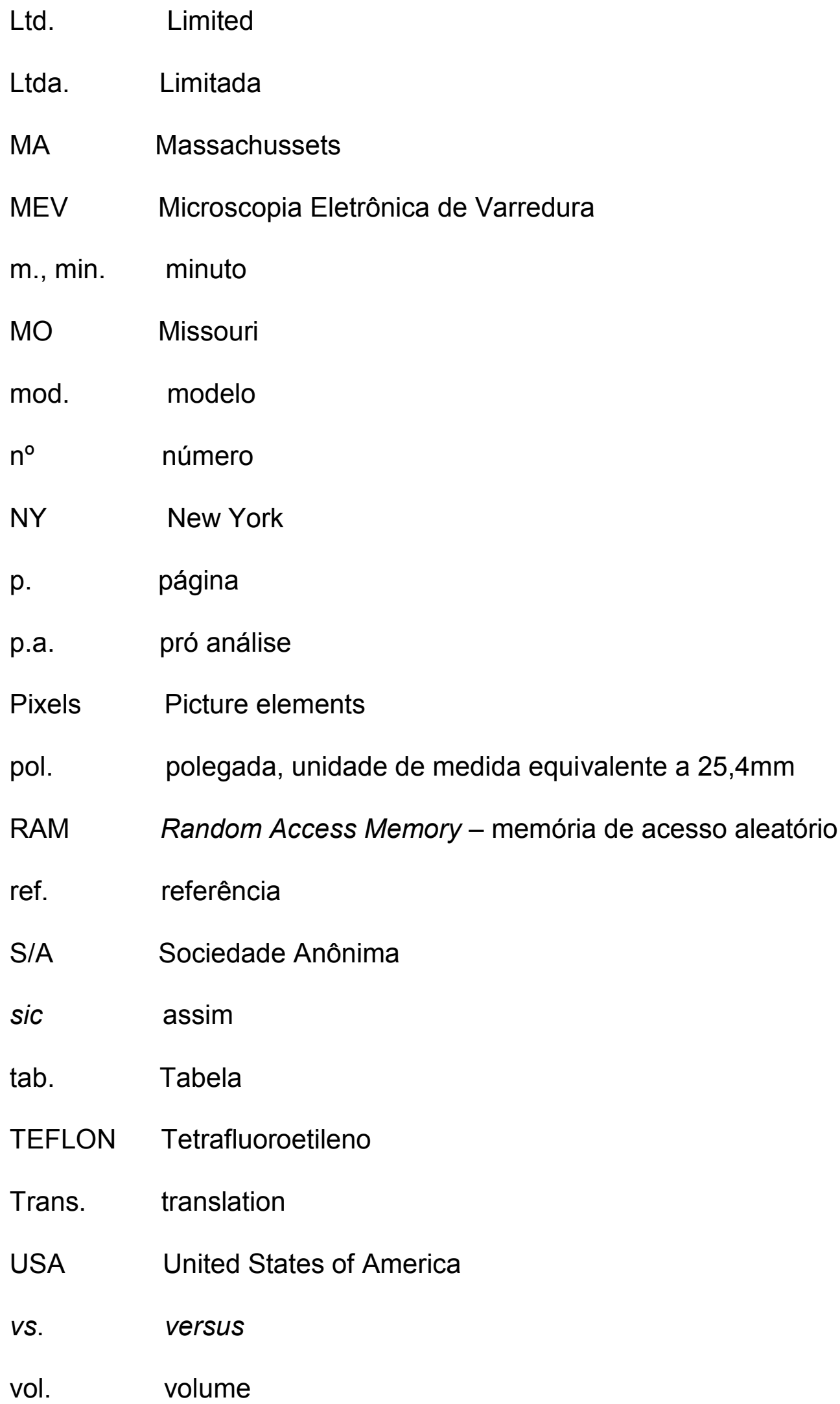




\section{LISTA DE SÍMBOLOS}

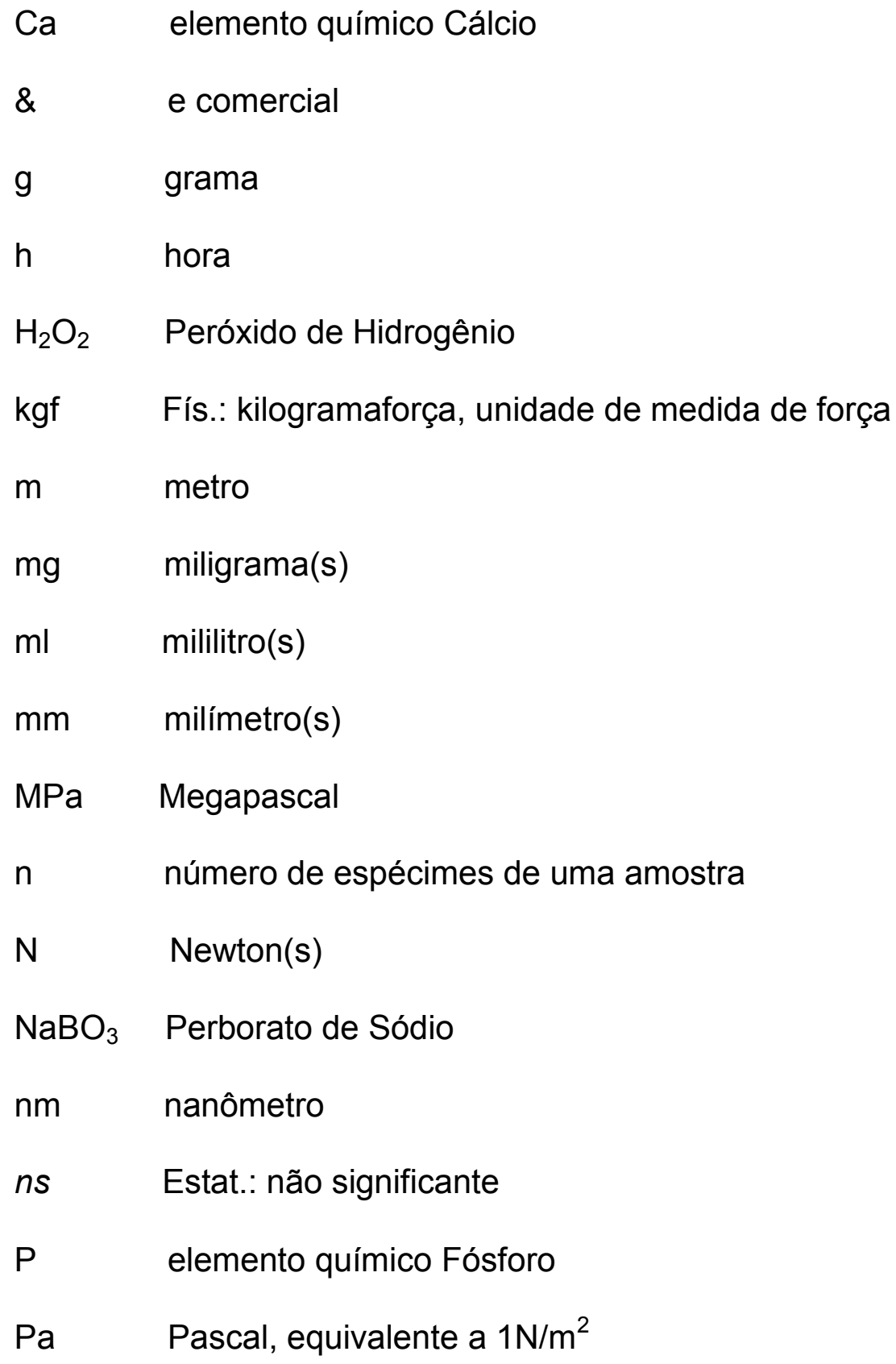




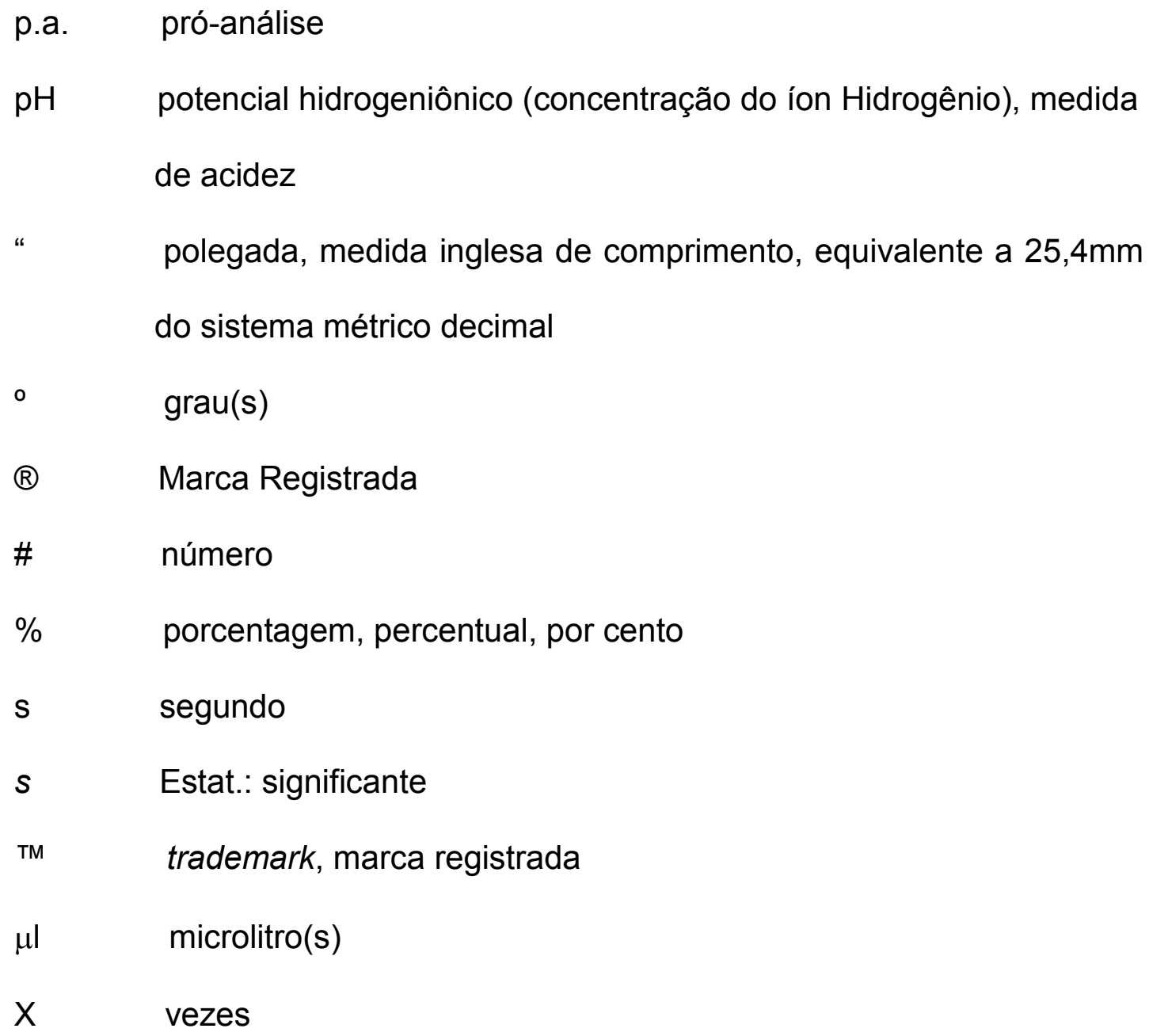




\section{RESUMO}

\section{AVALIAÇÃO IN VITRO DO PAPEL DA CATALASE EM DIVERSAS CONCENTRAÇÕES NA ADESIVIDADE DO MATERIAL RESTAURADOR À DENTINA CLAREADA}

As alterações cromáticas dos dentes têm etiologia diversa e podem surgir da atuação de fatores intrínsecos e extrínsecos. As alterações decorrentes de fatores intrínsecos, por sua vez, podem ser classificadas como de natureza congênita ou adquiridas. Estas últimas podem manifestar-se antes ou após a erupção do dente e incluem as alterações cromáticas dos dentes portadores de polpa morta e dos dentes endodonticamente tratados. Procedimentos inadequados durante o tratamento endodôntico, como deixar permanecer restos necróticos no interior da câmara coronária após a cirurgia de acesso ou o emprego de substâncias medicamentosas na forma de medicação intracanal ou de cimento obturador, podem promover a pigmentação da coroa. Em 1850, Dwinelle propôs o emprego de uma bolinha de algodão impregnada de peróxido de hidrogênio a $30 \%$ que deveria permanecer no interior da câmara coronária entre duas sessões clínicas. Os primeiros efeitos adversos do tratamento clareador foram descritos por Harrington \& 
Natkin em 1979 ao relatarem 4 casos clínicos de reabsorções radiculares cervicais externas. Entre outros efeitos adversos têm-se relatado a diminuição da adesividade do material restaurador à dentina clareada por falhas de ordem tanto adesiva como coesiva. Segundo os pesquisadores tal efeito estaria relacionado às alterações microestruturais e à presença de oxigênio residual na dentina que interfeririam com a polimerização do material restaurador. Em 1993 Rotstein utilizou in vitro a enzima Catalase para impedir sua difusão de oxigênio para a superfície radicular externa. No atual experimento avaliou-se o papel da Catalase na neutralização de peróxido de hidrogênio residual com vistas a devolver ao dente suas características normais de adesividade. Os resultados mostraram haver diferenças estatisticamente significantes entre as soluções de $10 \mathrm{mg}$ e $250 \mathrm{mg}$ e entre as soluções de $50 \mathrm{mg}$ e $250 \mathrm{mg}$, quanto à adesividade do material restaurador, de tal forma que a solução de $250 \mathrm{mg}$ promoveu maiores valores de resistência adesiva tanto em relação a de $10 \mathrm{mg}$ como em relação a de 50mg. Não verificou-se diferenças estatisticamente significantes entre os grupos experimentais e seus respectivos grupos controle. Dadas as condições experimentais concluiu-se que a Catalase na concentração de $250 \mathrm{mg}$ restaurou a adesividade da estrutura dentinária clareada. 


\section{INTRODUÇÃO}

É inegável que vivemos um momento em que a sociedade globalizada percebe a Estética como um reflexo direto da condição de saúde.

De uma forma geral, no que tange à Odontologia, os padrões de beleza estão associados à harmonia entre os vários aspectos relacionados aos dentes tais como a forma, a simetria, o número e principalmente a sua cor. Assim, do ponto de vista cosmetológico, a super valorização da Estética acabou por determinar nas últimas décadas a busca de materiais e técnicas restauradores que melhor atendessem às expectativas do paciente.

Por outro lado, a Odontologia Cosmética têm exigido do Clínico uma postura cada vez mais crítica com relação tanto aos novos materiais restauradores como às técnicas desenvolvidas para o emprego dos mesmos.

Dentro do contexto da relação entre as várias modalidades de tratamento a serem instituídas para o alcance dos referidos padrões estéticos o Clareamento Dental surge como forma terapêutica conservadora isolada ou associada às manobras de restauração do elemento dental com vistas a devolver ao paciente a integridade estética relacionada aos dentes. 
Do ponto de vista etiopatogênico, as alterações cromáticas dos dentes podem originar-se tanto intrínseca como extrinsicamente manifestando-se como conseqüência de defeitos de formação tanto do esmalte como da dentina, de cárie, como decorrência de traumatismo dentário assim como iatrogenia do tratamento endodôntico.

Substâncias oxirredutoras têm sido empregadas há pelo menos um século com vistas à degradação das substâncias pigmentantes da estrutura dentária em substâncias de menores índices de refração de luz e que não promovam o escurecimento da coroa dentária.

A alusão a possíveis efeitos adversos do tratamento clareador somente foram sugeridas em 1979, quando Harrington e Natkin relataram casos clínicos de reabsorção radicular cervical externa em pacientes previamente submetidos ao tratamento clareador com um agente clareador amplamente utilizado, o peróxido de hidrogênio.

$\mathrm{Na}$ última década alguns pesquisadores têm sugerido o comprometimento da adesividade da dentina em função das alterações microestruturais e do oxigênio residual decorrentes do tratamento clareador. O peróxido de hidrogênio residual ao interferir com a coesividade do adesivo dentinário, inibindo sua polimerização, determinaria uma redução da adesividade do material restaurador à estrutura dentinária.

A Catalase de fígado bovino, um oxirredutor biológico natural, foi sugerida como um neutralizador do peróxido residual impedindo ao nível experimental a sua difusão para o meio extrarradicular. 


\section{REVISÃO DA LITERATURA}

O clareamento dental tem sido alvo de atenção da Odontologia já há mais de um século decompondo substâncias químicas que penetraram a estrutura dental e promoveram o seu escurecimento. Mais recentemente, associada à Odontologia Restauradora Cosmética, restabelecendo a integridade estética do paciente relacionada aos dentes.

Dwinelle (1850) descreveu sua técnica de clareamento de dentes endodonticamente tratados, o Walking Bleach, que consistia na colocação de uma bolinha de algodão impregnada de peróxido de hidrogênio a 30\% no interior da câmara coronária onde permanecia entre duas sessões clínicas (Teixeira et al., 2000).

Em 1861 M'Quillen aludia para que o restabelecimento da normalidade cromática dos dentes implicava o conhecimento das características químicas das substâncias que promoviam o escurecimento dos dentes e que, sem os conhecimentos da Química, qualquer abordagem seria de ordem essencialmente empírica. Então, sugere como agentes clareadores o dióxido de enxofre e o licor de Labarraque, solução de hipoclorito de sódio a 2,5\% que fora preconizada por Woodnut em 1860. Após suas observações microscópicas das estruturas dentais em 1866, o 
pesquisador evidencia o caráter oxirredutivo dos agentes clareadores em relação aos agentes responsáveis pelas alterações cromáticas dos dentes (Pécora et al., 1996a).

O clareamento de dentes portadores de polpa viva foi realizado por Latimer em 1868 com o ácido oxálico, por Fisher em 1911 com o peróxido de hidrogênio e por Atkinson em 1868 com a pirozona (Baratieri et al., 1996a).

No que diz respeito ao emprego de outras substâncias químicas no clareamento dental Bogue, em 1872, e Chappel, em 1877, propuseram o emprego do ácido oxálico e Truman empregava o hipoclorito de cálcio desde 1881. O dióxido de hidrogênio a $3 \%$ e o cloreto de alumínio, como agentes clareadores, foram propostos por Harlan em 1884 e em 1893 Kirk sugeria o uso do dióxido de sódio. Acredita-se que Harlan, em 1884, tenha sido o pioneiro no emprego do peróxido de hidrogênio como agente clareador. Em 1895 Westlake sugeriu a pirozona, uma mistura de cinco partes de peróxido de hidrogênio a $25 \%$ e uma de éter, e o calor para ativação do agente clareador através da aplicação de corrente elétrica (Goldstein et al. 1994; Pécora et al., 1996a; Teixeira et al., 2000).

Desde então, a partir de uma melhor aceitação tanto pelo profissional como pelo paciente, o clareamento dental foi amplamente empregado no último século.

Ao longo da primeira década do século passado as técnicas de clareamento dental consistiam no emprego do peróxido de hidrogênio 
ativado por um instrumento aquecido ou por uma fonte de luz (Baratieri et al., 1996a).

Abbot apresentou, em 1918, uma técnica de clareamento dental em que uma solução de peróxido de hidrogênio a 30\%, o peridrol, era ativada pela luz de uma lâmpada elétrica (Teixeira et al., 2000).

Herman Prinz (1924) propôs uma técnica de clareamento dental em que empregava calor de uma lâmpada elétrica, aplicada de 15 a 20min., como catalisador da reação química entre o superoxol (solução de peróxido de hidrogênio a $30 \%$ ) e o perborato de sódio. Segundo o autor 3 a 4 sessões seriam usualmente necessárias para que se atingisse a tonalidade desejada.

Em 1937, Ames empregou uma mistura de cinco partes de peróxido de hidrogênio a $30 \%$ e éter, catalisada pelo calor, no clareamento de dentes portadores de polpa viva e cromaticamente alterados por manchas extrínsecas. Salvas (1938) e Spasser (1961) propuseram uma pasta à base de perborato de sódio e água destilada que deveria ser colocada no interior da câmara coronária de dentes tratados endodonticamente, onde permaneceria durante vários dias (Pécora et al. 1996a).

Nutting \& Poe em 1963, modificando a técnica de clareamento dental de dentes tratados endodonticamente proposta por Herman Prinz em 1924, sugeriram o emprego de uma pasta de peróxido de hidrogênio a $30 \%$ e perborato de sódio mas sem o uso de calor.

Em 1980 Howell relatou resultados satisfatórios com a aplicação de ácido ortofosfórico, para exposição dos túbulos dentinários, antes da aplicação do agente clareador (Teixeira et al., 2000). 
O clareamento dental sofreu uma grande revolução quando em 1989 Haywood \& Heymann apresentaram uma técnica de clareamento de dentes portadores de polpa viva, o Home Bleaching (clareamento caseiro), que prescrevia o emprego de um gel de peróxido de carbamida a $10 \%$ que poderia ser aplicado pelo próprio paciente em sua residência.

\subsection{ALTERAÇÕES CROMÁTICAS DOS DENTES}

As alterações cromáticas dos dentes, isoladamente ou em grupo, podem constituir situações desagradáveis que levarão os pacientes a procurarem o tratamento odontológico. A cor dos dentes é distinta entre os indivíduos, podendo variar de branco-azulado a cinza-escuro ou marron, e os dentes são policromáticos em função das várias cores dos tecidos que os compõem (Pécora et al., 1996b).

De acordo com Baratieri et al. (1996b) e Berger et al. (1998) as alterações cormáticas dos dentes podem ser classificadas em (1) manchas causadas por fatores intrínsecos; (2) manchas causadas por fatores extrínsecos e (3) manchas decorrentes da associação dos dois fatores.

Segundo Pécora et al. (1996b), quanto à etiologia, as alterações de cor dos dentes podem ser classificadas em endógenas, exógenas, medicamentosas e iatrogênicas.

As alterações cromáticas causadas por fatores extrínsecos são muito freqüentes e caracterizadas pela presença do agente pigmentante junto à 
superfície do dente. O surgimento destes pigmentos está associado ao consumo exagerado de café, chá, chimarron, cigarro, charutos e cachimbos, alimentos corantes assim como ao acúmulo de placa bacteriana. $\mathrm{O}$ tratamento consiste, na maioria das vezes, na sua remoção mecânica através de profilaxia com taça de borracha e pasta abrasiva. Podemos ainda lançar mão de abrasão com jato de bicabornato de sódio, equipamentos ultrassônicos e, em casos mais severos, raspagem e alisamento coronoradicular, sempre acompanhados da orientação do paciente quanto à dieta e higiene (Baratieri et al., 1996b).

As alterações de cor causadas por fatores intrínsecos são tanto mais complexas quanto mais difíceis de serem tratadas e envolvem o esmalte e a dentina, combinados ou isoladamente, somente podendo serem removidas através do clareamento, abrasão ou restauração do elemento dental acometido (Baratieri et al., 1996b).

Segundo Albers (1988) as alterações de cor intrínsecas podem ser classificadas, segundo a etiologia, em congênitas e adquiridas (Baratieri et al., 1996b).

As alterações de cor intrínsecas congênitas compreendem as alterações de formação do dente como a hipoplasia do esmalte, a amelogênese Imperfeita, a hipercalcificação do esmalte (mancha branca), a dentinogênese Imperfeita e a fluorose (Baratieri et al., 1996b e Pécora et al., 1996b).

Por outro lado, as alterações cromáticas intrínsecas adquiridas podem ser subdivididas em pré e pós eruptivas (Baratieri et al., 1996b). 
As alterações cromáticas intrínsecas adquiridas pré eruptivas estão associadas à substâncias produzidas em doenças sistêmicas representadas, principalmente, pela eritroblastose fetal, icterícia, tifo, cólera e porfiria congênita, e que possuem a capacidade de se fixarem às estruturas dentárias e alterarem sua cor. Essas variações temporárias acometem apenas dentes portadores de polpa viva e normalmente desaparecem com a cura da doença. Nesta categoria também se incluem as manchas decorrentes do uso indevido de tetraciclina, antibiótico de largo espectro de ação, ou fluor. As tetraciclinas promovem a alteração da estrutura dentinária durante o desenvolvimento do dente. Segundo Feinman et al. (1987) as manchas causadas pelas tetraciclinas podem ser classificadas em manchas de primeiro, segundo, terceiro e quarto graus. As manchas causadas pelo excesso de fluor podem ser simples, opacas ou porosas (Baratieri et al., 1996b e Pécora et al., 1996b).

As manchas adquiridas pós eruptivas compreendem as alterações cromáticas decorrentes de necrose pulpar e reabsorção interna, como conseqüência de cárie e traumatismo dentário, e a abrasão. As manchas causadas pelas tetraciclinas podem também serem consideradas manchas intrínsecas adquiridas após a erupção (Baratieri et al, 1996b e Pécora et al., 1996b).

Após o traumatismo do elemento dentário a hemorragia pulpar, causa mais comum de escurecimento dentário pós trauma, resulta no fluxo de sangue para o interior dos canalículos dentinários, onde as hemácias se degradam liberando hemoglobina, oxiemoglobina, metaemoglobina, 
hematoidina, hematina e hemina. A degradação da hemoglobina promove a liberação de ferro que ao combinar-se com sulfeto de hidrogênio resulta na formação de sulfeto de ferro, um composto escuro. Como conseqüência de traumatismo podemos ter ainda a necrose pulpar, a obliteração da câmara pulpar por calcificações e reabsorção dentinária interna ou externa, que podem levar ao escurecimento do dente (Baratieri et al., 1996b, Pécora et al., 1996b).

As alterações de cor não decorrentes de cárie ou traumatismo dentário incluem o processo fisiológico de envelhecimento do órgão dental. Os canalículos dentinários são mais amplos em indivíduos jovens e sua obliteração aumenta com a idade. A polpa dental, por sua vez, é mais ampla e menos fibrosa em jovens e mais retraída em idosos. Essas variações fisiológicas provocam diferenças de coloração nos dentes em função da idade. As alterações cromáticas devido ao envelhecimento devem-se, principalmente, ao desgaste fisiológico do esmalte e à conseqüente transparência da dentina (Pécora et al., 1996b).

Podemos ainda citar as alterações cromáticas dentárias de natureza iatrogênica promovidas por fármacos de uso odontológico como o eugenol e o lodofórmio usados no tratamento endodôntico. O eugenol deixado no interior da câmara coronária como medicação intracanal por alguns profissionais pigmenta irreversivelmente a estrutura dentária. A cirurgia de acesso ao conduto radicular inadequadamente realizada pode resultar na presença de remanescentes pulpares necróticos, no interior da câmara coronária, que se degradam e a pigmentam. Da mesma forma, cimentos 
obturadores e gutta-percha remanescentes na câmara coronária, após a conclusão do tratamento endodôntico, poderão interferir com a cor do dente. Pode-se observar, ainda, a ocorrência de pigmentação do dente decorrente de restaurações metálicas como o amálgama usadas na restauração da coroa dentária (Pécora et al., 1996b).

\subsection{AGENTES CLAREADORES}

Buckley, 1950, relaciona o bióxido de sódio, o peróxido de hidrogênio, acetozono (bióxido de benzoilacetila obtido por oxidação de uma mistura de anidrido acético e benzaldeído), alfozono ou bióxido succínico (peróxido de hidrogênio combinado com anidrido succínico) e o ácido oxálico compondo um grupo de substâncias químicas oxidantes empregadas no passado para fins de clareamento dental. Descreve ainda o emprego de compostos de cloro (cloreto de cálcio e solução de hipoclorito de sódio a 2,5\% (licor de Labarraque) como clareadores oxidantes de ação indireta e o ácido sulfuroso empregado como agente redutor.

Segundo Grossman (1954) a finalidade do clareamento dental consiste na restauração da cor normal do dente através da remoção dos pigmentos responsáveis pelas alterações cromáticas do dente empregandose substâncias químicas oxidantes ou redutoras. Considera, ainda, que o branqueamento com agentes oxidantes diretos, como a pirozona e o peróxido de hidrogênio, são mais simples e seguros. 
Frysh et al. (1995) compararam soluções de peróxido de hidrogênio com diferentes $\mathrm{pH}, 4,4$ e 9, quanto a sua capacidade de dentes escurecidos e concluíram que o peróxido de hidrogênio com pH 9 (básico) é mais efetivo que o de pH 4,4 (ácido) possibilitando melhores resultados e diminuição dos efeitos adversos em relação às estruturas dentais.

Atualmente, os agentes clareadores mais comumente empregados, tanto intra como extracoronalmente, são o peróxido de hidrogênio $\left(\mathrm{H}_{2} \mathrm{O}_{2}\right)$, o perborato de sódio $\left(\mathrm{NaBO}_{3}\right)$ e o peróxido de carbamida (ou peróxido de uréia).

O peróxido de hidrogênio é o agente mais efetivo e mais utilizado para clarear os dentes, podendo ser usado isoladamente ou associado com o perborato de sódio. O peróxido de hidrogênio pode ser empregado em várias concentrações, sendo mais utilizado nas concentrações de 30\% e 35\%. Na concentração de $35 \%$ é conhecido como superoxol ou peridrol. O peróxido de hidrogênio a $30 \%$ apresenta alta capacidade de penetrar tanto o esmalte como a dentina devido ao seu baixo peso molecular oxidando os pigmentos localizados em tais estruturas. Em solução aquosa o peróxido de hidrogênio se decompõe nos radicais peridroxil e hidroxil que são altamente reativos. Dessa forma, o peróxido de hidrogênio possui capacidade tanto de reduzir como de oxidar os elementos com os quais reage atuando também, mecanicamente, na limpeza da sujidade. No processo de denaturação e degradação de proteínas são liberados polipeptídeos e, finalmente, aminoácidos de baixo peso molecular. $O$ oxigênio ativo é capaz de agir nas 
cadeias peptídicas transformando seus componentes em elementos hidrossolúveis (Baratieri et al., 1996c).

O peróxido de hidrogênio é bacteriostático em alta concentração e em concentrações muito altas é mutagênico. A solução de peróxido de hidrogênio a $30 \%$ é bastante cáustica e exige bastante cuidado em sua manipulação pelo profissional. A solução dever ser armazenada em frasco de cor âmbar e conservada em geladeira evitando-se sua degradação (Baratieri et al., 1996c).

O perborato de sódio é um agente oxidante que se apresenta na forma de um pó branco estável de granulação espessa que misturado com água decompõe-se em peróxido de hidrogênio e oxigênio. Poderá ser utilizado isoladamente ou misturado com peróxido de hidrogênio até que se obtenha uma pasta espessa para ser inserida no interior da câmara pulpar como curativo de demora para um clareamento interno contínuo.

O peróxido de carbamida é um péróxido de hidrogênio unido à uréia em uma base anidro de glicerina ou em uma base solúvel de carbopol (é um polímero que atua na velocidade de liberação de oxigênio). Tem baixo peso molecular e consegue igualmente movimentar-se através das estruturas de esmalte e dentina. Sua eficiência como agente clareador está relacionada com sua capacidade de liberar oxigênio ativo e radicais livres hidrossolúveis.

Considerando a questão da reabsorção radicular cervical como conseqüência indesejável do tratamento clareador intracoronário, Teixeira et al. (2000) sugerem o seguinte protocolo para o tratamento clareador dos dentes endodonticamente tratados: (1) a avaliação clínica e radiográfica do 
tratamento endodôntico, (2) o registro da cor do dente, (3) a confecção de uma barreira intracanal cervical com Cavit de $2 \mathrm{~mm}$ de espessura posicionada abaixo da junção amelo-cementária (3) limpeza da câmara com solução de álcool e éter, (4) aplicação de EDTA a 17\% entre 3 e $5 \mathrm{~min}$. ou ácido ortofosfórico a 37\% por 30s, (5) lavagem e secagem, (6) confecção de uma pasta contendo $2 \mathrm{~g}$. de perborato de sódio e $1 \mathrm{ml}$ de água destilada e sua colocação no interior da câmara pulpar e (7) selamento provisório. Na sessão seguinte devemos repetir, todos os procedimentos anteriores, renovando-se a pasta clareadora. Em média, obtém-se o resultado desejado em torno de 3 a 4 sessões com trocas semanais. Concluído o tratamento, remove-se toda a pasta, lava-se abundantemente a câmara coronária e selase a mesma com cimento provisório por 7 dias antes da seleção do material restaurador definitivo, tendo-se em conta uma possível discreta reversão da tonalidade de cor. Os autores sugerem que caso não se alcance o resultado desejado deve-se espaçar as sessões realizando-se trocas em torno de 30 dias. Sugerem, inclusive, o emprego alternativo do superoxol, lembrando dos riscos relacionados ao seu emprego. Os autores aconselham o emprego do perborato de sódio tri ou tetrahidratado associado a água como agente de escolha para o clareamento de dentes não vitais devido a sua atuação eficiente e baixo risco de reabsorção cervical externa. 


\subsection{MECANISMO DE AÇÃO DOS AGENTES CLAREADORES}

Segundo Goldstein et al. (1994) o efeito do agente clareador depende diretamente da natureza do agente pigmentante, dos tecidos dentários envolvidos, da profundidade e do tempo de pigmentação assim como da capacidade do agente clareador de permear a estrutura dentária e alcançar a fonte de descoloração e aí permanecer tempo suficiente para a liberação da mesma.

Segundo Zaragoza (1984) o mecanismo molecular do clareamento dentinário dá-se quando o peróxido de hidrogênio reage com a dupla ligação do composto cromatóforo rompendo-a por meio da adição do oxigênio levando à formação de um diol, o que acarretaria a perda do caráter pigmentante da substância escurecedora. Os peróxidos são substâncias químicas de natureza eletrófila e atuam ora como oxidantes, com a formação de oxigênio combinado, ora como redutores com a formação de oxigênio molecular. O peróxido de hidrogênio é um ácido fraco e sua dissociação é incrementada através do aumento da temperatura, do tempo e do pH (Paiva \& Antoniazzi, 1988).

O clareamento resulta na formação de substâncias químicas intermediárias de cor mais clara através da conversão de substâncias orgânicas em dióxido de carbono e água. Inicialmente os anéis de carbono dos agentes pigmentantes são abertos e convertidos em cadeias de cor mais clara. O ponto de saturação corresponde à quantidade ótima de 
clareamento onde o branqueamento máximo é obtido e a partir deste ponto ocorre somente a degradação do agente clareador (Baratieri et al., 1996)

Conforme Baratieri et al. (2001) cadeias moleculares longas e complexas quando presentes na estrutura dentária determinam um aumento do índice de absorção de luz o que em maior ou menor grau acaba por resultar no escurecimento do mesmo. Ainda, segundo os autores, as macromoléculas pigmentantes da estrutura dentária são fracionadas e eliminadas por difusão a partir do contato com os agentes clareadores, substâncias químicas altamente instáveis e que veiculam radicais livres de oxigênio atuando ora como oxidantes, ora como redutores. Quando em contato com os tecidos, o peróxido de hidrogênio se degrada em oxigênio e água, sendo o oxigênio o responsável pelo clareamento. No clareamento com peróxido de carbamida este dissocia-se em peróxido de uréia, que se dissocia em amônia, dióxido de carbono e peróxido de hidrogênio que se dissocia em oxigênio e Água. Por outro lado, o perborato de sódio degradase em peróxido de hidrogênio, menos concentrado, e subseqüentemente em oxigênio ativo.

\subsection{TÉCNICAS DE CLAREAMENTO}

Para Esberard et al. (1996) o avanço tecnológico permitiu à Odontologia a adoção de uma arsenal químico mais seguro e eficaz em detrimento de um outro perigoso, de difícil manipulação e empregado de 
forma empírica. Os autores ainda consideram que o tratamento das alterações cromáticas dos dentes prescreve a obtenção durante o exame clínico do paciente, anamnese e exame físico, de informações relacionadas à causa do escurecimento do elemento dental com vistas à antecipação dos resultados do tratamento.

Segundo Baratieri et al. (2001) as técnicas de clareamento dental traduzem uma abordagem conservadora do tratamento das alterações cromáticas dos dentes e, portanto, devem ser consideradas a primeira alternativa no tratamento estético e de tal forma a permitir que os dentes clareados preservem sua forma, contorno e textura superficial. Dessa forma, os dentes a serem submetidos ao tratamento clareador, independentemente de possuírem polpa viva ou polpa morta, não podem apresentar cárie ou restaurações extensas.

De acordo com Goldstein et al. (1996), o clareamento dental está contra indicado em dentes super sensíveis em função de erosão severa do esmalte, polpas extremamente volumosas, superfícies radiculares expostas ou hiperemia transitória associada à movimentação ortodôntica. Da mesma forma, estaria contra indicado em dentes portadores de manchas ou pintas opacas ou em dentes intensamente pigmentados pelo agente corante.

Ingle et al. (1994) advertem que o dentista deve comunicar ao paciente que o resultado da tentativa de clareamento do elemento dental, nem sempre é permanente e que em alguns casos a recorrência do escurecimento pode implicar a necessidade de nova intervenção. 
De acordo com Baratieri et al. (2001) o clareamento de dentes portadores de polpa viva requer agentes e técnicas clareadores específicos em função do tipo de alteração cromática e, considerados os efeitos secundários, maiores concentrações do agente clareador por tempos mais prolongados normalmente proporcionam melhores resultados. Os autores consideram o tratamento clareador caseiro supervisionado pelo dentista como a melhor alternativa de tratamento clareador dos dentes portadores de polpa viva. A técnica prescreve o registro da cor, moldagem, alívio, confecção e prova da moldeira, instruções de uso e controle periódico.

De acordo com Frank et al. (1983) empregam-se basicamente duas substâncias químicas oxidantes, isolada ou associadamente, no clareamento dos dentes tratados endodonticamente que são o peróxido de hidrogênio e o perborato de sódio através da técnica Walking Bleach ou da técnica Termocatalítica. Segundo os autores, como critérios básicos para o clareamento dos dentes tratados endodonticamente devem ser consideradas a qualidade da obturação do conduto radicular assim como a qualidade da estrutura dental remanescente.

Baratieri et al. (2001) sugerem para o tratamento clareador dos dentes endodonticamente tratados a associação das técnicas Walking Bleach (Técnica Mediata) e Termocatalítica (Técnica Imediata) empregando-se como agentes clareadores o peróxido de hidrogênio a $35 \%$ em água ou na forma de pastilhas ou perborato de sódio associado ao peróxido de hidrogênio em solução. 
No tratamento clareador dos dentes endodonticamente tratados devese considerar em princípio o clareamento extracoronário em detrimento do clareamento intracoronário. Por outro lado, nos casos de escurecimento do dente pela tetraciclina, deve-se considerar a possibilidade de clareamento intracoronário (Baratieri et al., 2001).

\subsection{EFEITOS DOS AGENTES CLAREADORES SOBRE AS} ESTRUTURAS DENTAIS

O tratamento clareador de dentes portadores de alterações cromáticas tem sido realizado há mais de um século com resultados satisfatórios independentemente da substância clareadora ou da técnica empregadas. De uma forma geral os agentes empregados tem sido associados a uma série de efeitos indesejáveis dentre os quais podemos destacar a diminuição da resistência a fratura, reabsorção radicular cervical externa e uma diminuição da adesão dos materiais restauradores. Também podemos considerar como efeito adverso do emprego dos agentes clareadores a recidiva do manchamento. Do ponto de vista metodológico, as alterações têm sido evidenciadas através de Microscopia Eletrônica de Varredura, análise histoquímica, análise cromatográfica, testes de tração e cisalhamento bem como análise espectrofotométrica. 


\subsubsection{Efeitos microestruturais}

Perdigão et al. (1998) considerando as opiniões divergentes quanto aos efeitos adversos do clareamento em relação à força de união dos sistemas adesivos, realizaram um trabalho sobre a interação de adesivos dentinários e superfícies de esmalte clareadas com peróxido de carbamida a 10\%. Em uma primeira fase, empregando 10 incisivos humanos, os pesquisadores avaliaram a concentração de oxigênio em diferentes regiões e profundidades da superfície vestibular dos dentes, através de Espectroscopia de Energia Dispersiva. Num segundo momento os autores avaliaram, usando-se de 15 molares humanos e MEV, as alterações morfológicas a partir da interação de diferentes adesivos dentinários. Após o clareamento das superfícies de esmalte com Opalescence (peróxido de carbamida a 10\%) por $4 \mathrm{~h}$ diárias durante 7 dias, empregou-se para esta segunda fase, Prime \& Bond 2.1 (adesivo dentinário à base de acetona), Syntac Single-Component (à base de água) e Scothbond Multi-Purpose Adhesive (controle).

Os resultados não mostraram diferenças estatisticamente significantes entre os esmaltes clareado e não clareado assim como entre as várias regiões e profundidades avaliadas. No entanto, verificou-se a tendência de menor acúmulo de oxigênio no terço incisal. Por outro lado, de uma forma geral, as concentrações de cálcio e fósforo eram significantemente menores nos dentes clareados quando comparados aos dentes não clareados. Verificaram que o clareamento causou alterações 
morfológicas na maior parte dos cristais de esmalte superficiais. Alguns cristais alterados exibiam núcleos eletroluscentes e espessura reduzida do material em torno dos mesmos.

Os autores, a partir dos resultados obtidos, sugerem que a redução na força de união entre o esmalte clareado e as restaurações de resina composta, pode não estar relacionada à inibição da polimerização da resina em função do acúmulo de oxigênio no interior da estrutura do esmalte como sugerem outros pesquisadores. Segundo os autores, do ponto de vista clínico, as alterações de proteínas e minerais constituintes das camadas superficiais do esmalte poderiam ser, mais provavelmente, as responsáveis pela perda da força de união entre a superfície de esmalte clareada e o material restaurador contrariamente ao que sugerem alguns trabalhos que atribuem ao oxigênio residual a responsabilidade por este efeito adverso. Portanto, recomendam ou o adiamento da restauração pós clareamento ou o uso de adesivos com solvente altamente voláteis.

Rotstein et al., em 1992a, investigaram o efeito de agentes clareadores nas composições inorgânicas da dentina e do cemento humanos pulverizados e imersos isoladamente em peróxido de hidrogênio a $30 \%$, peróxido de hidrogênio a $3 \%$, perborato de sódio a $2 \%$ e peróxido de hidrogênio a $30 \%$, perborato de sódio a $2 \%$ e peróxido de hidrogênio a $3 \%$, perborato de sódio a $2 \%$ e água bidestilada ou água bidestilada (controle), por períodos de $15 \mathrm{~min} ., 1 \mathrm{~h}, 24 \mathrm{~h}$ e $72 \mathrm{~h}$ simulando condições clínicas. A proposta deste estudo foi examinar o efeito dos diferentes agentes clareadores sobre a solubilidade e porcentagem dos componentes 
inorgânicos da dentina e do cemento humanos quando expostos aos agentes clareadores. O cemento, devido a sua maior permeabilidade, mostrou-se mais solúvel que a dentina e em todos os grupos verificou-se uma solubilidade gradualmente progressiva. No entanto não evidenciou-se diferença na percentagem de material inorgânico tanto da dentina como do cemento quando comparados os grupos do peróxido de hidrogênio $30 \%$ com o grupo do perborato de sódio $2 \%$ em peróxido de hidrogênio $30 \%$ após 24 e 72h. Os autores concluíram que as alterações da estrutura química tanto da dentina como do cemento promovidas pelo peróxido de hidrogênio $30 \%$ podem tornar estes tecidos mais susceptíveis à reabsorção e uma vez que o perborato de sódio em água não tenha promovido alterações significantes, sugerem que o uso clínico deste último deva ser encorajado.

Canepa et al. (1993) avaliaram in vitro a ação do perborato de sódio associado ao peróxido de hidrogênio a $30 \%$ e calor sobre a microdureza da dentina. Para tanto utilizaram um incisivo central superior humano recém extraído cujo terço cervical de sua raiz foi seccionado em três partes obtendo-se destas 12 fragmentos de dentina. As leituras de microdureza (dureza Vickers) da dentina dos corpos de prova foram realizadas antes e após cada uma das 3 aplicações do agente clareador ativado por calor. Os autores concluíram que o perborato de sódio com peróxido de hidrogênio e calor diminuem a microdureza da dentina e que à medida em que se repete a aplicação do agente clareador tem-se um efeito somatório na diminuição da microdureza da dentina. 
Pesquisando os efeitos dos agentes clareadores sobre a microdureza do esmalte e da dentina humanos Lewistein et al. (1994) realizaram um trabalho empregando peróxido de hidrogênio a $30 \%$ e uma pasta de perborato de sódio misturado com peróxido de hidrogênio, a $37^{\circ} \mathrm{C}$ e $50^{\circ} \mathrm{C} \mathrm{em}$ intervalos de 5, 15 e 30min. Os valores de microdureza Vickers tanto da dentina como do esmalte foram estabelecidos antes e depois do tratamento com os agentes clareadores segundo a conveniência estabelecida em pesquisas anteriores.

Os resultados indicaram que o tratamento com peróxido de hidrogênio a $30 \%$ reduz a microdureza do esmalte após $15 \mathrm{~min}$. e da dentina após $5 \mathrm{~min}$. Os autores sugerem que este efeito estaria diretamente relacionado à alteração da substância orgânica, devido a denaturação de colágeno como referiu Lado et al. em 1983. Por outro lado os pesquisadores não verificaram alteração significativa na microdureza tanto do esmalte como da dentina após o tratamento com pasta de perborato de sódio e peróxido de hidrogênio. Atribuíram a este efeito a menor solubilidade das microestruturas dentais frente a pasta de perborato de sódio e peróxido de hidrogênio. Não encontrou-se diferença significante na microdureza para os materiais clareadores testados tanto a $37^{\circ} \mathrm{C}$ como $50^{\circ} \mathrm{C}$, embora acredite-se que o calor aumente a reatividade dos agentes clareadores. Sugerem que altas concentrações de peróxido de hidrogênio para a proposta de clareamento devem ser limitadas e quando indicadas o perborato de sódio deve ser eleito como tratamento de escolha. 
Heling et al, 1995, realizaram um experimento para verificar a permeabilidade dentinária ao Streptococcus faecalis, marcador biológico, após o emprego de substâncias clareadoras (peróxido de hidrogênio a 30\%, peróxido de hidrogênio a $30 \%$ mais perborato de sódio, perborato de sódio mais água destilada e água destilada sozinha como controle). Inicialmente, os agentes clareadores foram selados em 60 incisivos bovinos e estes foram incubados a $37^{\circ} \mathrm{C}$ por 7,14 e 21 dias. Em seguida, após a remoção do agente clareador e esterilização com gás óxido de etileno, as amostras foram incubadas a $37^{\circ} \mathrm{C}$ em meio de cultura de Streptococcus faecalis por 14 dias. Então, preparam-se cortes histológicos e a penetração máxima bacteriana para cada grupo experimental foi medida usando-se um sistema morfométrico computadorizado. A análise estatística dos resultados revelou que os dentes tratados com o peróxido de hidrogênio a $30 \%$, tanto sozinho como em combinação com perborato de sódio, foram significativamente mais permeáveis ao Streptococcus faecalis do que aqueles tratados com perborato de sódio misturado com água. Os autores concluíram que os agentes clareadores contendo peróxido de hidrogênio em altas concentrações podem aumentar a penetração bacteriana através dos canalículos dentinários em razão da gama de alterações microestruturais que produzem.

Usando MEV e Espectrofometria de Energia Dispersiva, Rotstein et al. (1995) realizaram um trabalho com 90 amostras de restaurações de IRM (Classe III) verificando as alterações da morfologia da superfície bem como os níveis de óxido de zinco das mesmas frente ao uso de peróxido de 
hidrogênio a $10 \%$ e do peróxido de carbamida a 10\%, ambos com $\mathrm{pH} 6,5$. Concluíram que ambos os agentes clareadores empregados no experimento alteraram tanto a morfologia da superfície como os níveis de óxido de zinco do das restaurações de IRM mas sob modos de ação diferentes. A análise microscópica do grupo do peróxido de carbamida revelou uma superfície granular com áreas cristalinas bem definidas enquanto no grupo do peróxido de hidrogênio numerosas rachaduras da superfície das restaurações foram encontradas.

Rotstein et al., em 1996, submetendo hemisecções longitudinais de 21 premolares humanos recém extraídos com finalidade ortodôntica à imersão em 6 diferentes substâncias clareadoras realizaram a análise microscópica e histoquímica dos níveis de cálcio, fósforo, enxofre e potássio do esmalte, dentina e cemento. Testaram a ação clareadora do peróxido de hidrogênio a $30 \%$, peróxido de carbamida a $10 \%$, perborato de sódio, NuSmile, Opalescence e do DentlBright. Observaram uma diminuição dos níveis destes elementos químicos nos referidos tecidos dentais quando tais estruturas estiveram expostas à ação química dos agentes oxidantes.

O cálcio e o fósforo estão presentes nos cristais de hidroxiapatita, a principal unidade estrutural dos tecidos duros dentais. Mudanças na proporção $\mathrm{Ca} / \mathrm{P}$ indicam alterações nos componentes inorgânicos da hidroxiapatita. Em geral, diminuição nesta proporção são mais significativas no cemento e na dentina que no esmalte, provavelmente devido à diferenças na composição orgânica e inorgânica destes tecidos. O peróxido de hidrogênio foi o único material que reduziu significativamente a proporção de 
$\mathrm{Ca} / \mathrm{P}$ em todos estes tecidos. O peróxido de carbamida e o Opalescence reduziram significativamente a proporção de $\mathrm{Ca} / \mathrm{P}$ somente na dentina e cemento. Embora ambos tenham promovido redução da proporção $\mathrm{Ca} / \mathrm{P}$ tanto na dentina como no cemento, o DentlBright reduziu a proporção de $\mathrm{Ca} / \mathrm{P}$ na dentina enquanto que o $\mathrm{Nu}$ Smile reduziu a proporção de $\mathrm{Ca} / \mathrm{P}$ no cemento. Foi interessante observar que todos os géis clareadores testados neste trabalho reduziram a proporção de $\mathrm{Ca} / \mathrm{P}$ tanto na dentina como no cemento embora a concentração de peróxido de carbamida variasse de 10 a $15 \%$. Isto indica que outras substâncias que compõem estes produtos disponíveis comercialmente podem também desempenhar um papel no dano dos tecidos dentais, uma hipótese que merece ser melhor investigada.

As alterações dos níveis de enxofre, um marcador de proteoglicanas presente na matriz de tecidos duros, pode indicar danos na composição da matriz orgânica dos tecidos duros dentais. Dessa forma o cemento radicular é mais seriamente afetado pela mudança dos níveis de enxofre após o clareamento, o que se pode atribuir a maior concentração de componentes orgânicos neste tecido. De uma forma geral observaram-se variações nos níveis de potássio em todos os tecidos mas as diminuições foram mais freqüentes na dentina, principalmente após o tratamento clareador com peróxido de carbamida.

Os autores concluíram que uma vez que tais agentes podem adversamente afetar os tecidos dentais duros devem, portanto, serem usados com cautela. 
Seguindo a mesma linha de pesquisa Zalkind et al. (1996) analisaram as alterações morfológicas da superfície do esmalte, dentina e cemento humanos após o clareamento dental através de MEV utilizando os mesmos agentes clareadores testados no trabalho acima citado, i.e. peróxido de hidrogênio a $30 \%$, peróxido de carbamida a 10\%, perborato de sódio, Nu Smile, Opalescence e DentlBright. Para tanto os autores utilizaram 18 premolares humanos extraídos por razões ortodônticas que foram seccionados longitudinalmente no sentido vestíbulolingual obtendo-se, dessa forma, dois segmentos iguais cujo cemento foi removido usando-se disco de borracha abrasiva. Os seis grupos experimentais receberam o seguintes tratamentos clareadores: solução aquosa de peróxido de hidrogênio a $30 \%$, solução aquosa de peróxido de carbamida a 10\%, pasta de perborato de sódio e água e os seguintes agentes clareadores Nu Smile, Opalescence e DentlBright, comercialmente disponíveis em forma de gel. O tratamento consistiu na inclusão dos espécimes nos respectivos materiais testados por 7 dias e subsequente observação da morfologia superficial usando-se MEV. Os resultados mostraram alterações morfológicas tanto do esmalte como da dentina e do cemento em decorrência do uso da maioria dos agentes clareadores e estas foram classificadas em suaves, moderadas e severas. No esmalte o DentlBright causou as alterações mais severas, na forma de extenso achatamento e porosidade, em relação aos outros agentes clareadores testados. Ainda com relação ao esmalte o perborato de sódio causou um discreto achatamento da superfície. Na dentina o peróxido de hidrogênio causou as alterações mais severas tornando-as ásperas e com a 
aparência de superfície condicionada por ácido. Os espécimes tratados com Nu Smile, perborato de sódio e Opalescence não mostraram alterações e comportaram-se similarmente aos controles. No cemento a maioria dos agentes clareadores causou alterações morfológicas extensas e os espécimes tratados com peróxido de hidrogênio, peróxido de carbamida, Nu Smile e Dent|Bright mostraram múltitplas irregularidades e superfície fragmentada. Dessa forma, os autores concluíram que os materiais clareadores podem adversamente afetar a morfologia da superfície dos tecidos duros dentais e que, portanto, devem ser usados com cautela.

Barkhordar et al. (1997) analisando o efeito do clareamento de dentes despolpados sobre a microinfiltração de restaurações de resina composta realizou um trabalho empregando 36 incisivos humanos extraídos hígidos que foram divididos em 4 grupos de 9 dentes cada. No grupo controle realizou-se apenas a cirurgia de acesso e preenchimento da cavidade com uma bolinha de algodão seca por 7 dias. No segundo grupo o tratamento clareador consistiu no preenchimento da câmara coronária com uma pasta de perborato de sódio e peróxido de hidrogênio a 30\% por 2 dias. No terceiro grupo experimental a mesma pasta permaneceu no interior da câmara coronária por 4 dias. No quarto e último grupo a pasta foi mantida por 7 dias. Ao final do clareamento realizou-se a restauração das amostras usando-se o adesivo dentinário Scothbond MultiPurpose (3M Dental) e a resina composta Silux Plus (3M Dental). Após termociclagem as amostras tiveram suas raízes impermeabilizadas com verniz de unha e suas coroas imersas em corante. Posteriormente os dentes foram seccionados longitudinalmente procedendo- 
se à mensuração da profundidade de penetração do corante. Os resultados deste trabalho mostraram que o peróxido de hidrogênio com o perborato de sódio tem um efeito adverso sobre o selamento ao nível da interface dente restauração. Observou-se um efeito mínimo do material clareador sobre o selamento marginal dentro dos dois primeiros dias e um efeito significativo após 4 a 7 dias de clareamento. Segundo os autores o trabalho permite concluir que o clareamento não deve ser realizado por um período que exceda 2 dias e que deve ser tentada a completa eliminação de possíveis traços do material clareador. Por outro lado sugerem que a restauração com adesivo dentinário e resina composta não deve ser realizada imediatamente após o tratamento clareador, mas 2 dias após sua conclusão, para minimizar os efeitos do agente clareador sobre as propriedades de união da resina composta. Discutem que o papel de uma enzima com a função de remoção do peróxido de hidrogênio residual, não eliminado durante as lavagens, é uma questão que merece melhor atenção e que portanto deve ser investigada.

Entre 1997 e 1998, Crews et al. analisaram o efeito de 3 produtos clareadores - Brite Smile (Bright Smile Systems, Inc., Birmingham, AL), tendo como ingrediente ativo peróxido de hidrogênio a 10\%, Nu-Smile (M \& M Innovations, Brunswick, GA), com ingrediente ativo de peróxido de carbamida a $15 \%$ e Rembrandt Lighten (Dent-Mat, Santa Maria-CA), com ingrediente ativo de peróxido de carbamida a 10\% e carbopol - sobre a composição química do esmalte de dentes recém extraídos empregando Espectroscopia de Raios-x de Energia Dispersiva. Relataram um aumento 
dos níveis de cálcio e fósforo, após a aplicação do agente clareador, nos três grupos experimentais testados.

Embora os autores tenham trabalhado com os agentes clareadores mais comumente usados no branqueamento de dentes vitais, em que se empregam substâncias menos concentradas e supostamente menos nocivas, encontraram efeitos similares aos do clareamento de dentes não vitais.

Os autores relataram um aumento significativamente maior dos níveis de Ca e P quando do emprego do Rembrandt Lighten em relação aos outros dois agentes clareadores testados. Supõem que o carbopol (polímero mucoadesivo) do clareador Rembrandt (peróxido de carbamida a 10\%, equivalente a peróxido de hidrogênio a $3 \%$ e uréia a $7 \%$ ), teria promovido um contato mais íntimo do peróxido de carbamida com o esmalte potencializando sua ação.

2.5.2 Diminuição da resistência à fratura dos dentes tratados endodondicamente associada ao clareamento

Francischone et al. (1986) analisando a resistência à fratura de 100 premolares humanos extraídos despolpados e clareados com pasta de peróxido de hidrogênio 100 volumes e perborato de sódio com ou sem a aplicação de calor, comparando-os com controles hígidos, concluíram que além da perda clinicamente significativa da resistência em função da 
abertura coronária quando comparada ao dente hígido, que os agentes químicos e térmicos usados para o clareamento de dentes tratados endodonticamente diminuem significativamente a resistência destes à fratura.

Com o propósito de verificar a perda de resistência do dente provocada pelo clareamento dental, utilizando a técnica proposta por Nuttting \& Poe em 1963, Morares et al. (1991), submeteram 70 incisivos centrais superiores à cargas axiais de compressão em uma Máquina de Ensaios Universal, até que ocorresse a fratura do dente, registrando-se os valores das forças em unidades kgf. Os dentes foram agrupados a cada 10 espécimes da seguinte maneira: Grupo I: dentes hígidos (controle), Grupo II: abertura coronária, Grupo III: gutta-percha e IRM, Grupo IV: agentes químicos sem calor (1 sessão), Grupo V: agentes químicos com calor (1 sessão), Grupo VI: agentes químicos sem calor (2 sessões) e Grupo VII: agentes químicos com calor (2 sessões). Concluíram serem seus achados discordantes dos verificados por Francischone et al. (1986), de que os agentes químicos não enfraquecem o dente, uma vez terem sido empregados os mesmos agentes clareadores e térmicos. Ressaltam que essa diferença se deva ao fato de que o calor aplicado na câmara pulpar foi de forma branda, ou seja, aqueceram o calcador apenas duas vezes para que a pasta se tornasse mais fluída de modo a aumentar o desprendimento de oxigênio. Discutem, inclusive, que devido ao potencial cáustico do superoxol, um número maior de sessões possa vir a enfraquecer o dente. 
2.5.3 Reabsorção Radicular Cervical Externa em dentes tratados endodondicamente associada ao clareamento

Harrington \& Natkin em 1979 relataram 4 casos clínicos de pacientes portadores de dentes tratados endodonticamente, traumatizados e apresentando reabsorção radicular externa. As radiografias periapicais realizadas antes dos procedimentos de clareamento não evidenciaram quaisquer radioluscências ou rarefações radiculares cervicais. Por outro lado as radiografias realizadas após o tratamento clareador mostraram diferenças dramáticas na aparência cervical. As evidências não sugeriram processos reabsortivos como conseqüência direta dos traumatismos relatados pelos pacientes. Segundo os autores, embora não se possa estabelecer uma relação direta de causa-efeito entre clareamento e reabsorção radicular externa os casos relatados sugerem-na fortemente como conseqüência, provavelmente, da difusão do agente clareador caústico em direção ao ligamento periodontal.

Preocupado com o correto estabelecimento do diagnóstico Trope, em 1997, descreve a reabsorção radicular cervical como uma reabsorção radicular inflamatória externa que surge imediatamente abaixo do nível de inserção do epitélio juncional, ainda de etiopatogenia não totalmente compreendida, embora muitas teorias tenham sido apresentadas. De natureza progressiva, clinicamente assintomática, radiograficamente variável, histologicamente de aspecto idêntico a outras reabsorções radiculares inflamatórias é facilmente confundida com reabsorção radicular 
interna. O autor relaciona a etiologia da reabsorção radicular cervical a movimentos ortodônticos, cirurgias ortognáticas, tratamento periodontal, clareamento de dentes não vitais ou traumatizados que promovam o desarranjo do epitélio juncional e possível infecção da região tornando-a suscetível à ação de células clásticas. Ainda, teoria alternativa advoga que os procedimentos acima referidos alteram a proporção dos componentes orgânicos e inorgânicos do cemento induzindo consequentemente resposta inflamatória e ou imunológica.

Heithersay, 1999, analisando fatores potenciais na predisposição ao surgimento de reabsorção cervical invasiva avalia 257 dentes de um grupo de 222 pacientes portadores de reabsorção cervical em diferentes graus. 0 exame clínico (anamnese e exame físico) considerou como fatores predisponentes o traumatismo dentário, clareamento dental, cirurgia ao nível da junção amelo-cementária, tratamento ortodôntico, raspagem e planificação corono-radicular, bruxismo, erupção tardia, defeitos de formação e restaurações. O grau de reabsorção segundo sua extensão foi classificado em Classe 1, Classe 2, Classe 3 e Classe 4. Dos fatores predisponentes identificados, o tratamento ortodôntico era o fator isolado mais comum, seguido do traumatismo dentário e do clareamento dental. Os achados sugerem uma forte associação entre reabsorção cervical invasiva e tratamento ortodôntico, traumatismo dentário e clareamento intracoronário de forma isolada ou combinados. Dessa forma o autor atenta para que os clínicos estejam atentos para o fato de que a reabsorção cervical invasiva pode surgir subseqüentemente à ocorrência dos eventos acima referidos. 
Paralelamente sugere a realização de radiografias periódicas nos casos considerados de risco.

Cvek \& Lindvall realizaram em 1985 um trabalho retrospectivo para o qual selecionaram 11 incisivos superiores de 9 pacientes que receberam tratamento endodôntico no Instituto Eastman no período entre 1959 e 1965 e que apresentavam reabsorção radicular externa que poderia estar relacionada com clareamento dental. Dez destes dentes apresentavam histórico de traumatismo na forma de luxação ou sub luxação e em um caso o dente recebeu tratamento de canal em razão exclusivamente de pulpite induzida por cárie. A média de idade dos pacientes variava entre 11 e 16 anos. Em média os dentes traumatizados foram clareados 48 meses após o traumatismo. O clareamento foi realizado empregando-se peróxido de hidrogênio a $30 \%$ e uma lâmpada como fonte de calor. Em um caso o paciente retornou 6 semanas após a conclusão do tratamento clareador apresentando dor, mobilidade e extensa radioluscência radicular cervical. Todos os outros dentes apresentaram reabsorção radicular cervical detectadas no primeiro controle radiográfico realizado entre 6 e 12 meses após a conclusão do tratamento clareador entre os quais detectou-se reabsorção progressiva e anquilose. Segundo os autores existem razões para se acreditar que o efeito cáustico do peróxido de hidrogênio pode criar condições favoráveis ao aparecimento da anquilose.

Friedmam et al, 1988, realizaram um trabalho de prospecção avaliando a incidência de reabsorção radicular externa e os resultados estéticos de 58 dentes tratados endodonticamente e clareados durante um 
período de 1 a 8 anos após a conclusão do tratamento. Encontraram reabsorção radicular externa em $6,9 \%$ dos casos sem que nenhum dos pacientes relatasse histórico de traumatismo dental antes ou após o tratamento. Quanto aos resultados estéticos o clareamento foi considerado bem sucedido em apenas $50 \%$ dos casos, aceitável em $29 \%$ e falho em $21 \%$. Estes resultados aludem para o uso indiscriminado dos agentes clareadores e enfatizam a importância das medidas de prevenção assim como o acompanhamento pós-operatório de dentes tratados endodonticamente e clareados. Sugerem que a acidifiação da estrutura radicular possa atuar como um fator predisponente da atividade osteoclástica que poderia resultar em reabsorção radicular externa.

Discutem a questão do nível de corte do material obturador e sugerem a confecção de uma barreira protetora. No entanto nos casos em que se fizer necessário que este limite esteja apicalmente além da aderência epitelial sugerem os autores que o espaço seja preenchido com hidróxido de cálcio para fins de alcalinização do meio após o clareamento. A difusão dos agentes clareadores através da dentina depende diretamente da sua permeabilidade.

Rotstein et al. (1991a) observaram que temperaturas mais altas empregadas no tratamento clareador, usando-se a técnica termocatalítica, aumentaram a penetração radicular do peróxido de hidrogênio. Neste estudo os pesquisadores verificaram uma relação direta do aumento da penetração radicular do peróxido de hidrogênio a $30 \%$ em função do tempo e da temperatura empregadas na técnica clareadora. Relataram que 
temperaturas mais altas aumentam a penetração radicular do peróxido de hidrogênio. Quando do aumento de $24^{\circ} \mathrm{C}$ para $37^{\circ} \mathrm{C}$ houve uma penetração dobrada da quantidade peróxido de hidrogênio e este aumento foi menos significante quando a temperatura foi aumentada de $37^{\circ} \mathrm{C}$ para $47^{\circ} \mathrm{C}$. No entanto não verificou-se aumento significativo de penetração do agente clareador após um período de $5 \mathrm{~min}$. a qualquer temperatura testada. Segundo os autores o tempo de clareamento desempenhou um importante papel na difusão do peróxido de hidrogênio através da dentina de tal forma que a expansão dos túbulos dentinários é dependente do tempo sendo mínima durante os primeiros $5 \mathrm{~min}$. Considerando outros trabalhos levantam a questão de que o uso de calor em combinação com o peróxido de hidrogênio a 30 \% tem sido apontado como um fator iniciador da reabsorção radicular pós clareamento. Também consideraram que tanto o peróxido de hidrogênio como o calor empregados isoladamente podem causar menos danos teciduais. Recomendam minimizar o uso do calor e a duração das sessões de clareamento.

Rotstein et al. (1991b) discutiram a respeito da relação entre os defeitos do cemento e a penetração de peróxido de hidrogênio a $30 \%$ durante o clareamento. Os autores concluíram que houve penetração do peróxido de hidrogênio em todos os dentes testados com ou sem defeitos cementários. A penetração radicular do peróxido de hidrogênio foi significantemente maior nos dentes que apresentavam defeitos ao nível da junção amelo-cementário quando comparados com dentes com superfície radicular íntegra. Para os investigadores a permeabilidade dentinária e a 
integridade cementária desempenham papel chave na determinação da penetração do peróxido de hidrogênio assim como, por outro lado, o aumento clínico da permeabilidade dentinária pode promover uma maior difusão dos agentes clareadores em direção aos tecidos periodontais.

Segundo estes autores a ausência de cemento pode dar-se em função de razões tanto de ordem morfológica como patológicas. Do ponto de vista da morfologia dental, os trabalhos tradicionais mostram que a junção amelo-cementária pode variar entre os diferentes grupos dentais na mesma pessoa, revelando que a exposição dentinária pode ocorrer em $18 \%$ dos casos. No que respeita às iatrogenias, intervenções periodontais assim como tratamentos ortodônticos podem acarretar condições patológicas que consistem na reabsorção cementária e ou dentinária.

Os autores recomendam a proteção do término da obturação de gutta-percha com uma base isolante, durante a realização dos procedimentos intracoronários do clareamento, com vistas à diminuição da penetração do agente clareador.

Os pesquisadores especulam os mecanismos de reabsorção radicular relacionada ao tratamento clareador considerados por outros autores: (1) os agentes clareadores denaturam a dentina e esta possa atuar como corpo estranho e desencadeador de resposta inflamatória ao nível do ligamento periodontal (Lado et al., 1983); (2) a difusão do agente clareador através dos túbulos dentinários para o ligamento periodontal cervical desencadeia um processo reabsortivo inflamatório (Harrington \& Natkin, 1979); (3) após a irritação dos tecidos periodontais pelo agente clareador, a colonização 
bacteriana (bactérias originadas ou do tecido pulpar ou do espaço periodontal) dos túbulos vazios pode causar inflamação dos tecidos circunvizinhos bem como reabsorção radicular progressiva (Cvek \& Lindvall, 1985).

Os autores acreditam que a injúria inicial promovida pelo agente clareador em relação aos tecidos periodontais podem causar necrose do ligamento periodontal e conseqüente desajuste funcional deste tecido. Por outro lado radicais livres de oxigênio podem ter efeito tóxico tanto ao nível celular como tecidual. Consideram as conclusões de Ramp et al. (1987), segundo os quais pequenas quantidades de peróxido de hidrogênio inibem a síntese de colágeno e o metabolismo da glicose in vitro, assim como a diminuição do peso ósseo e da atividade da fosfatase alcalina.

Segundo Rotstein \& Friedman, 1991, a reabsorção radicular externa é uma decorrência ocasional do clareamento de dentes tratados endodonticamente, usando-se tanto a técnica Walking Bleach como a técnica Termocatalítica. De acordo com os autores o relato de Kehoe (1987) de que uma mistura espessa de perborato de sódio e superoxol era ácida e promovia uma redução do $\mathrm{pH}$ da superfície radicular externa e do ligamento periodontal predispondo à reabsorção radicular externa contrastava com os achados de Fuss et al. (1989) que registraram pH alcalino para uma pasta confeccionada de perborato de sódio monohidratado e superoxol. Dessa forma, analisaram a variação de $\mathrm{pH}$ entre os materiais usados para o tratamento clareador de dentes tratados endodonticamente. Para tal experimento os autores empregaram 20 frascos plásticos contendo 
diferentes concentrações de pastas clareadoras e que consistiam ou da mistura de perborato de sódio e peróxido de hidrogênio a $30 \%$ ou perborato de sódio e água bidestilada. As medidas de $\mathrm{pH}$ foram realizadas após 1, 3 e 24h, seguidas por medidas posteriores em 2, 7 e 14 dias. Os autores concluem que a reabsorção radicular externa não resulta de uma variação de $\mathrm{pH}$ mas, contrariamente, de um dano direto das estruturas que circundam a raiz.

Rotstein et al. (1992b) realizaram um trabalho avaliando o efeito do revestimento da superfície radicular externa com polímero de etil celulose e copolímero ácido metacrílico na penetração do peróxido de hidrogênio durante o clareamento. Vinte e dois premolares unirradiculares tiveram o cemento situado ao nível da junção amelo-cementária removido mecanicamente, tratados endodonticamente e clareados. A penetração do peróxido de hidrogênio a $30 \%$ foi medida antes do recobrimento cervical externo dos dentes e após a aplicação de 1 a 3 camadas de polímero de etil celulose ou 3 camadas de copolímero ácido metacrílico. Todos os registros anteriores ao recobrimento cervical externo mostraram difusão de peróxido de hidrogênio para o meio extrarradicular. Verificou-se uma diminuição crescente da quantidade de peróxido difundido para o meio extrarradicular com os dentes recobertos por $2(38 \%)$ e $3(85 \%)$ camadas de polímero de etil celulose. O copolímero de ácido metacrílico, em 3 camadas, reduziu a penetração do peróxido de hidrogênio em $83 \%$. Conclui-se que a aplicação de polímero etil celulose ou de copolímero de ácido metacrílico nas 
superfícies radiculares cervicais expostas pode efetivamente prevenir a difusão extrarradicular dos agentes oxidantes durante o clareamento.

2.5.4 Redução da adesividade dos materiais restauradores em dentes clareados

A partir da década de oitenta surgiram alguns trabalhos na literatura científica relacionada ao tratamento restaurador de dentes tratados endodonticamente e clareados e que relatavam diminuição da adesividade dos adesivos dentinários e, consequentemente, do material restaurador como decorrência do emprego das substâncias oxidantes do tratamento clareador.

Avaliando o efeito de uma solução concentrada de peróxido de hidrogênio a $35 \%$ sobre a morfologia da superfície de fragmentos de dentina humana usando MEV, Titley et al. (1988a) submeteram 28 espécimes à imersão em peróxido de hidrogênio a $35 \%$ isoladamente ou em combinação com condicionamento com ácido ortofosfórico a 37\%, comparando-os com controles em solução salina em períodos de 1, 3, 5, 10, 20, 30 e 60min. Os espécimes foram obtidos através da secção transversal de premolares humanos extraídos por razão ortodôntica de tal forma que se obtivessem discos de $1 \mathrm{~mm}$ de espessura que novamente foram subdivididos em quatro partes. 
O grupo I foi imerso em peróxido de hidrogênio ou solução salina nos períodos determinados. No grupo II os espécimes foram imersos em solução de peróxido de hidrogênio a $35 \%$ ou solução salina, nos tempos designados, e então condicionados com ácido ortofosfórico a $37 \%$ por 60 s. No grupo III os espécimes foram condicionados com ácido ortofosfórico a 37\% e então imersos em peróxido de hidrogênio a $35 \%$ ou solução salina nos tempos experimentais. A análise microscópica mostrou precipitado amorfo após 20 min. de imersão em solução de peróxido de hidrogênio a 35\%; depósito granular fino e dentina limpa após imersão em peróxido de hidrogênio e condicionamento ácido, sucessivamente, e remoção do magma dentinário e alargamento dos orifícios de entrada dos túbulos dentinários, com menor acúmulo de precipitado em relação aos outros, quando do condicionamento ácido e subsequente imersão em peróxido de hidrogênio. Os autores não verificaram o mesmo grau de alteração na morfologia da superfície dentinária como encontraram em relação ao esmalte em outros trabalhos que realizaram anteriormente, o que provavelmente deva-se aos diferentes padrões de mineralização dos tecidos em questão. Os resultados deste trabalho confirmam a habilidade de ácidos fracos em remover magma dentinário e alargar os orifícios dos túbulos dentinários após 60 s de exposição e dessa forma providenciar uma dentina melhor penetrada pelos agentes clareadores e rapidamente restaurada pela resina composta. Nos espécimes condicionados por ácido fosfórico e subseqüentemente imersos por período prolongado em peróxido de hidrogênio o precipitado observado 
poderia ter surgido da interação entre o agente clareador com o colágeno da superfície dentinária.

Os autores especulam o fato de que o condicionamento ácido do esmalte pudesse ser realizado após o clareamento na medida que uma superfície mais porosa fosse mais adequada para fins de adesividade.

Titley et al. (1988b) pesquisando as alterações microestruturais ao nível de esmalte decorrentes do clareamento, avaliaram com Microscopia Eletrônica de Varredura secções transversais de premolares humanos recém extraídos após imersão em solução concentrada de peróxido de hidrogênio a 35\%. Neste experimento, no primeiro grupo as secções foram imersas somente em solução concentrada de peróxido de hidrogênio a 35\%, no segundo grupo as secções foram condicionadas com Ácido Fosfórico a $37 \%$ antes da imersão em solução de peróxido de hidrogênio a 35\% e no terceiro grupo, as secções foram imersas em peróxido de hidrogênio a 35\% e posteriormente condicionadas por ácido fosfórico a $37 \%$. Os controles foram imersos em solução salina e todas as amostras foram avaliadas por períodos que variaram de 1 a $60 \mathrm{~min}$. Os autores concluíram que o efeito prolongado do peróxido de hidrogênio efetivamente altera a superfície do dente o que consiste no aumento da porosidade da superfície e formação de um precipitado, assim como não é possível afirmar se tais características tornam essa superfície mais ou menos adequadas com relação à adesividade dos materiais restauradores.

Titley et al. (1988c) pesquisando a adesividade das resinas compostas em relação ao esmalte bovino clareado e não clareado, 
realizaram um trabalho em que aplicaram agente clareador sobre a superfície vestibular de 256 dentes incisivos. Desta forma, constituíram quatro grupos experimentais a saber: (1) Grupo I: imersão em solução de peróxido de hidrogênio a $35 \%$ por $60 \mathrm{~min}$. e subsequente condicionamento com gel de ácido fosfórico a 37\% por 60s.; (2) Grupo II: imersão em solução de soro fisiológico e aplicação de gel de ácido fosfórico a 37\% por 60s; (3) Grupo III: condicionamento com gel de Ácido Fosfórico a 37\% por 60s e imersão em solução de peróxido de hidrogênio a $35 \%$ por $60 \mathrm{~min}$. e (4) ataque ácido com gel de ácido fosfórico a 37\% e imersão em soro fisiológico por 60min.

Antes dos testes de tração e cisalhamento todos os espécimes foram armazenados em água a $37^{\circ} \mathrm{C}$ por 1 e 7 dias e em seguida as amostras foram avaliadas quanto ao tempo de armazenamento, tipo de resina composta empregada, ordem de realização do condicionamento ácido e tipo de teste.

Os resultados mostraram uma redução estatisticamente significativa da força de adesão nos espécimes clareados com peróxido de hidrogênio a $35 \%$ quando comparados com os tratados com solução de soro fisiológico. Verificou-se uma diferença estatisticamente significante, nos grupos tratados com soro fisiológico, quando da comparação entre os espécimes estocados em água por 7 dias com aqueles armazenados por 1 dia.

A ordem de condicionamento ácido foi estatisticamente significante, nos testes de tensão, para os subgrupos em que se empregou resina de 
pequenas partículas e em contrapartida a ordem do condicionamento ácido não influenciou os espécimes quando a resina de micropartícula foi usada.

Quanto aos testes de cisalhamento, a análise estatística indicou diferenças altamente significantes na força adesiva dos espécimes tratados com soro fisiológico em relação aos tratados com peróxido de hidrogênio. Esta significância foi mantida independentemente do tipo de resina, da ordem do condicionamento ácido e do tempo de armazenamento.

A MEV indicou que a redução da adesividade ocorreu primeiramente ao nível da interface resina-esmalte.

Titley et al. (1989) pesquisando a adesividade do cimento de ionômero de vidro em dentina bovina clareada (peróxido de hidrogênio a $35 \%$ ) e não clareada (solução salina), concluíram que houve uma redução altamente significante na força de união do cimento de ionômero de vidro à dentina exposta ao peróxido de hidrogênio quando comparada à solução salina. Verificaram ao MEV que nos espécimes testados houve uma falha na união do cimento à dentina sugerindo que o peróxido de hidrogênio residual tenha afetado a polimerização do ionômero de vidro. Segundo os autores o tratamento restaurador com ionômero de vidro de dentes que foram submetidos ao clareamento somente pode ser aconselhado criteriosamente.

Torneck et al., em 1990, realizaram um trabalho avaliando a influência do tempo de exposição ao peróxido de hidrogênio na adesividade da resina composta ao esmalte bovino clareado. 256 espécimes receberam quatro tipos diferentes de tratamento: no grupo 1 os dentes foram imersos em peróxido de hidrogênio por 5 e 30min.; no grupo 2 os dentes foram imersos 
em solução salina por 5 e 30min.; no grupo 3 as superfícies de esmalte foram condicionadas com ácido fosfórico a $37 \%$ antes da imersão em peróxido de hidrogênio por 5 e 30min. e no grupo 4 as superfícies de esmalte foram condicionadas com ácido fosfórico a $37 \%$ e imersas em solução salina por 5 e $30 \mathrm{~min}$. Cada superfície de esmalte recebeu a aplicação de resina composta usando-se um sistema de adesivo dentinário dual. Então, os espécimes foram submetidos aos testes de tensão e cisalhamento e um dente de cada grupo foi selecionado aleatoriamente para avaliação com MEV. Os autores observaram uma diminuição da força de união da resina composta quando a superfície de esmalte foi exposta ao peróxido de hidrogênio e que essa adesividade reduzida variava em função do tempo. A força de união independia se o condicionamento ácido era realizado antes ou depois da exposição ao peróxido de hidrogênio assim como do tempo de armazenamento em água. Microscopicamente observouse falha de união ao nível da interface resina-esmalte que se devia a alterações da resina composta devido supostamente à presença de peróxido de hidrogênio residual ou seus subprodutos na superfície de esmalte.

Avaliando a questão da adesividade de materiais restauradores em dentes submetidos ao tratamento clareador, Torneck et al, em 1991, realizaram um experimento em que dentes bovinos clareados e não clareados foram imersos em água bidestilada e então submetidos a testes de tração e cisalhamento. No primeiro grupo experimental as amostras foram submetidas à imersão em solução de peróxido de hidrogênio a $35 \%$ em intervalos de 5, 30 e 60min. e em seguida condicionadas com gel de 
ácido fosfórico a $37 \%$. No segundo grupo os espécimes foram imersos em solução salina por 5, 30 e 60min. e em seguida condicionados com ácido fosfórico a $37 \%$. No terceiro e quarto grupos os espécimes receberam condicionamento ácido previamente a imersão no agente clareador e em soro fisiológico respectivamente, nos períodos de 5, 30 e 60min.

Para os testes de tração e cisalhamento os autores confeccionaram cilindros de resina composta fotopolimerizada que foram colados nas superfícies vestibulares dos 192 dentes incisivos e utilizaram a Máquina Universal de Teste Instron (Canton-MA, USA) mod. TT.CM.

Os resultados revelaram uma diferença estatisticamente significante entre os grupos tratados com peróxido de hidrogênio em relação aos grupos controle. Segundo os autores os resultados deste trabalho apontam para o fato de que os efeitos deletérios do peróxido de hidrogênio sobre a adesividade da resina podem ser reversíveis e encurtados. Dessa forma sugerem que a exposição a saliva pode por um determinado período de tempo remover o peróxido de hidrogênio absorvido pelo esmalte e restabelecer ou, possivelmente melhorar, o potencial original de adesividade. Ainda, do ponto de vista metodológico, os testes de tração evidenciam melhor as diferenças entre os grupos experimentais no que respeita aos efeitos microestruturais dos agentes clareadores bem como ao efeito recuperador das forças de adesão como conseqüência da imersão em água.

Titley et al., em 1991, empregando MEV avaliaram a penetração e a estrutura dos tags ao nível da interface esmalte-resina em esmalte bovino clareado e não clareado. Nos espécimes controle observaram tags bem 
definidos e contíguos com a resina que estava uniformemente aderida à superfície de esmalte. Nos espécimes experimentais observaram grandes áreas da superfície de esmalte livres de resina e quando os tags estavam presentes, estes encontravam-se fragmentados, pobremente definidos e pouco profundos em relação aos espécimes controle. Tais alterações sugerem uma possível interação entre a resina e peróxido de hidrogênio residual na superfície do esmalte ou próximo dele.

Pesquisando a adesividade de materiais restauradores ao esmalte de incisivos bovinos sob a ação de forças de cisalhamento e análise microscópica, Titley et al. (1992), realizaram um estudo empregando gel de peróxido de carbamida a $10 \%$ variando $\mathrm{pH}(4,7$ e 7,2$)$ e tempo de exposição ao agente clareador ( 3 e 6 h). Esses dois níveis e pH foram selecionados para determinar se a adesividade ao esmalte poderia ser diferentemente afetada pelo uso de um produto neutro ou ácido. Com relação aos períodos de tempo escolhidos, os autores justificam que a média do período de contato das substâncias clareadoras de uso caseiro varia entre 5 e 6 h por noite. Dois grupos experimentais adicionais submetidos ao peróxido de carbamida a $10 \%(\mathrm{pH} 7,2)$ durante $6 \mathrm{~h}$ foram lavados com água destilada por 1 e 7 dias respectivamente. Concluídos os tempos teste, os corpos de prova confeccionados em resina composta Silux Plus (3M Canada Inc.) foram colados às superfícies vestibulares do esmalte e submetidos a ação de forças de cisalhamento utilizando-se uma Máquina Universal de Teste Instron (Modelo TT. CM, Canton,MA, USA). A análise estatística dos dados mostrou que as exposições do esmalte ao peróxido de carbamida a 10\% por 
um período e 3 ou $6 \mathrm{~h}$ resultou em uma redução estatisticamente significante na força de união da resina Silux ao esmalte bovino. A redução, entretanto, foi substancialmente menor quando comparada com os resultados de testes similares em que uma solução aquosa de peróxido de hidrogênio a $35 \%$ foi usada (Titley et al., 1988). Uma vez que os peróxidos de carbamida em base de glicerol são mais viscosos que as formas aquosas do peróxido de hidrogênio, a imersão em peróxido de carbamida em água foi realizada para determinar se sua adesividade poderia ser restabelecida. Os resultados mostraram que os dentes tratados com peróxido de carbamida em água por pelo menos um dia resultou em valores de força de cisalhamento iguais aos das amostras controle.

Em 1993 Titley et al., pesquisaram a adesividade das resinas compostas sobre a superfície de premolares humanos imersos em solução concentrada de peróxido de hidrogênio a $35 \%$. Foram utilizados neste experimento 15 premolares humanos hemiseccionados que receberam 3 diferentes tratamentos. No primeiro grupo experimental as secções foram imersas em solução de peróxido de hidrogênio a 35\% durante $60 \mathrm{~min}$., no segundo grupo as secções foram imersas em peróxido de hidrogênio a $35 \%$ durante 60min. e armazenadas em água destilada por um dia antes da aplicação da resina, e no terceiro grupo as secções foram imersas em solução salina por $60 \mathrm{~min}$.. Todos os espécimes foram armazenados em água destilada a $37^{\circ} \mathrm{C}$ antes do teste de cisalhamento. A análise estatística indicou que houve uma redução altamente significativa na resistência ao cisalhamento dos dentes que foram imersos em peróxido de hidrogênio 
quando se os comparou ao grupo de secções que foram imersas em solução salina por um dia antes de receberem a resina composta. Segundo os autores os espécimes tratados com peróxido de hidrogênio e armazenados em água por um dia antes da aplicação da resina recuperaram a adesividade mas não de uma forma significativa. Segundo os autores a análise sob MEV das amostras que falharam nos testes de cisalhamento sugerem que a presença de peróxido de hidrogênio teria inibido a polimerização da resina e consequentemente sua adesividade.

Em 1996, Fortuna avaliou a possível alteração na força de adesão por cisalhamento de resinas compostas fotopolimerizáveis aplicadas ao esmalte clareado com peróxido de carbamida a 10\% com carbopol em dentes vitalizados.

O autor concluiu que a força de cisalhamento necessária para o deslocamento das restaurações dos dentes clareados após o primeiro dia, findo o tratamento clareador, foi quantitativamente menor que a força aplicada nos dentes que não sofreram tratamento clareador. No entanto, a força de cisalhamento nos dentes que sofrearam clareamento foi menor no $1^{\circ}$ dia em relação ao $5^{\circ}$ e $10^{\circ}$ dias mas mantendo-se, praticamente, a mesma ao longo do período experimental. A pesquisa não permitiu estabelecer com precisão qual seria o momento adequado para a realização do tratamento restaurador, uma vez que a proposta do trabalho não foi a de determinar quando este efeito deletério cessaria.

O efeito do agente clareador sobre a força de união entre a resina composta e o esmalte clareado também foi avaliada por van der Vyver et al. 
(1997) que testaram um agente clareador comercialmente disponível, o Hi Lite (Shofu Dental Corporation), à base de peróxido de hidrogênio a $35 \%$ e foto ativado. Para esse experimento empregaram-se 80 dentes anteriores humanos recém extraídos e que foram distribuídos aleatoriamente em quatro grupos. O primeiro grupo serviu como controle e os demais foram clareados, condicionados com ácido maleico e pincelados com adesivo para receberem os respectivos corpos de prova de resina Z100 (3M Dental Products). O grupo 2 recebeu os corpos de prova logo após o clareamento enquanto que os grupos 3 e 4 os receberam após 1 e 2 semanas respectivamente.

Concluíram que o sistema clareador empregado reduziu a força adesiva do esmalte clareado e sugerem que o tratamento restaurador seja postergado por 2 semanas após a realização de qualquer procedimento clareador.

Em 1997, Silva e Souza Jr. \& Oliveira realizaram um trabalho pesquisando a resistência adesiva em esmalte de dentes clareados utilizando teste de cisalhamento. Para tanto empregaram 40 incisivos centrais e laterais inferiores íntegros e extraídos por razões periodontais e que foram divididos em quatro grupos, sendo 1 grupo controle. No Grupo I os dentes foram endodonticamente tratados, condicionados com gel de ácido fosfórico a 35\% e tiveram suas câmaras coronárias preenchidas com pasta formada de peróxido de hidrogênio a $35 \%$ e perborato de sódio. Em seguida foram imersos em solução salina por 5 dias a $37^{\circ} \mathrm{C}$. As trocas do material clareador foram realizadas por mais duas vezes em intervalos de cinco dias e decorridos 5 dias da última troca a câmara coronária foi 
preenchida com uma pasta de hidróxido de cálcio p.a. e água destilada por 10 dias, selada com IRM. No Grupo II os espécimes receberam algodão saturado com peróxido de hidrogênio a $30 \%$, tanto no interior da câmara coronária como na superfície vestibular do esmalte, ativado pelo calor através de um instrumento aquecido ao rubro. No Grupo III, os dentes receberam clareamento extracoronário empregando-se Opalescence (Ultradent Products), peróxido de carbamida a 10\%. No Grupo IV nenhum tratamento clareador foi realizado sendo este, então, considerado o grupo controle.

Em seguida os espécimes foram submetidos aos testes de adesividade através de testes de resistência ao cisalhamento e posteriormente dois dentes de cada grupo foram submetidos a MEV.

Os pesquisadores observaram padrões mais heterogêneos de dissolução do esmalte nos espécimes submetidos a ação do peróxido de carbamida a $10 \%$ por $30 \mathrm{~h}$, quando comparados ao esmalte condicionado apenas com ácido fosfórico a $35 \%$ em que notaram uma certa homogeneidade no padrão de condicionamento.

Concluíram que a resistência adesiva determinada por testes de cisalhamento ao esmalte tratado com diferentes técnicas de clareamento foi superior à resistência adesiva observada sobre o esmalte não tratado. Discutem ainda que não se pode afirmar categoricamente que a razão pela qual a resistência adesiva aumentou se deve à topografia mais detalhada do esmalte encontrada nos dentes tratados com soluções clareadoras, uma vez que apenas alguns espécimes foram preparados para MEV. Aludem também 
para o fato de que os testes adesivos realizados após 10 dias do final do tratamento clareador possam ter contribuído para o aumento da resistência adesiva.

Mathias publicou sua tese em 1998 a partir de um estudo comparativo in vitro sobre a resistência adesiva à dentina de molares decíduos, entre quatro materiais restauradores, por ensaio de tração. Para tanto, o pesquisador usou 20 molares decíduos humanos, com reabsorções radiculares fisiológicas, que foram divididos longitudinalmente ao meio no sentido mésio-distal. Então, cada uma das metades foi incluída em resina acrílica autopolimerizável transparente obtendo-se discos que eram lixados para exposição e planificação das superfícies oclusais. Cada um dos materiais restauradores comercialmente disponíveis constituiu um grupo experimental: (1) resina composta (Z100) e sistema de adesivo dentinário Scothbond Multi-adesão Plus; (2) resina composta modificada por poliácidos Dyract; (3) cimento de ionômero de vidro modificado por resina composta Vitremer e (4) cimento de ionômero de vidro do tipo convencional Shofu tipo II.

Todos os corpos de prova foram armazenados em meio úmido por $24 \mathrm{~h}$ a $37^{\circ} \mathrm{C}$, período após o qual foram submetidos aos testes de tração.

A análise do tipo de falha de adesividade foi realizada através da avaliação das superfícies dentinárias usando-se uma lupa com aumento de 20X. Segundo o aspecto visual da face de dentina de cada espécime as fraturas foram classificadas usando-se como critério a presença ou ausência de material restaurador na área de adesão das mesmas. Dessa forma, 
definiu-se como falha de (1) adesividade quando visualizava-se restos do material restaurador na área de adesão, de (2) coesividade quando não se visualizava restos do material restaurador na área de adesão e do tipo (3) misto (predominantemente adesiva ou predominantemente coesiva) quando apenas parte da área de adesão apresentava restos do material restaurador.

A análise estatística demonstrou que a resina composta sobre adesivo dentinário apresentou maior resistência adesiva que a resina composta modificada por poliácidos e que esta teve valores maiores que o ionômero de vidro modificado por resina composta e o cimento de ionômero de vidro convencional. $\mathrm{O}$ autor concluiu ainda que a resina composta e a resina composta modificada por poliácidos apresentaram um tipo de fratura predominantemente adesiva enquanto que o ionômero de vidro modificado por resina composta e o cimento de ionômero de vidro convencional apresentaram tipo de fratura predominantemente coesiva.

Spyrides et al. (2000) analisaram o efeito dos agentes clareadores sobre a adesividade da dentina utilizando 120 incisivos bovinos recém extraídos. Para tanto os pesquisadores constituíram 8 grupos experimentais, cada um composto de 15 espécimes. A adesividade à dentina foi avaliada tendo-se como critério básico o momento em que se deu a aplicação do material restaurador após a utilização dos seguintes agentes clareadores: (1) peróxido de hidrogênio a 35\% por 30 min.; (2) peróxido de carbamida a 35\% por 30min.; (3) peróxido de carbamida a $10 \%$ por 6 h e (4) grupo controle sem clareamento. Os resultados dos testes de cisalhamento mostraram diferenças estatisticamente significantes entre os grupos experimentais e o 
grupo controle. Os autores verificaram uma redução da força de adesão do material restaurador à dentina clareada imediatamente após o tratamento clareador estatisticamente significante e que variavam entre $71 \%$ e $76 \%$. Os maiores valores de força de adesão foram obtidos com os espécimes tratados com peróxido de hidrogênio $35 \%$ por $30 \mathrm{~min}$. Enquanto que os menores valores foram obtidos com o grupo de espécimes tratados com peróxido de carbamida a $10 \%$.

Aludem para as considerações de outros pesquisadores que referem a redução da adesividade tanto do esmalte como da dentina como conseqüência de alterações microestruturais destes tecidos em função da perda de íons cálcio mediante o tratamento clareador.

\subsubsection{Recidiva do manchamento}

Rotstein et al. (1993a) realizaram um experimento in vitro avaliando as perspectivas do tratamento clareador com perborato de sódio e para tanto empregaram pastas de perborato de sódio ora misturado com peróxido de hidrogênio a $3 \%$, peróxido de hidrogênio a $30 \%$ e finalmente água. Os pesquisadores produziram alterações cromáticas em coroas intactas de 47 dentes humanos extraídos empregando eritrócitos e estes foram tratadas com as referidas pastas clareadoras. Realizaram a análise cromatográfica através de fotografias pré-operatórias comparando-as com as obtidas em períodos de 3, 6 e 12 meses. Os autores observaram que todas as amostras 
mantiveram sua tonalidade nos períodos de 3 e 6 meses enquanto que no período de 1 ano $6,8 \%$ do total das amostras mostraram alguma regressão (escurecimento) de cor. Segundo os autores a inconsistência entre os resultados clínicos e os obtidos in vitro pode ocorrer por diversos fatores como a etiologia da descoloração, o ambiente no qual os dentes estão inseridos, a qualidade de selamento marginal ao nível da interface dentematerial restaurador e o tempo em que o dente permaneceu descolorido. A partir dos resultados do presente estudo parece que os resultados obtidos do clareamento com as três preparações com perborato de sódio são igualmente efetivos por um período de 1 ano. A eficácia do clareamento com perborato de sódio acrescido de peróxido de hidrogênio a $30 \%$ é reconhecida mas, no entanto, igual resultado pode ser alcançado sem o peróxido de hidrogênio através do aumento do número de tratamentos. Uma vez que o peróxido de hidrogênio esteja associado a reabsorção radicular externa os autores sugerem o emprego de uma pasta clareadora composta de perborato de sódio e água.

\subsubsection{Outros efeitos adversos}

Os agentes clareadores usados no clareamento dental de polpa viva, muito difundidos atualmente, também podem alterar a cor das resinas compostas na restauração dos dentes. Com o intuito de avaliar o comportamento dos agentes clareadores sobre a cor das resinas compostas 
Ramos et al. em 1999, realizaram um trabalho com o objetivo de avaliar a alteração de cor de 3 resinas compostas sob a ação do peróxido de carbamida a $10 \%$. Foram utilizadas as seguintes resinas: Degufill $\mathrm{H}$ (Degussa), Prodigy (Kerr) e Charisma (Kulzer). Os corpos de prova foram microfilmados e tiveram suas imagens digitalizadas pelo sistema Accucam, para análise comparativa por meio do programa Adobe Photoshop 4.0. Este programa quantifica a porcentagem de cor (pixels), analisando qualquer alteração na cor da superfície da resina composta, tanto clareamento como escurecimento.

Concluem que o peróxido de carbamida a $10 \%$ atuou nas diferentes marcas de resina composta, clareando-as embora esse clareamento tenha sido praticamente imperceptível ao olho humano, não ocasionando uma importante perda do resultado estético de uma restauração feita antes de um tratamento clareador. Os autores aconselham, inclusive, que se realize a troca das restaurações de resina composta após o clareamento dental, uma vez que o conjunto do sorriso, poderá apresentar alguma diferença entre a cor do esmalte e da resina composta de alguma restauração antiga, devido unicamente a uma alteração na cor do esmalte clareado. 
2.6 RESTAURAÇÃO DOS DENTES TRATADOS ENDODONTICAMENTE E CLAREADOS

Desde sua introdução através da patente do alemão Kulzer $\mathrm{GmbH}$ na década de cinqüenta a resina acrílica tem sido empregada de diversas formas na Odontologia com finalidades restauradoras e protéticas. Esta aplicabilidade tornou-se muito mais ampla com a criação do polímero BISGMA (Adaptic em 1969), de melhores propriedades mecânicas e que permaneceu disponível por mais de 30 anos, por Bowen no National Bureau of Standards, Gaithersburg, USA, na década de sessenta. Sobre o emprego das mais recentes formulações para restaurações tanto diretas como indiretas o autor considera que os problemas mais significativos a elas relacionados consistiam no aparecimento de cáries recidivas e resistência inadequada ao desgaste. Apesar da fórmula criada por Bowen significar um avanço significativo em direção à aplicabilidade das resinas acrílicas para fins restauradores, os esforços das décadas subsequentes produziram relativamente pouco com relação ao sucesso clínico esperado com o emprego de tais materiais (Leinfelder, 1997).

De acordo com Wilson (1989) a resistência ao impacto e a insolubilidade eram vantagens óbvias das resinas acrílicas restauradoras em relação aos cimentos de silicato mas, no entanto, o sucesso inicial desarticulou-se rapidamente quando da verificação de infiltração marginal, cáries recidivas e conseqüente perda da restauração, em função da contração de polimerização, baixo módulo de elasticidade e alto coeficiente 
de expansão térmica dos polímeros empregados nestes materiais comparados as mesmas propriedades físicas da dentina. O autor relata que a adesão dos materiais restauradores têm sido um aspecto considerado importante nas restaurações direta desde há muito tempo e já em 1961 realizou-se em Indiana, USA, um simpósio intitulado "Materiais Restauradores Adesivos".

Mesmo que em 1955 Buonocore, o inaugurador da era adesiva, supusesse indicações restritas de sua técnica de condicionamento do esmalte, um dos mais significativos avanços da Odontologia Restauradora, somente nos anos subsequentes verificou-se a amplitude das indicações de tal técnica para fins de restauração da integridade dental com resinas compostas. O tratamento bem sucedido com restaurações adesivas está diretamente relacionado com a adesão efetiva e a geometria do preparo nas restaurações tradicionais e, como técnica sensível, prescreve como indispensáveis o isolamento, a seleção dos materiais e a seqüência correta usada na técnica de adesão (Shortall \& Wilson, 1989).

Segundo Nakabayashi et al. (1982) o principal mecanismo de retenção dos atuais sistemas adesivos consiste na infiltração e polimerização subseqüente de monômeros resinosos através da camada superficial de dentina, previamente desmineralizada pelo condicionamento ácido compondo-se, desta forma, a camada híbrida. Neste trabalho de revisão da literatura sobre a adesão das resinas compostas, os autores aludem para que embora a adesão ao esmalte seja uma questão bem estabelecida a adesão à dentina ainda permanece um desafio, necessitando 
de muitos estudos, frente a características intrínsecas do tecido dentinário como a sua estrutura tubular, alto conteúdo orgânico e umidade (Reis et al., 2001).

Em 1995 Olivares et al. realizaram um trabalho in vitro para verficação da capacidade adesiva de cimentos de ionômero de vidro em relação à dentina, através do estudo da resistência adesiva de dois cimentos comerciais em relação à dentina radicular bovina em função da ciclagem térmica, tratamento da superfície dentinária e períodos de armazenamento. Os autores concluíram que a adesividade dentinária foi maior quando a dentina foi lavada apenas com água deixando-se permanecer a camada de magma dentinário, que o Ketac-Bond mostrou maior adesividade que o Vidrion R. e que houve uma influência pronunciada da ciclagem térmica como variável experimental assim como uma tendência a um aumento de adesividade dos corpos de prova armazenados por 1 semana quando comparados com os armazenados por $24 \mathrm{~h}$.

\subsection{CATALASE}

Em 1918 Tenard percebeu que células tanto animais como vegetais degradam o peróxido de hidrogênio formando oxigênio e em 1892 Jakobsen já mostrara que a reação era causada por uma enzima. Então, em 1901, Loew sugeriu o nome Catalase para esta enzima. Em 1936, Keilin \& Hartree mostraram que a Catalase também agiria como uma peroxidase e, dessa 
forma, esta poderia ser considerada como uma peroxidase especial que ao oxidar e reduzir o peróxido de hidrogênio produz, simultânea e respectivamente, oxigênio e água. Pertencente ao grupo das oxirredutases, a Catalase também é produzida pelo Aspergillus niger e pelo Micrococcus lysodeikticus. No caso da Catalase de fígado bovino, o $\mathrm{pH}$ de atividade enzimática varia entre 5 e 8 , com pH ótimo igual a 7 . A enzima produzida pelo $A$. niger tolera $65^{\circ} \mathrm{C}$ por alguns poucos minutos enquanto que a do $M$. lysodeikticus tem atuação ótima em pH 7.0 e $30^{\circ} \mathrm{C}$. Para fins analíticos, uma unidade Baker corresponde à quantidade de Catalase fúngica que promoverá a decomposição de $264 \mathrm{mg}$ de peróxido de hidrogênio sob as condições de reação definidas por Scott \& Hammer em 1960 (Uhlig, 1998).

A Catalase ou peroxidase, oxirredutase do peróxido de hidrogênio, é uma enzima encontrada nos peroxissomos do fígado, eritrócitos e em menor quantidade no rim de mamíferos. Uma das enzimas melhor estudadas, foi inicialmente cristalizada por Sumner \& Dounce a partir de fígado bovino em 1937, promove a destruição do peróxido de hidrogênio através de basicamente duas reações, uma catalítica e a outra peroxidática. O peróxido de hidrogênio é produzido no interior das células por um determinado número de reações enzimáticas como a catalizada pelas oxidases da flavina e pela superóxido dismutase que converte radicais livres superóxido em água oxigenada e água. Alternativamente, o peróxido de hidrogênio também se forma por via não enzimática através da auto oxidação de compostos como o tiol e o ascorbato. Uma vez que os excessos de peróxido de hidrogênio são altamente danosos, os organismos vivos desenvolveram 
substâncias como a Catalase, a glutadiona peroxidase e a superóxido dismutase para a eliminação dos mesmos. Com um peso molecular de aproximadamente 240.000 daltons e composta por quatro subunidades idênticas, cada qual contendo uma metade de ferroprotoporfirina, a Catalase de eritrócitos humanos pode ter suas subunidades dissociadas pela uréia, pela exposição a pH abaixo de 4 ou acima de 11 com conseqüente diminuição da atividade catalítica e ganho na atividade peroxidática. Após a produção de peróxido de hidrogênio e radicais livres através da reação inflamatória, macrófagos e eritrócitos circulantes atraídos para os sítios inflamatórios liberam citocinas que ao atingirem o fígado ativam a secreção de Catalase. Segundo esta hipótese a Catalase atuaria na eliminação de peróxido de hidrogênio reduzindo, consequentemente, a formação de radicais livres (Yasmineh \& Theologides, 1993).

Destarte o peróxido de hidrogênio seja um metabólito normal das células vivas, seu excesso necessita ser removido uma vez que este pode provocar a oxidação dos componentes celulares. Tanto a Catalase (EC 1.11.1.6) como a glutadiona peroxidase (EC 1.11.1.9) estão envolvidas na decomposição do peróxido de hidrogênio intracelular e estudos com eritrócitos, hepatócitos e cultura de fibroblastos fazem supor que enquanto a primeira é efetiva em concentrações relativamente altas de peróxido de hidrogênio, a segunda o é em baixas concentrações (Masuoka et al., 1996).

Precocemente reconhecida como um oligômero relativamente estável, a dissociação da Catalase resulta numa denaturação irreversível que normalmente ocorre em circunstâncias drásticas como abaixo de $\mathrm{pH} 3$, 
acima de $\mathrm{pH} 10$, na presença de detergentes ou mediante modificações químicas extensas da apoproteína (Schonbaum \& Chance, 1976).

Bowles \& Burns, em 1992, pesquisando a presença de Catalase na polpa dental analisaram amostras controle de homogeneizados teciduais de extratos pulpares e água destilada e amostras experimentais de homogeneizados e peróxido de hidrogênio a $30 \%$. Os pesquisadores mediram a absorbância dos preparados ao longo de um período de $3 \mathrm{~min}$, em intervalos de 15s, usando um espectrofotômetro ajustado a um comprimento de onda de $240 \mathrm{~nm}$. Verificaram que a Catalase presente no tecido pulpar apresenta uma atividade muito baixa frente a ação dos agentes oxidantes amplamente empregados no tratamento clareador de dentes dentes portadores de polpa viva. Salientaram, portanto, que os peróxidos devem ser utilizados com muito cuidado pois a penetração destes agentes é danosa.

Adibfar et al. (1992) avaliaram o efeito da imersão em água bidestilada, por 1, 5, 10, 20min. ou 7 dias, sobre blocos de esmalte bovino clareados através da imersão em $2 \mathrm{ml}$ de peróxido de hidrogênio a $35 \%$ por $1,3,5,30$ ou $60 \mathrm{~min}$. O grupo controle foi obtido através da imersão de 8 blocos de esmalte em $2 \mathrm{ml}$ de solução salina por 60min. e imersão em água bidestilada por 7 dias. Todas os espécimes foram condicionados com ácido fosfórico $37 \%$ por 60 s. Os autores identificaram e quantificaram o peróxido de hidrogênio liberado na água bidestilada através de espectrofotometria de absorção. Os resultados mostraram diferenças estatisticamente significantes quando comparados os grupos experimental e controle. Demonstraram 
também que sob imersão, a completa remoção do peróxido de hidrogênio do esmalte clareado ocorre rapidamente com restabelecimento dos níveis de adesividade anteriores ao tratamento clareador. Dessa forma os autores advogam que estudos posteriores devam ser conduzidos para avaliar o possível efeito da saliva, como um agente removedor, na eliminação do peróxido de hidrogênio absorvido e adsorvido e alojado nos espaços interprismáticos da superfície do esmalte.

Rotstein et al. (1993b) verificando o efeito protetor da Catalase contra a ação do peróxido de hidrogênio em mucosa de língua de rato observou que a aplicação da Catalase na mucosa antes da injeção de peróxido de hidrogênio preveniu completamente reação tecidual patológica. Este trabalho experimental foi realizado utilizando-se 37 ratos machos albinos cada um pesando aproximadamente $300 \mathrm{~g}$. Os animais foram mantidos em colônias padrões, alimentados de forma irrestrita, divididos em quatro grupos e os tratamentos foram aplicados na ponta de suas línguas. No grupo $1(n=18)$ os animais foram submetidos somente a peróxido de hidrogênio a $30 \%$. No grupo $2(n=13)$ as aplicações de peróxido de hidrogênio foram precedidas pela administração de Catalase C-40, $10 \mathrm{mg} / \mathrm{ml}, 10.000$ a 25.000 unidades por miligrama de proteína (Sigma Chemical Co., St. Louis, MO). Os dois grupos controle, cada um composto de 3 animais, foram tratados com solução fisiológica de cloreto de sódio (grupo 3) e Catalase sozinha (grupo 4). O tratamento consistiu de quatro aplicações repetitivas com intervalos de $15 \mathrm{~min}$. com alíquotas de $5 \mu \mathrm{l}$ da respectiva solução usando-se uma escova macia. 15min. após a primeira aplicação as pontas das línguas foram 
inteiramente lavadas com água. Alguns animais foram sacrificados imediatamente após a lavagem enquanto, outros 1 dia após e os remanescentes 7 dias mais tarde. Após o sacrifício as pontas das línguas foram dissecadas, fixadas, desidratadas, incluídas em parafina, seccionadas e coradas com hematoxilina-eosina. Então, as amostras foram submetidas à análise histomorfométrica empregando-se um sistema digital computadorizado. De uma forma geral observou-se uma reação global imediata e evidente marcada por edema da parte anterior da língua frente a aplicação do peróxido de hidrogênio a $30 \%$. Os danos teciduais causados pelo agente clareador foram completamente evitados com a aplicação da Catalase.

O pioneirismo dos pesquisadores reside na verificação in vivo dos efeitos adversos do peróxido de hidrogênio usando mucosa oral de rato. Assim observaram que a aplicação tópica da Catalase na mucosa oral pode efetivamente proteger estes tecidos e preveni-los dos danos causados pelo peróxido de hidrogênio. Dessa forma, os autores sugerem que esta pode ser usada como coadjuvante conveniente nos diferentes procedimentos de clareamento.

Em 1993, pesquisando sobre o efeito residual do peróxido de hidrogênio após o clareamento dental, Rotstein (1993c) investigou a eficácia do emprego da Catalase comparada com lavagens prolongadas com água na eliminação do peróxido residual. Para tanto utilizou 22 premolares humanos recém extraídos que foram tratados endodonticamente e obturados com gutta-percha e cimento $\mathrm{AH}-26$. O corte da obturação de 
gutta-percha foi estabelecido apicalmente a $3 \mathrm{~mm}$ da junção amelocementária e o cemento desta região removido. Então, as câmaras coronárias de 20 amostras foram pipetadas com $20 \mu$ l de peróxido de hidrogênio a $30 \%$ e 2 dentes, usados como controle, receberam a mesma quantidade de solução de soro fisiológico. Subseqüentemente, os dentes foram montados em um aparato para quantificação da penetração radicular de peróxido de hidrogênio pipetado no interior da câmara pulpar. Numa segunda etapa as câmaras coronárias foram preenchidas com Catalase de fígado bovino (C-40, $10 \mathrm{mg} / \mathrm{ml}, 10.000$ a 25.000 unidades/mg de proteína Sigma, St Louis-MO) procedendo-se a nova quantificação da penetração de peróxido de hidrogênio.

O autor verificou uma eliminação completa do peróxido de hidrogênio quando os dentes clareados foram tratados com a Catalase por um curto período e esses achados provam o fundamento lógico para sua aplicação clínica na cavidade oral, como preventivo dos efeitos adversos do peróxido de hidrogênio. Também observa que a ação da Catalase independe da temperatura e seu pH ótimo é razoavelmente amplo para seu uso clínico.

Em 1997 Liebenberg relatou um caso clínico de um paciente de 16 anos que apresentava um incisivo central superior esquerdo escurecido e que recebera tratamento endodôntico prévio após traumatismo. Para tanto idealizou o que chamou técnica Walking Bleach modificada de tal forma que o agente clareador era administrado pelo próprio paciente. Dessa forma, o paciente usava-se de uma moldeira de silicone especialmente confeccionada e que era preenchida várias vezes ao dia com o agente 
clareador peróxido de carbamida a $10 \%$ de tal forma que este penetrasse o interior da câmara do dente que permanecera aberto. Segundo o autor a restauração definitiva do elemento dental clareado prescreve necessariamente a neutralização do peróxido de hidrogênio residual e para tanto alude para considerações de outros autores que sugerem a prorrogação do momento de restauração para 7 dias após o clareamento uma vez que o oxigênio residual possa interferir com a polimerização da resina. Também sugere como alternativa a inclusão da Catalase num protocolo de clareamento assim como o emprego alternativo de adesivos à base de acetona.

Cabral et al. em 2001 relatam um caso clínico onde empregam de forma combinada as técnicas de clareamento dental intracoronário e extracoronário do dente 11 de um paciente do sexo masculino de 23 anos. 0 tratamento clareador extracoronário foi realizado 12 meses após a conclusão do retratamento endodôntico quando então se observava radiograficamente a cicatrização da lesão. Para tanto, empregaram peróxido de carbamida a $16 \%$ da Nite-White ${ }^{\circledR}$ durante a noite por uma semana através de moldeiras de vinil. Logo após o clareamento extracoronário, iniciou-se o clareamento intracoronário empregando-se uma pasta à base de perborato de sódio e peróxido de hidrogênio a $30 \%$, segundo os autores, uma variação da técnica proposta por Nutting \& Poe em 1963, ou seja, o emprego da pasta sem o uso de calor. Esta pasta foi colocada no interior da câmara pulpar até que se atingisse a cor desejada. Concluído o tratamento clareador intracoronário os autores empregaram, sob forma de solução irrigadora, a Catalase durante 
três sessões antecedentes à restauração definitiva do dente 11, para eliminar completamente o peróxido de hidrogênio residual.

Subseqüentemente, instituíram um regime de manutenção que consistia na confecção de novas moldeiras para aplicações noturnas do agente clareador a cada 5 meses e avaliação a cada 6 meses.

Os autores concluíram que as técnicas de clareamento intracoronário e extracoronário apresentam resultados bastante satisfatórios quando combinadas e representam a forma mais conservadora e econômica se comparadas ao tratamento restaurador protético. Discorrem ainda que os riscos do clareamento interno são limitados se as seguintes medidas são adotadas: (1) a colocação do tampão de hidróxido de cálcio ao nível ou acima do limite amelo-cementário para evitar que o produto clareador possa se difundir para a região cervical; (2) evitar a aplicação do calor, o que potencializaria a ação deletéria dos agentes clareadores e (3) o emprego da Catalase para neutralizar o peróxido de hidrogênio residual que possa estar presente nos canalículos dentinários. 


\section{PROPOSIÇÃO}

Este trabalho teve como propósito a análise in vitro da influência da Catalase, em diversas concentrações, na adesividade do material restaurador à dentina humana submetida ao clareamento com Peróxido de Hidrogênio a 30\% e Perborato de Sódio avaliando-se a resistência adesiva de corpos de prova em ensaios de tração em uma Máquina de Teste Universal. 


\section{MATERIAL E MÉTODOS}

\subsection{Material}

01) 40 dentes molares humanos hígidos extraídos fornecidos pelo Banco de Dentes da Disciplina de Endodontia da Faculdade de Odontologia da Universidade de São Paulo;

02) Solução de Soro Fisiológico (Solução de Cloreto de Sódio a 0,9\%, Fórmula \& Ação - Farmácia de Manipulação - São Paulo-SP);

03) Máquina de corte de precisão LABCUT 1010 (EXTEC) (Fig. 1);

04) Cera utilidade Wilson (Polidental Indústria e Comércio);

05) Matriz de plástico desmontável azul constituída de anel e fundo da marca Sampl-Kup (Buehler Ltda.) (Fig. 3):

06) Resina Poliester Uceflex UC 2120 (Redelease Produtos para Indústrias Ltda., São Paulo-SP) (Fig. 3);

07) Máquina Politriz Ecomet 3 (Buehler Ltd.) (Fig. 2);

08) Lixa d'água granulação \#320, \#400 e \#600 (Buehler Ltda) (Fig. 2);

09) Cronômetro digital;

10) Solução de Peróxido de Hidrogênio a 30\% (Fórmula \& Ação Farmácia de Manipulação - São Paulo-SP); 
11) Perborato de Sódio (Fórmula \& Ação - Farmácia de Manipulação - São Paulo-SP);

12) Água Destilada (Fármacia da Faculdade de Ciências Farmacêuticas da Universidade de São Paulo);

13) Solução de Hipoclorito de Sódio a $0,5 \%$ da Fármacia Fórmula e Ação (Fórmula \& Ação - Farmácia de Manipulação - São Paulo$\mathrm{SP})$;

14) Matriz de TEFLON, branca, tronco-cônica, desmontável (bipartida) especialmente confeccionada para este experimento pela Faculdade de Física da Universidade de São Paulo (Fig. 5);

15) Ácido Fosfórico a 35\% 3M Scotchbond ${ }^{\mathrm{MR}}$ Multi-Uso, 3ml, (3M do Brasil Ltda. - Produtos Dentários, Sumaré-SP);

16) Adesivo 3M Single Bond, 6ml, (3M do Brasil Ltda. - Produtos Dentários, Sumaré-SP);

17) 4 seringas de Compósito híbrido fotopolimerizável Tetric ${ }^{\circledR}$ Ceram - Advanced Composite Technology - 310/B3/30, 4g (Ivoclar Vivadent AG, FL-4949 Schaan / Liechtenstein);

18) Aparelho fotopolimerizador Heliomat (Ivoclar Vivadent, Inc., NY, EUA);

19) Solução de Catalase bovine liver (Catalase de fígado bovino) C9322, EC 1.11.1.6 (Sigma-Aldrich, St Louis, MO, EUA)

20) Máquina Instron mod. 4442 (Instron Corp., Canton, MA., EUA) (Fig. 7); 
21) Mesa para fixação do corpo de prova (Houston Biomaterial Research, Dental Branch, University of Texas, EUA)

22) Lupa de aumento de 20x (Intex - Ref. 23B);

23) 01 computador composto de um monitor SVGA de 14pol. AcerView 35cL (Acer) e de uma CPU com processador AMD K-6II de $550 \mathrm{mHz}$, Disco Rígido de 20Gyga-bytes e 64Mega-bytes de RAM;

24) Programa de computador para análise estatística GMC versão 8.1, editado em 01/03/2001, desenvolvido pelo Prof. Dr. Geraldo Maia Campos da Faculdade de Odontologia de Ribeirão Preto da Universidade de São Paulo-Ribeirão Preto;

25) 01 scanner ScanJet 3200C da Hewlett Packard.

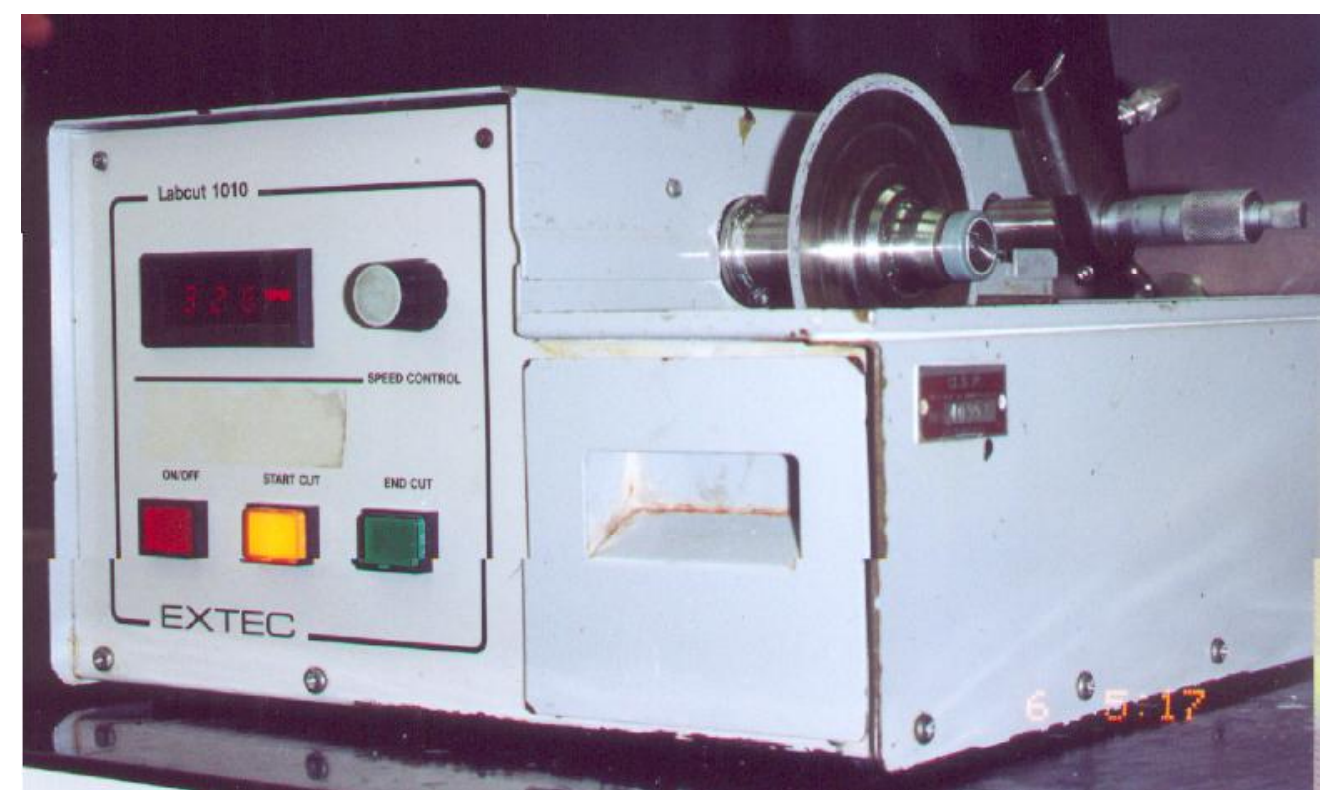

Fig. 1 - Máquina de corte de precisão LABCUT 1010 (EXTEC) para confecção dos espécimes através de seccionamentos transversais e longitudinais dos dentes. 


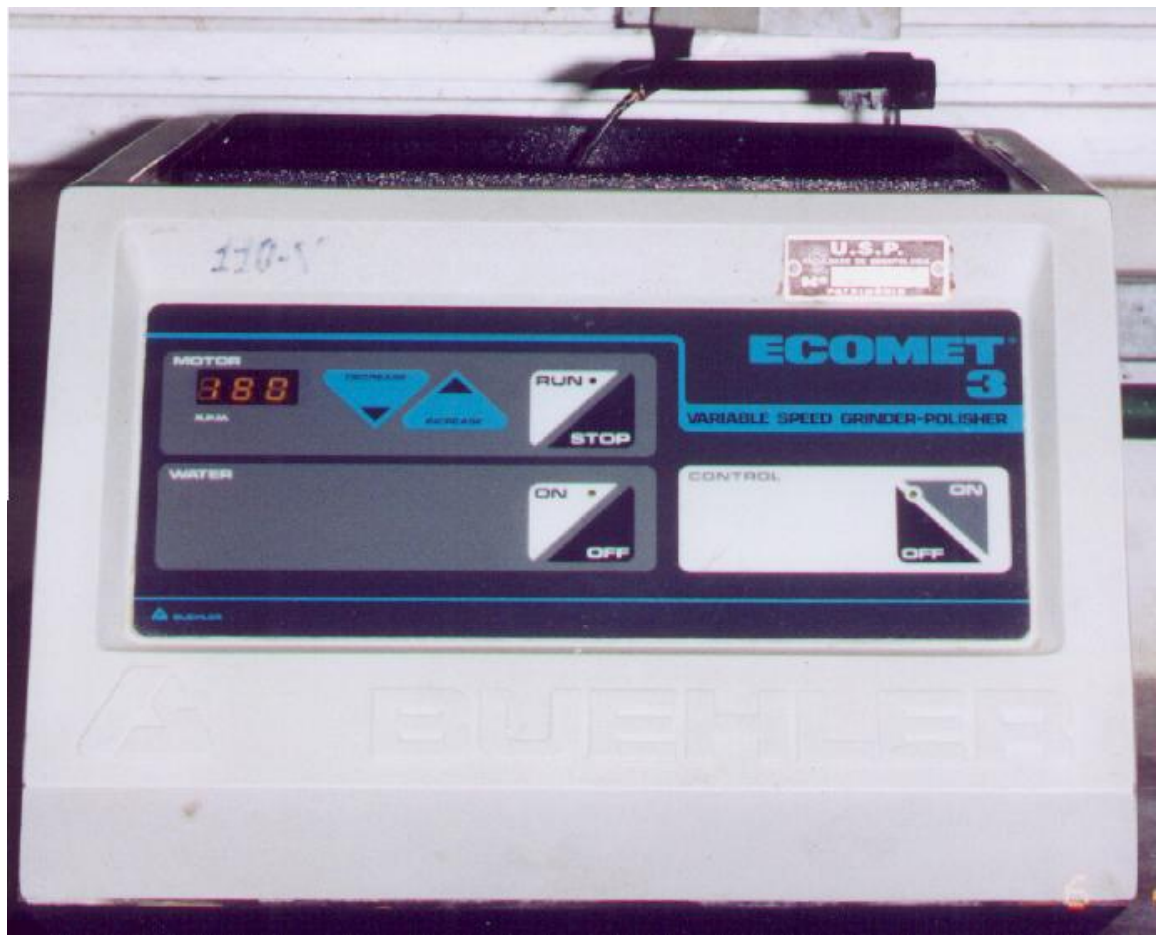

Fig. 2 - Máquina Politriz Ecomet 3 (Buehler Ltda.) para polimento dos espécimes incluídos em discos de resina acrílica transparente autopolimerizável.

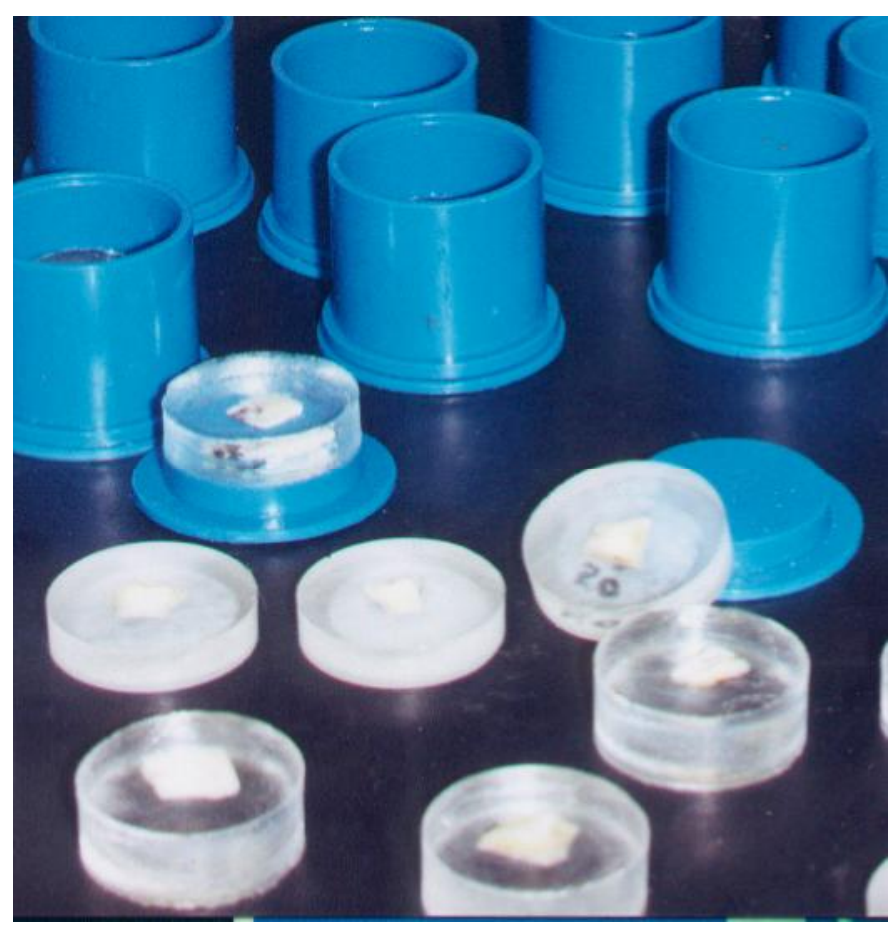

Fig. 3 - Espécimes incluídos em discos de resina acrílica transparente autopolimerizável confeccionados em matriz desmontável (anel e fundo). 


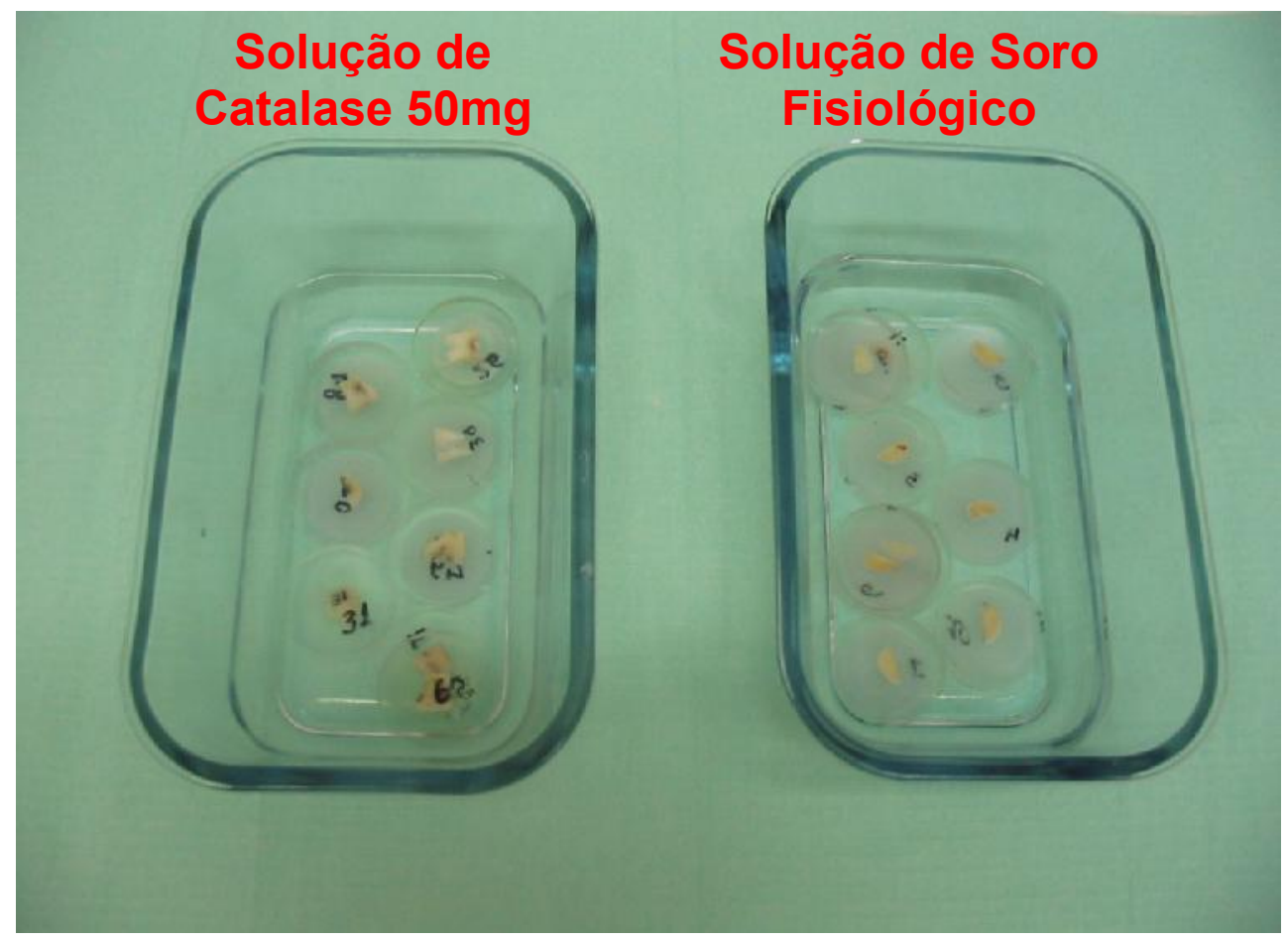

Fig. 4 - Espécimes incluídos em discos de resina acrílica transparente e imersos nas soluções experimentais

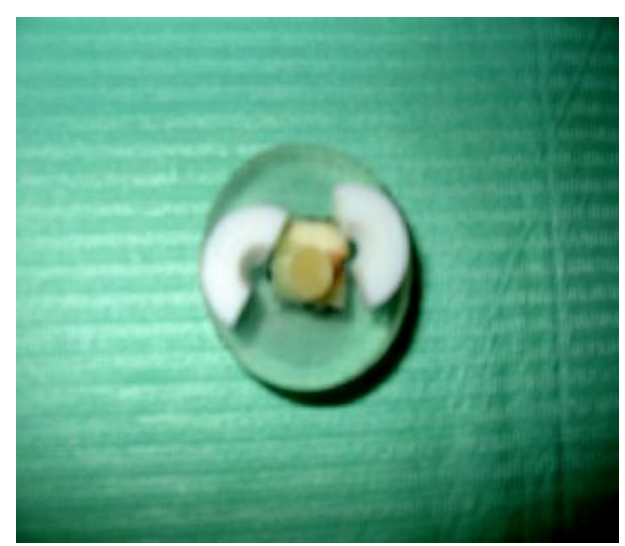

Fig. 5 - Matriz de TEFLON

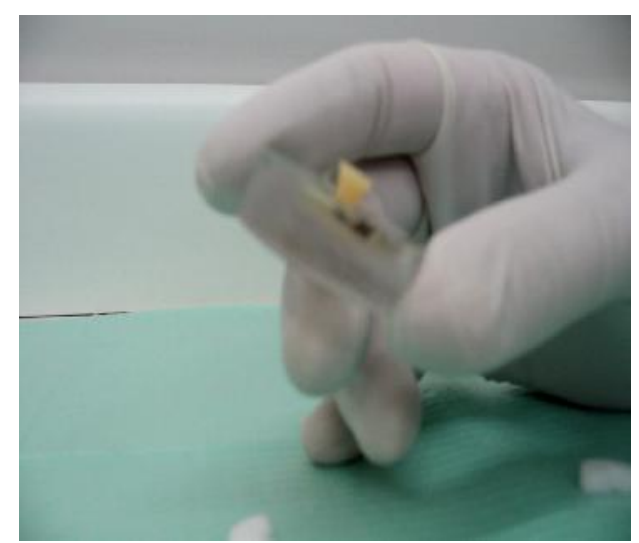

Fig. 6 - Corpo de prova 


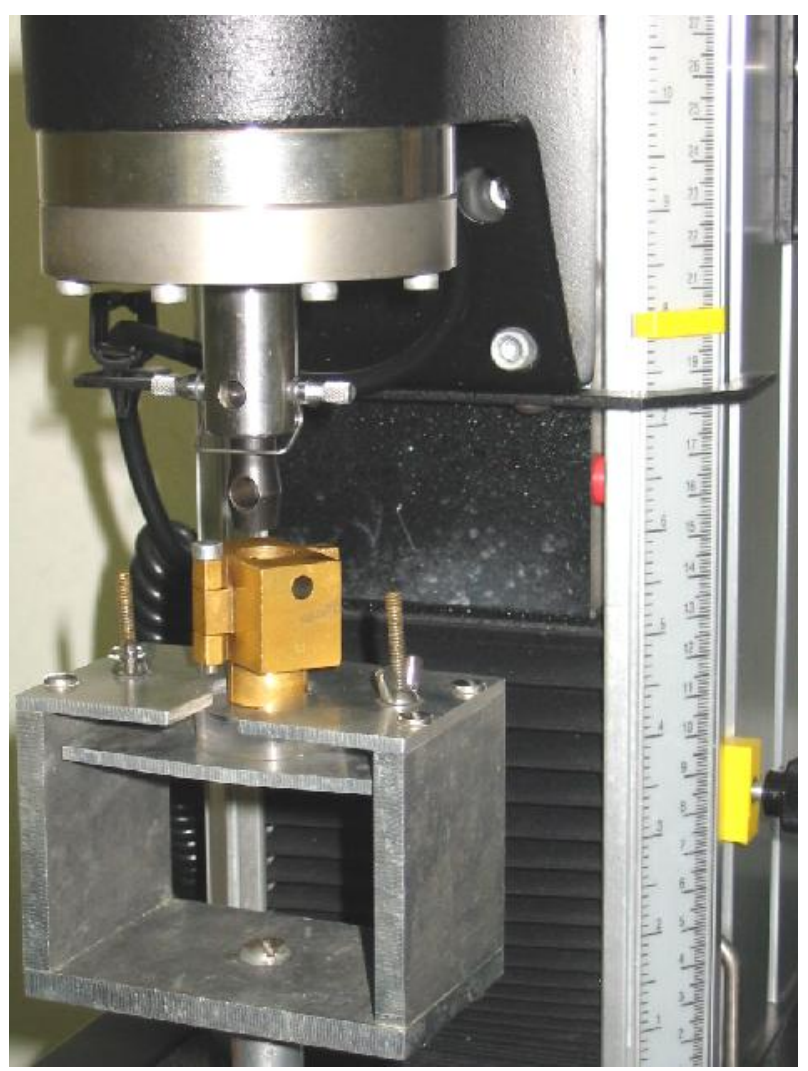

Fig. 7 - Máquina de Teste Universal Instron mod. 4442 (Instron Corp., Canton, MA., EUA) para ensaios de tração.

\subsection{Métodos}

Quarenta molares humanos hígidos extraídos por razões diversas foram aleatoriamente divididos em quatro grupos experimentais, cada qual composto de dez dentes, denominados Grupos I, II, III e IV.

Após o armazenamento em solução de soro fisiológico à temperatura ambiente por $48 \mathrm{~h}$, os espécimes foram preparados da seguinte forma:

1) as superfícies oclusais de todos os dentes foram aplainadas na máquina de corte de precisão LABCUT; 
2) as faces proximais de todos os dentes foram desgastadas com uma máquina Politriz até que se obtivessem áreas dentinárias suficientemente amplas, nos sentidos vestíbulo-lingual e corono-radicular, para receberem os corpos de prova;

3) em seguida as raízes foram seccionadas de tal forma a obterem-se áreas dentinárias de aproximadamente $5 \mathrm{~mm}$ de extensão no sentido coronoradicular;

4) finalmente, os dentes foram seccionados longitudinalmente no sentido vestibulo-lingual para a obtenção de um par de espécimes para cada dente, ou seja, uma metade mesial experimental e uma metade distal controle;

Após a identificação, cada um dos 80 espécimes foi incluído em resina acrílica autopolimerizável transparente em uma matriz desmontável de plástico azul, composta de um anel e um fundo removível sobre o qual os espécimes eram afixados com cera utilidade de tal forma que a face dentinária ficasse voltada para baixo em direção à face externa do anel que, após posicionado, era preenchido com a resina. Após $24 \mathrm{~h}$ o anel plástico era removido obtendo-se espécimes incluídos em um discos de resina e com suas faces dentinárias voltadas para o exterior.

A seguir os espécimes foram polidos utilizando-se uma máquina Politriz Ecomet 3 acoplada de lixas d'água de granulação \#320, \#400 e \#600, sucessivamente, refrigeradas com água corrente.

Então, os 80 espécimes obtidos do seccionamento dos 40 dentes, previamente distribuídos em 4 grupos experimentais, foram redistribuídos 
dividindo-se cada um dos grupos originais em dois subgrupos cada qual composto de 10 espécimes, da seguinte forma: Grupo IA, Grupo IB, Grupo IIA, Grupo IIB, Grupo IIIA, Grupo IIIB, Grupo IVA e Grupo IVB. Dessa forma, cada dente teve uma de suas metades nos grupos A e sua outra correspondente nos grupos B. Assim, para fins de padronização, para cada metade submetida ao agente clareador tivemos sua metade correspondente designada como controle e tratada com soro fisiológico.

Subseqüentemente, todos os 80 espécimes foram imersos em solução de Soro Fisiológico à temperatura ambiente por $48 \mathrm{~h}$ e, então, lavados em água corrente por 2 min. e secos com jatos de ar.

Em seguida, todos os espécimes foram condicionados com ácido ortofosfórico a $35 \%$ por 15 s, lavados abundantemente com água e secos com jatos de ar de uma seringa tríplice. Uma vez secos, cada disco de dentina recebeu uma pasta clareadora confeccionada de peróxido de hidrogênio a $30 \%$ e perborato de sódio que permaneceu em contato com as superfícies dentinárias por 30min. Após o clareamento os espécimes foram lavados com $10 \mathrm{ml}$ de solução de hipoclorito de sódio a $0,5 \%$ para inativação da pasta clareadora, lavados com água destilada e secos com jatos de ar de uma seringa tríplice.

Em seguida, os 40 espécimes dos grupos A foram imersos em diferentes soluções de Catalase (Fig. 4) enquanto os outros 40 dos grupos B (controle) foram imersos em solução de soro fisiológico (Tab. 1, Fig. 4). Cada um dos grupos de 10 espécimes permaneceu em $250 \mathrm{ml}$ de solução, 
tanto de Catalase (Grupos A) como de soro fisiológico (Grupos Controle), por 3min. (Tabela 1).

Tabela 1 - Grupos experimentais segundo as soluções testadas.

\begin{tabular}{|c|c|c|c|c|}
\hline \multirow{2}{*}{\multicolumn{2}{|c|}{$\begin{array}{c}\text { GRUPO } \\
\text { EXPERIMENTAL }\end{array}$}} & \multirow{2}{*}{$\begin{array}{c}\text { SOLUÇÃO } \\
\text { EXPERIMENTAL }\end{array}$} & \multirow{2}{*}{$\begin{array}{l}\text { VOLUME DE } \\
\text { IMERSÃO }\end{array}$} & \multirow{2}{*}{$\begin{array}{l}\text { TEMPO DE } \\
\text { IMERSÃO }\end{array}$} \\
\hline & & & & \\
\hline & A & Catalase $10 \mathrm{mg}$ & $250 \mathrm{ml}$ & $3 \mathrm{~min}$. \\
\hline \multirow[t]{2}{*}{ I } & B & Soro Fisiológico - Controle & $250 \mathrm{ml}$ & $3 \mathrm{~min}$. \\
\hline & A & Catalase $50 \mathrm{mg}$ & $250 \mathrm{ml}$ & $3 \mathrm{~min}$. \\
\hline \multirow[t]{2}{*}{ II } & B & Soro Fisiológico - Controle & $250 \mathrm{ml}$ & $3 \mathrm{~min}$. \\
\hline & A & Catalase $100 \mathrm{mg}$ & $250 \mathrm{ml}$ & $3 \mathrm{~min}$. \\
\hline \multirow[t]{2}{*}{ III } & B & Soro Fisiológico - Controle & $250 \mathrm{ml}$ & $3 \mathrm{~min}$. \\
\hline & A & Catalase $250 \mathrm{mg}$ & $250 \mathrm{ml}$ & $3 \mathrm{~min}$. \\
\hline IV & B & Soro Fisiológico - Controle & $250 \mathrm{ml}$ & $3 \mathrm{~min}$. \\
\hline
\end{tabular}

Após a imersão nas diversas soluções acima referidas, todos os espécimes foram imersos em $250 \mathrm{ml}$ de água destilada por $10 \mathrm{~min}$. , secos, condicionados com ácido ortofosfórico a 35\% na forma de gel, novamente lavados com água e secos para a aplicação do adesivo dentinário. Conforme a prescrição do fabricante o adesivo dentinário foi aplicado em duas camadas, sendo a primeira a título de primer e a segunda a título de bond, cada uma delas sendo polimerizada por um período de 40 s. 
A seguir, os discos de dentina receberam os corpos de prova que foram confeccionados através da inserção da resina composta Tetric $^{\circledR}$ Ceram no interior da matriz de TEFLON branca, tronco-cônica (Fig. 5). e bipartida, que permaneceu estabilizada por uma pequena mesa fixadora. A resina composta foi inserida em quatro incrementos, cada um fotopolimerizado por 40s, conforme prescrição do fabricante. As bases menores dos corpos de prova de $3 \mathrm{~mm}$ de diâmetro que permaneciam aderidas aos espécimes tinham uma área padrão no valor de $0,706 \mathrm{~cm}^{2}$ (Fig. 6).

Após a remoção da matriz de TEFLON, os espécimes acoplados dos corpos de prova foram levados à Máquina de Teste Universal Instron para a realização de testes de tração a uma velocidade de $0,5 \mathrm{~mm} / \mathrm{min}$. Os registros em Newton das quantidades de carga necessárias para o deslocamento dos corpos de prova foram devidamente anotados.

A metodologia de pesquisa empregada neste experimento é similar à empregada por Barakat \& Powers (1986); Berry \& Powers (1994); Fredl et al. (1995); Xie et al. (1996) e por Mathias (1998). 


\section{RESULTADOS}

Os dados amostrais originais foram obtidos de ensaios de tração em uma Máquina de Teste Universal Instron na forma de valores de carga referentes às forças de tração necessárias para a fratura dos corpos de prova em cada um dos oitenta espécimes dos diferentes grupos experimentais e controle. Os valores obtidos foram devidamente registrados e encontram-se relacionados na Tabela An.A8 e ilustrados nos Gráficos An.A4 e An.A5.

As Médias Aritméticas dos valores de carga necessários para a fratura dos corpos de prova, tanto para os grupos experimentais como para os seus respectivos grupos controle, encontram-se relacionadas na Tabela An.A9 e ilustradas no Gráfico An.A6.

Considerando-se a variável analisada neste experimento, a adesividade do material restaurador à dentina clareada e não clareada, segundo os fatores de variação múltiplos e independentes na forma das diferentes concentrações das soluções de Catalase analisadas, assim como as tensões mecânicas desenvolvidas ao nível da interface superfície dentinária-corpo de prova em função da força de tração aplicada em cada um dos oitenta espécimes dos diferentes grupos experimentais e de seus 
respectivos grupos controle, os valores originais de carga de deslocamentofratura em Newton $(\mathrm{N})$ foram correlacionados aos valores das áreas dos corpos de prova aderidas aos espécimes de tal forma que os valores de carga foram convertidos em valores de tensão mecânica na forma de Resistência Adesiva em MegaPascal (MPa), conforme Silva (1998), aplicando-se a fórmula abaixo descrita:

$$
\begin{aligned}
& \text { RA }=\frac{\mathrm{F}}{10 \times \mathrm{S}} \times 0,09807 \\
& \text { onde: } \\
& \mathrm{RA} \quad=\text { Resistência Adesiva } \\
& \mathrm{F} \quad=\text { Força em Newton } \\
& \mathrm{S} \quad=\text { área de adesão do corpo de prova }\left(\mathrm{cm}^{2}\right) \\
& 0,09807=\text { fator de correção de } \mathrm{kp} / \mathrm{cm}^{2} \mathrm{em} \mathrm{MPa}
\end{aligned}
$$

Uma vez que a área do corpo de prova em contato com o espécime era padrão, os valores de Resistência Adesiva puderam ser calculados multiplicando-se cada valor de carga, força de deslocamento em Newton (N), por 0,1387 , ou seja:

$$
R A=F \times 0,1387
$$

A tabela e os gráficos que se seguem apresentam os valores de Resistência Adesiva à fratura para os quatro diferentes grupos experimentais bem como para os seus respectivos grupos controle: 
Tabela 2 - Valores das Resistências Adesivas à fratura dos corpos de prova dos grupos experimentais e de seus respectivos grupos controle.

\begin{tabular}{ccccccccc}
\hline Esp. & $\begin{array}{c}\text { 1A } \\
\text { Catalase } \\
\text { 10mg }\end{array}$ & $\begin{array}{c}\text { 1B } \\
\text { Soro } \\
\text { Fisiol. }\end{array}$ & $\begin{array}{c}\text { 2A } \\
\text { Catalase } \\
\text { 50mg }\end{array}$ & $\begin{array}{c}\text { 2B } \\
\text { Soro } \\
\text { Fisiol. }\end{array}$ & $\begin{array}{c}\text { 3A } \\
\text { Catalase } \\
\text { 100mg }\end{array}$ & $\begin{array}{c}\text { 3B } \\
\text { Soro } \\
\text { Fisiol. }\end{array}$ & $\begin{array}{c}\text { 4A } \\
\text { Catalase } \\
\text { 250mg }\end{array}$ & $\begin{array}{c}\text { 4B } \\
\text { Soro } \\
\text { Fisiol. }\end{array}$ \\
\hline 01 & 1,94 & 2,49 & 3,76 & 3,68 & 2,99 & 2,04 & 4,93 & 3,93 \\
02 & 5,32 & 2,13 & 4,33 & 6,13 & 1,75 & 2,15 & 8,21 & 4,99 \\
03 & 1,35 & 5,54 & 3,96 & 3,72 & 3,20 & 1,49 & 6,38 & 1,44 \\
04 & 1,10 & 1,06 & 1,16 & 3,45 & 2,33 & 2,39 & 8,65 & 6,66 \\
05 & 4,02 & 3,86 & 7,36 & 8,81 & 4,55 & 2,84 & 5,37 & 6,32 \\
06 & 3,33 & 4,89 & 6,88 & 2,05 & 2,86 & 5,25 & 4,70 & 0,95 \\
07 & 1,47 & 2,08 & 2,34 & 4,77 & 2,24 & 0,92 & 5,16 & 1,82 \\
08 & 1,25 & 0,84 & 2,92 & 6,10 & 2,79 & 5,91 & 3,51 & 3,70 \\
09 & 5,35 & 1,16 & 1,48 & 9,14 & 4,53 & 4,96 & 2,90 & 2,08 \\
10 & 7,97 & 6,14 & 4,02 & 4,20 & 4,89 & 7,45 & 5,61 & 1,50 \\
\hline
\end{tabular}

unidade de medida: MegaPascal

\section{Grupos Experimentais x Resistência Adesiva}

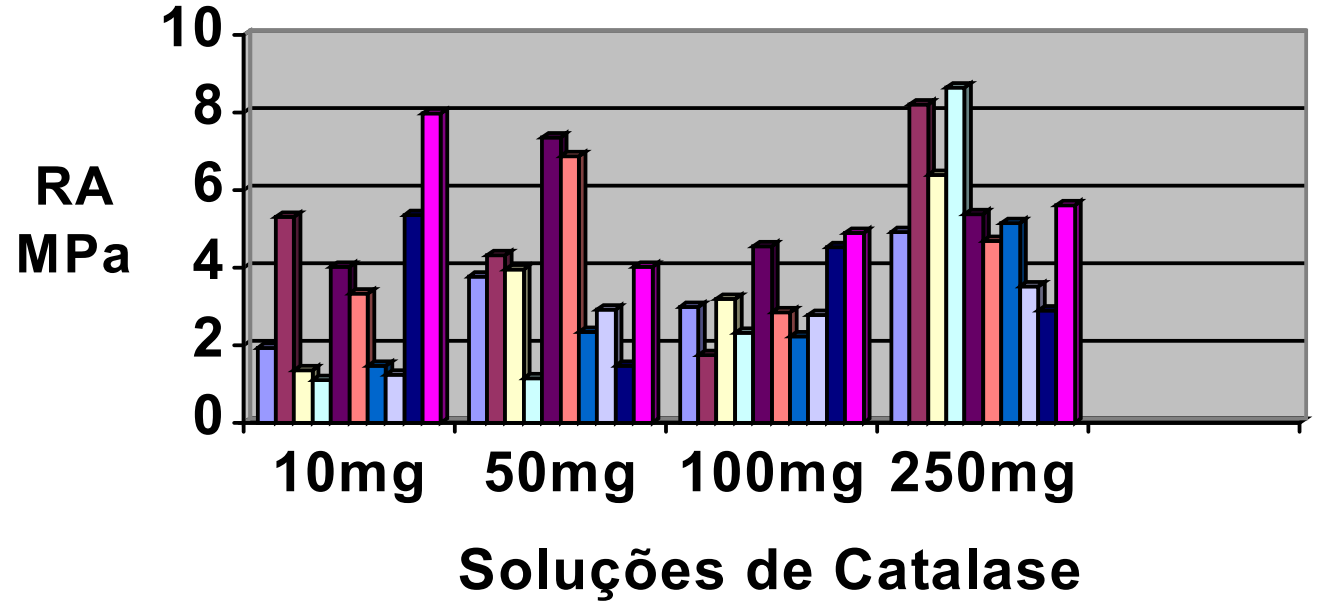

\section{$1 \square 2 \square 3 \square 4 \square 5 \square 6 \square 7 \square 8 \square 9 \square 10$}

Grafico 1 - Valores individuais das Resistências Adesivas dos grupos experimentais Catalase. 


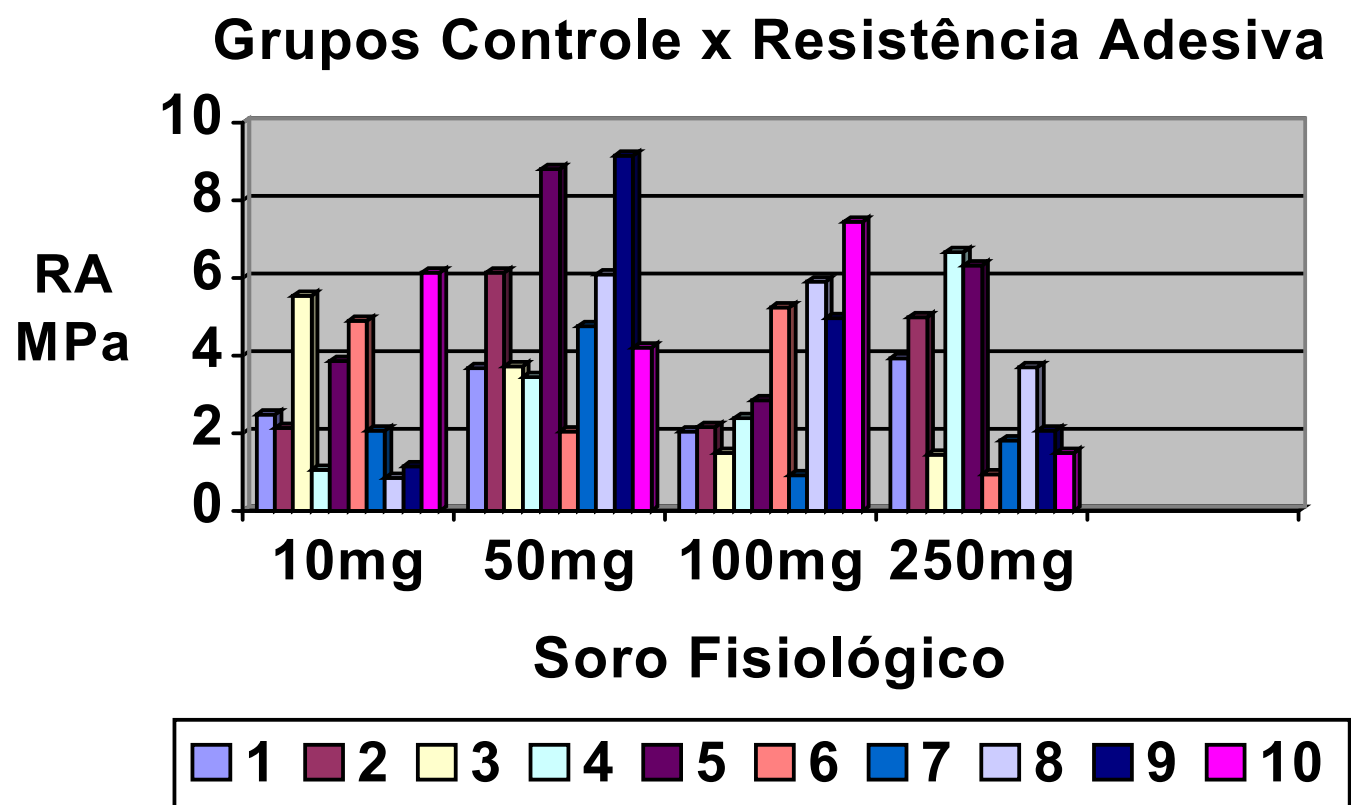

Grafico 2 - Valores das Resistência Adesivas dos grupos controle.

As Médias Aritméticas dos valores das Resistências Adesivas à fratura dos corpos de prova, tanto para os grupos experimentais como para os seus respectivos grupos controle, encontram-se relacionadas na Tabela 3 e ilustradas no Gráfico 3, abaixo dispostos:

Tabela 3 - Médias Aritméticas dos valores das Resistências Adesivas à fratura dos corpos de prova nos grupos experimentais e em seus respectivos grupos controle.

\begin{tabular}{c|cccc}
\hline & \multicolumn{5}{|c}{ Catalase } \\
Médias Aritméticas & $1 \mathrm{~A}$ & $2 \mathrm{~A}$ & $3 \mathrm{~A}$ & $4 \mathrm{~A}$ \\
dos valores de & 2,9 & 3,3 & 2,6 & 5,6 \\
Resistência & \multicolumn{4}{c}{ Controle } \\
Adesiva & 1B & $2 \mathrm{~B}$ & $3 \mathrm{~B}$ & $4 \mathrm{~B}$ \\
& 2,6 & 4,8 & 3,0 & 2,7 \\
\hline
\end{tabular}




\section{MEDIAS ARITMETICAS DE RESISTENCIA ADESIVA Grupos Experimentais x Grupos Controle}

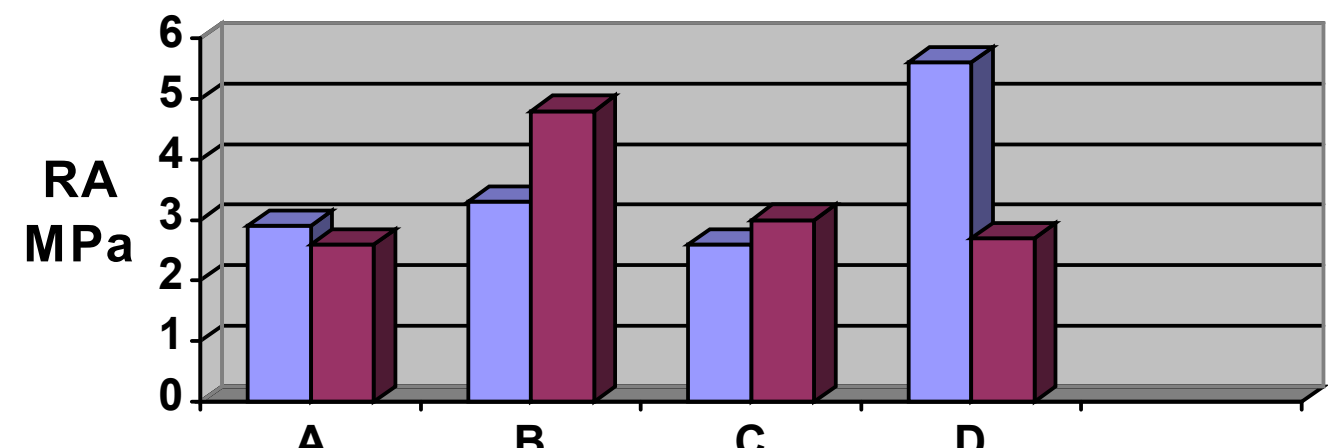

A

B

C

D

Catalase x Soro Fisiológico

$\square$ Catalase $\square$ Soro Fisiológico

Gráfico 3 - Médias Aritméticas dos valores das Resistências Adesivas dos corpos de prova dos grupos experimentais e de seus respectivos grupos controle.

A análise estatística dos dados experimentais foi realizada submetendo-se, preliminarmente, os valores de Resistência Adesiva aos Testes de Normalidade para a verificação das características da distribuição de freqüências da amostra em relação à curva normal. Os Parâmetros Amostrais e a Distribuição de Freqüências encontram-se nas Tabelas An.A10 e An.A11, respectivamente, seguindo-se abaixo a Tabela 4 com o Teste de Aderência à Curva Normal demonstrando que a amostra analisada, constituída dos 40 espécimes dos quatro grupos experimentais tratados com Catalase, não é normal. 
Tabela 4 - Teste de Aderência à Curva Normal para as amostras dos espécimes tratados com Catalase.

\begin{tabular}{|c|c|c|c|c|c|c|c|c|}
\hline \multirow{3}{*}{$\begin{array}{l}\text { Freqüências } \\
\text { por } \\
\text { intervalos de } \\
\text { classe }\end{array}$} & $\begin{array}{l}\text { Intervalos de } \\
\text { classe }\end{array}$ & M-3s & M-2s & M-1s & Med. & $M+1 s$ & $M+2 s$ & $M+3 s$ \\
\hline & Curva normal & 0.44 & 5.40 & 24.20 & 39.89 & 24.20 & 5.40 & 0.44 \\
\hline & $\begin{array}{l}\text { Curva } \\
\text { experimental } \\
\text { Graus de }\end{array}$ & 0.00 & 0.00 & 40.00 & 32.50 & 17.50 & 10.00 & 0.00 \\
\hline \multirow{3}{*}{$\begin{array}{c}\text { Cálculo do } \\
\text { Qui } \\
\text { quadrado }\end{array}$} & liberdade & \multicolumn{7}{|l|}{4} \\
\hline & $\begin{array}{c}\text { Valor do Qui } \\
\text { quadrado }\end{array}$ & \multicolumn{7}{|l|}{ 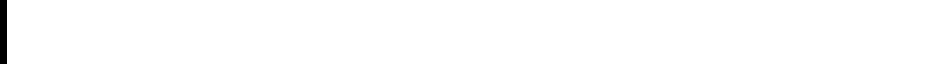 } \\
\hline & $\begin{array}{c}\text { Probabilidade } \\
\text { de Ho }\end{array}$ & \multicolumn{7}{|c|}{$0.0100 \%$} \\
\hline Interpretação & $\mathrm{AO}$ & tribuiçã & $0 \mathrm{~m}$ & $501+$ & & 6́n & & \\
\hline
\end{tabular}

Tendo o Teste de Aderência demonstrado que a distribuição de freqüências da amostra não é normal, os dados amostrais foram submetidos ao Teste Estatístico Não Paramétrico de Kruskal-Wallis (Tab. 5) para comparações múltiplas de fatores independentes, ou seja, a comparação dos diversos valores de Resistência Adesiva segundo as diferentes concentrações da solução de Catalase utilizadas. Rejeitando a Hipótese de Nulidade, o Teste de Kruskal-Wallis demonstra haver diferenças estatisticamente significantes entre os grupos amostrais ao nível de 5\%, uma vez que o valor do Qui-quadrado calculado para 3 graus de liberdade 8,25 é superior ao valor 7,82 fornecido em tabela para $\alpha=5 \%$. 
Tabela 5 - Teste de Kruskal-Wallis para os grupos experimentais Catalase.

\begin{tabular}{c|c}
\hline Valor $(\mathrm{H})$ de Kruskal-Wallis calculado & 8.2504 \\
Valor do $\mathrm{X}^{2}$ para 3 graus de liberdade & 8.25 \\
Probabilidade de Ho para esse valor & $4.11 \%$ \\
\hline O valor de H aparece repetido como X $\mathrm{X}^{2}$ porque a sua significância foi \\
avaliada pela tabela do qui-quadrado \\
\hline
\end{tabular}

Dessa forma, procedeu-se à comparação das médias dos postos das amostras, conforme a Tabela 6.

Tabela 6 - Comparação das Médias dos grupos experimentais Catalase

\begin{tabular}{|c|c|c|c|c|c|c|c|}
\hline \multicolumn{8}{|c|}{ Comparação entre Médias dos postos das amostras } \\
\hline \multirow{2}{*}{\multicolumn{3}{|c|}{$\begin{array}{c}\text { Amostras comparadas } \\
\text { (comparações duas a } \\
\text { duas) }\end{array}$}} & \multirow{3}{*}{$\begin{array}{c}\begin{array}{c}\text { Diferenças } \\
\text { entre } \\
\text { médias }\end{array} \\
2.7500\end{array}$} & \multicolumn{2}{|c|}{ Valores críticos } & \multirow{2}{*}{$\begin{array}{c}(\mathrm{a}) \\
0.001\end{array}$} & \multirow[t]{2}{*}{ Significância } \\
\hline & & & & 0,05 & 0,01 & & \\
\hline CAT10A & $\bar{x}$ & CAT50A & & 9.6692 & 12.9710 & 17.0999 & $n s$ \\
\hline CAT10A & $x$ & CAT100A & 0.6000 & 9.6692 & 12.9710 & 17.0999 & $n s$ \\
\hline CAT10A & $x$ & CAT250A & 12.4500 & 9.6692 & 12.9710 & 17.0999 & $5 \%$ \\
\hline CAT50A & $x$ & CAT100A & 3.3500 & 9.6692 & 12.9710 & 17.0999 & $n s$ \\
\hline CAT50A & $\mathrm{x}$ & CAT250A & 9.7000 & 9.6692 & 12.9710 & 17.0999 & $5 \%$ \\
\hline CAT100A & $x$ & CAT250A & 13.0500 & 9.6692 & 12.9710 & 17.0999 & $1 \%$ \\
\hline
\end{tabular}

A comparação das médias (Tab. 6) dos valores de Resistência Adesiva dos corpos de prova dos espécimes dos grupos experimentais em que os espécimes foram imersos em Catalase não demonstra diferenças estatisticamente significantes entre os grupos experimentais G I A (10mg) e G II A (50mg), G I A (10mg) e G III A (100mg) assim como entre os grupos G 
II A (50mg) e G III A (100mg), tanto para $\alpha=1 \%$ como para $\alpha=5 \%$. Por outro lado, demonstra diferenças estatisticamente significantes para $\alpha=1 \%$ somente entre os grupos experimentais G III A (100mg) e G IV A (250mg), uma vez que a diferença entre as médias dos postos das referidas amostras é superior ao valor crítico no nível de significância considerado. Da mesma forma, verifica-se diferenças estatisticamente significantes para $\alpha=5 \%$ ao se compararem os grupos experimentais G I A (10mg) e G IV (250mg), assim como os grupos experimentais G II A (50mg) e G IV A (250mg), uma vez que as diferenças entre as médias dos postos das referidas amostras são superiores aos valores críticos no nível de significância considerado.

A comparação de cada um dos grupos experimentais Catalase com o seu respectivo grupo controle foi realizada submetendo-se os valores de Resistência Adesiva ao Teste Estatístico U de Mann-Whitney destinado à comparação de pares de amostras independentes. Os resultados encontrados estão dispostos na tabela abaixo:

Tabela 7 - Teste $U$ de Mann-Whitney para comparações dos grupos experimentais com seus respectivos controles

\begin{tabular}{|c|c|c|c|c|c|c|c|c|}
\hline $\begin{array}{c}\text { Grupo } \\
\text { Experimental } \\
\mathbf{X} \\
\text { Controle }\end{array}$ & $\begin{array}{c}1 \mathrm{~A} \\
\text { Catalase } \\
10 \mathrm{mg}\end{array}$ & $\begin{array}{c}\text { 1B } \\
\text { Soro } \\
\text { Ffsiol. }\end{array}$ & $\begin{array}{c}2 \mathrm{~A} \\
\text { Catalase } \\
50 \mathrm{mg}\end{array}$ & $\begin{array}{c}\text { 2B } \\
\text { Soro } \\
\text { Ffsiol. }\end{array}$ & $\begin{array}{c}3 \mathrm{~A} \\
\text { Catalase } \\
100 \mathrm{mg}\end{array}$ & $\begin{array}{c}\text { 3B } \\
\text { Soro } \\
\text { Ffsiol. }\end{array}$ & $\begin{array}{c}4 \mathrm{~A} \\
\text { Catalase } \\
250 \mathrm{mg}\end{array}$ & $\begin{array}{c}\text { 4B } \\
\text { Soro } \\
\text { Ffsiol. }\end{array}$ \\
\hline Valores de U & 51 & 49 & 31 & 69 & 47 & 53 & 78.5 & 21.5 \\
\hline $\begin{array}{c}\text { Valor calculado } \\
\text { de } z \\
\text { Probabilidade } \\
\text { de igualdade } \\
\left(\mathrm{H}_{0}\right) \\
\text { Interpretação }\end{array}$ & $\begin{array}{r}46.95 \\
\text { não sign } \\
\text { amostras } \\
(\alpha>0\end{array}$ & $\begin{array}{l}\% \\
\text { icante } \\
\text { iguais } \\
05 \text { ) }\end{array}$ & $\begin{array}{r}7.55 \\
\text { não signi } \\
\text { amostras } \\
(\alpha>0\end{array}$ & $\begin{array}{l}\% \\
\text { ficante } \\
\text { iguais } \\
05 \text { ) }\end{array}$ & $\begin{array}{l}41.0 \\
\text { não sign } \\
\text { amostra } \\
\quad(\alpha>0\end{array}$ & $\begin{array}{l}\% \\
\text { ficante } \\
\text { iguais } \\
05)\end{array}$ & $\begin{array}{r}1.56 \\
\text { signific } \\
\text { ao nivel } \\
(\alpha=0\end{array}$ & $\begin{array}{l}\% \\
\text { ante } \\
\text { de } 5 \% \\
05)\end{array}$ \\
\hline
\end{tabular}


Os resultados dos Testes de Normalidade (Parâmetros Amostrais, Distribuição de Freqüências e Teste de Aderência) dos valores de Resistência Adesiva dos espécimes que foram imersos em Solução de Soro Fisiológico encontram-se nas Tabelas An.A12, An.A13 e An.14 e os resultados da análise estatística, Teste de Kruskal-Wallis e Comparação das Médias, encontram-se respectivamente nas Tabelas An.A15 e An.A16. Rejeitando a Hipótese de Nulidade, o Teste de Kruskal-Wallis demonstra diferenças estatisticamente significantes entre os grupos controle, ao nível de $5 \%$, uma vez que o valor de Qui-quadrado calculado para 3 graus de liberdade 9,89 é superior ao valor 7,82 fornecido em tabela para $\alpha=5 \%$. A comparação das médias dos postos das amostras do grupos controle demonstra diferenças estatisticamente significantes entre os grupos G I B (10mg) e G II B (50mg) e entre os grupos G II B (50mg) e G IV B (250mg) para $\alpha=5 \%$ 


\section{DISCUSSÃO}

O clareamento de dentes cromaticamente alterados e tratados endodonticamente pode estar indicado antes que uma restauração de resina composta ou uma restauração indireta sejam confeccionadas para que se obtenha uma tonalidade final mais agradável para o caso em questão.

Desde a introdução da técnica de condicionamento ácido do esmalte dentário por Buonocore em 1955 com vistas a uma melhor retenção do material restaurador ao dente, as atuais técnicas restauradoras demandam também o condicionamento da dentina, o total-etch, A especificação ASTM D 907 (American Society for Testing and Materials) define adesão como "o estado em que duas superfícies são mantidas unidas, por forças interfaciais, as quais podem consistir em forças covalentes, forças de interpenetração mecânica, ou ambas." (sic) (Perdigão \& Ritter, 2001).

Apesar do mecanismo de adesão dos materiais adesivos à dentina ainda não ser bem compreendido, tem-se sugerido o imbricamento micromecâncio destes com a malha de fibras colágenas expostas pelo condicionamento ácido semelhantemente ao mecanismo de adesão ao esmalte. No entanto, a adesão à dentina ainda consiste desafio por ser esta um substrato heterogêneo, de alto conteúdo orgânico intrinsicamente úmido, 
além de que variáveis como o diâmetro e o comprimento dos túbulos dentinários, a viscosidade do fluído tubular, o gradiente de pressão, a abertura dos túbulos assim como a espessura de dentina remanescente após o preparo cavitário ainda não foram adequadamente consideradas (Perdigão \& Ritter, 2001 e Reis et al., 2001-2002).

Os menores valores de resistência adesiva encontrados nas regiões dentinárias mais próximas da polpa tem sido atribuídos à maior quantidade de canalículos dentinários e a sua disposição irradiada assim como à menor quantidade de dentina intertubular (Mathias, 1998; Baratieri, 2001). Dessa forma, a espessura de $1,5 \mathrm{~mm}$ (regiões superficiais das faces proximais de molares humanos adultos) dos espécimes empregados neste experimento não constituiu um fator determinante de diminuição das forças de adesão.

A última geração de adesivos dentinários, monômeros hidrofílicos e hidrófobos dissolvidos em acetona ou etanol, preconizados para serem usados em dentina úmida, tem sido proposta para a diminuição do tempo operatório de tal forma que aplicação de cada uma das duas camadas, conforme orientação do fabricante, substitui o primer e o bond dos sistemas adesivos de dois frascos (Perdigão \& Ritter, 2001).

Os valores de resistência adesiva à fratura de corpos de prova de resina composta em esmalte não clareado são maiores ou iguais a $20 \mathrm{MPa}$ enquanto que em relação à dentina estão entre 3 e 30MPa (Perdigão \& Ritter, 2001).

Desde o relato de casos clínicos de reabsorção radicular cervical externa pós tratamento clareador, por Harrington \& Natkin (1979), vários 
pesquisadores têm relatado que os agentes clareadores à base de peróxido de hidrogênio e peróxido de carbamida afetam de forma adversa a adesividade dos materiais restauradores tanto ao esmalte como à dentina de dentes humanos clareados, vitais ou endodonticamente tratados (Titley et al., 1993; Garcia-Godóy, 1993; Fortuna, 1996; Swift Jr., 1997; van der Vyver, 1997; Perdigão et al., 1998 e Sung et al., 1999).

A partir de experimentos in vitro com dentes humanos ou bovinos, vários autores atribuem a redução das forças de adesão á dentina clareada, segundo valores menores de resistência adesiva, tanto às alterações microestruturais decorrentes do tratamento clareador como ao peróxido de hidrogênio remanescente no interior dos túbulos da massa dentinária (Titley et al., 1988a, 1988b, 1988c; Titley et al, 1989; Torneck et. al, 1990, 1991; Titley et al., 1991; Titley et al., 1992; Rotstein et al., 1992a; Titley et al., 1993; Fortuna, 1996; van der Vyver, 1997; Silva e Souza Jr. \& Oliveira, 1997; Mathias, 1998; Spyrides et al., 2000 e Perdigão et al., 1998).

No que diz respeito às forças de adesão diminuídas, entre a dentina clareada e os materiais restauradores, uma das recomendações mais comuns na literatura consiste em protelar-se os procedimentos adesivos para $24 \mathrm{~h}$ até 1 semana após o tratamento clareador tal forma a permitir-se a desintegração do oxigênio residual com conseqüente melhora dos níveis de adesividade (Torneck et al., 1991).

Rotstein (1993c) sugeriu o emprego da enzima Catalase C-40, de 10.000 a 25.000 unidades por miligrama de proteína, como um auxiliar efetivo no tratamento clareador para prevenção de seus efeitos adversos. 0 
pesquisador baseou seu trabalho em um estudo experimental in vivo no qual a aplicação tópica de Catalase em mucosa oral de rato foi efetiva e preveniu a ação deletéria do peróxido de hidrogênio nestes tecidos.

A partir do trabalho de Rotstein (1993), Cabral et al. (2000) apresentaram um caso clínico no qual os autores utilizaram a mesma enzima (Catalase C-40) em forma de solução irrigadora por 3min. após terapia clareadora de um dente 11, antes da restauração com resina composta, visando uma melhor adesividade da mesma propiciada pela eliminação do peróxido de hidrogênio residual.

Um outro autor (Lienberberg, 1997) sugeriu que a Catalase fosse incluída num protocolo da terapia clareadora visando minimizar os efeitos deletérios causados pela presença dos possíveis radicais oxidantes decorrentes da degradação do peróxido de hidrogênio, que interfeririam com a polimerização das resinas compostas junto à estrutura dentinária.

Dessa forma, com base nas sugestões de Rotstein (1993), Lienberberg (1997) e Cabral (2000) buscamos através desse experimento in vitro avaliar o desempenho de diferentes concentrações de Catalse visando futuras aplicações de ordem clínica na restauração das propriedades adesivas de dentina humana clareada.

Os espécimes foram condicionados com ácido ortofosfórico 35\% por 15s com vistas à remoção do magma dentinário para aumento da permeabilidade dentinária e, consequentemente, melhor difusão do agente clareador através dos túbulos dentinários. Valores maiores de resistência adesiva tem sido obtidos com soluções de ácido na concentração de 35\%, 
uma vez que os precipitados produzidos podem ser facilmente removidos através da lavagem com água. Por outro lado, os estudos demonstram que um período de condicionamento de $15 \mathrm{~s}$ é suficientemente amplo para produzir superfícies com a mesma rugosidade produzida com 60s (Baratieri, 2001).

Cada um dos oitenta espécimes foi submetido ao tratamento clareador empregando-se uma pasta de peróxido de hidrogênio a 30\% e perborato de sódio preconizada por Prinz (1924), Nutting \& Poe (1963), Canepa et al., (1993), Pécora et al. (1996d), Silveira \& Berger (1998), Baratieri (2001), na técnica mediata de clareamento. Após o tratamento clareador, os espécimes foram irrigados com solução de hipoclorito de sódio a $0,5 \%$, conforme Paiva \& Antoniazzi (1988), tanto para completar-se a ação clareadora como para a hidratação da dentina.

Neste experimento utilizou-se o Single-Bond da 3M Dental Products, um sistema adesivo de $5^{\text {a }}$ geração (one-bottle total etch), pois o mesmo tem mostrado valores de adesão significativamente maiores que outros onebottle similares comercialmente disponíveis e também pela sua facilidade de aplicação segundo uma tendência atual dos fabricantes em reduzir o tempo de aplicação.

Segundo Barakat \& Powers (1986) o emprego de corpos de prova tronco-cônicos aumenta a possibilidade de falha na interface material restaurador-dentina e diminui o número de falhas por fratura do material restaurador (Mathias, 1998). 
A resina composta Tetric $^{\circledR}$ Ceram da Vivadent selecionada para a confecção dos corpos de prova é uma resina composta híbrida fotopolimerizável de partículas finas, constituída de matriz de monômero BisGMA dimetacrilato de uretano e trietilenoglicol dimetacrilato. A carga inorgârnica é constituída por vidro de bário, trifluoreto de itérbio, vidro de fluorsilicato de alumínio e bário, dióxido de silício e óxidos esferoidais, que Ihe conferem alta resistência ao desgaste, excelente textura superfficial, alta resistência à fratura e à degradação marginal assim como uma boa adaptação de cor, sendo indicada para a restauração tanto de dentes anteriores como posteriores.

Embora as metodologias de pesquisa empregadas neste experimento e no experimento de Rotstein (1993c) sejam differentes, ambos tiveram como proposta comum a neutralização do peróxido de hidrogênio residual. Uma vez que a presença deste no interior dos túbulos dentinários supostamente interfira com a polimerização do material restaurador objetivou-se a melhora das propriedades adesivas da dentina clareada através da imersão dos espécimes em soluções de Catalase. Enquanto o referido autor pipetava $20 \mu \mathrm{l}$ de Catalase de fígado bovino C-40, na concentração de $10 \mathrm{mg} / \mathrm{ml}$, no interior de câmaras pulpares de premolares humanos durante 3 min., neste experimento submeteu-se os espécimes à imersão em $250 \mathrm{ml}$ de Catalase de fígado de bovino C9322, em diferentes concentrações, pelo mesmo período. Os critérios adotados para a seleção da enzima Catalase C9322 (de 2.000 a 5.000 unidades/mg de proteína que atinge, segundo certificado de análise fornecido pelo laboratório, uma 
quantidade média de 3.300 unidades/mg de proteína) incluíram, principalmente, o seu menor custo operacional em relação a C-40, ser também produzida de fígado bovino assim como por apresentar-se comercialmente na forma de pó o que favoreceu a preparação das diversas soluções testadas.

A Catalase é uma enzima encontrada em praticamente todos os animais, plantas, bactérias e fungos mas as Catalases de fígado de mamíferos e de sangue têm sido as mais intensamente estudadas. hepatocatalase bovina, um termo para a Catalase obtida do fígado bovino, tem um peso molecular igual a 250.000 (Kiseler et al, 1967), um pH ótimo em torno de aproximadamente 7 e não necessitando de ativadores nem cofatores para a sua aividade.

Os resultados de ensaios de tração podem ser influenciados por fatores tais como a profundidade da dentina, a área do dente utilizada, a rugosidade da superfície testada e o tempo de armazenamento assim como o tipo de material testado. De uma forma geral, a avaliação da resistência adesiva do material restaurador tanto ao esmalte como à dentina, é realizada através de testes de tração e cisalhamento sendo que nos ensaios de tração tem-se uma distribuição de forças de forma mais homogênea. No entanto, os resultados de forças de adesão obtidos em testes laboratoriais na forma de ensaios de tração ou cisalhamento não expressam condições clínicas reais (Mathias, 1998 e Baratieri, 2001).

A análise dos resultados obtidos em nosso experimento, valores absolutos de Resistência Adesiva à fratura dos corpos de prova, evidenciou 
uma diminuição significativa das forças de adesão tanto para os grupos de espécimes tratados com Catalase como para os grupos de espécimes tratados com soro fisiológico (Grupos Controle), quando da comparação destes com os valores médios de força de adesão da resina composta à dentina não clareada. Segundo Perdigão et al. (2001) as forças de adesão entre a resina composta e a dentina variam entre 3 e $30 \mathrm{MPa}$ que resulta, portanto, em um valor médio de 16,5MPa. Supõe-se que fatores tais como a contração da resina composta durante sua fotopolimerização, a forma de armazenamento dos espécimes assim como a idade do dente possam influenciar os resultados dos experimentos.

Nos grupos experimentais em que os espécimes foram tratados com as diferentes concentrações de Catalase verificou-se, através do Teste de Kruskal-Wallis, diferenças estatisticamente significantes entre as amostras analisadas, ao nível de significância de 5\%, rejeitando-se a hipótese de nulidade. Os espécimes imersos em solução de Catalase 250mg apresentaram maiores valores de Resistência Adesiva em relação às outras amostras. Dessa forma, a análise comparativa das amostras analisadas permite inferir que a Catalase $250 \mathrm{mg}$ promoveu a melhora dos níveis de força adesiva.

Considerando-se as hipóteses relacionadas à diminuição da adesividade da dentina clareada, ou seja, o fato de que as alterações microestruturais e o oxigênio residual no interior da massa dentinária após o tratamento clareador interfiram diretamente com a adesividade do material restaurador, a comparação do grupo Catalase $250 \mathrm{mg}$ com o seu respectivo 
grupo controle permitiu-nos concluir que esta promoveu uma recuperação da adesividade dentinária provavelmente através da eliminação do peróxido de hidrogênio residual que interferiria com a fotopolimerização do material restaurador e reduziria a adesividade dentinária.

No entanto, quando da comparação da média dos valores de Resistência Adesiva do referido grupo com o valor médio de Resistência Adesvia de dentina não clareada, igual a 16,5MPa, notamos apenas uma melhora que supomos experimentalmente pouco expressiva. Apesar disso, a suposição de que concentrações mais altas de Catalase tivessem um melhor desempenho com a relação a restauração da força de união do material restaurador à dentina clareada, foi verificada.

A pesquisa da literatura científica relacionada à adesividade da resina composta em dentina humana clareada através de ensaios de tração não revela investigações que não as realizadas ao nível de esmalte humano e dentina bovina empregando-se na maior partes das vezes testes de cisalhamento. Ainda assim, os resultados dos experimentos realizados com esmalte empregando análise histoquímica ou Microscopia Eletrônica de Varredura são controversos. Em alguns destes experimentos não se verificam tais alterações enquanto que em outros constata-se um aumento da porosidade do esmalte de espécimes clareados (Perdigão et al., 1998; Rotstein et al., 1992; Canepa et al., 1993, Lewistein et al., 1994, Rotstein et al., 1996 e Zalkind et al., 1996).

Apesar de uma série de pesquisadores conjecturarem sobre as falhas de adesividade do material restaurador à dentina clareada relacionando-as 
às alterações microestruturais e ao oxigênio residual, ambos tanto ao nível de esmalte como de dentina, não esclarecem o mecanismo preciso de atuação dos mesmos. Relatam que o peróxido de hidrogênio residual ao interferir com a polimerização do material restaurador, sistema de adesivo dentinário e resina composta, promova falhas de natureza tanto adesiva como coesiva.

O sistema adesivo e a resina composta híbrida empregados neste experimento, materiais de última geração, tiveram como propósito contribuir no sentido do recuperação das forças de união entre a dentina e o material restaurador após o tratamento clareador. O adesivo dentinário empregado é constituído de uma fase hidrofílica e elaborado para ser aplicado à dentina úmida de tal forma não se utilizando de jato de ar, não se promova o colapso da cadeia de colágeno permitindo-se, dessa forma, a entrada dos monôneros do sistema adesivo e a formação da camada híbrida (Baratieri, 2001).

Considerando os resultados obtidos neste experimentos in vitro sugerimos que trabalhos adicionais devam ser conduzidos com espécimes de dentina clareada com o objetivo de se avaliar outras concentrações da enzima investigada. 


\section{CONCLUSÕES}

Dadas as condições experimentais estabelecidas, o presente trabalho permitiu concluir que:

1. O tratamento clareador promove uma diminuição das forças de adesão do material restaurador à dentina clareada;

2. A Catalase pode ser empregada como recurso auxiliar para a neutralização do peróxido de hidrogênio residual após o clareamento dental, visando uma melhor adesividade do material restaurador;

3. A Catalase foi efetiva na neutralização do peróxido de hidrogênio residual na concentração de $250 \mathrm{mg}$. 


\section{ANEXO A}

Tabela An.A8 - Valores originais das forças de tração necessárias para a fratura dos corpos de prova de cada um dos espécimes dos grupos experimentais e de seus respectivos grupos controle.

\begin{tabular}{ccccccccc}
\hline Esp. & $\begin{array}{c}\text { 1A } \\
\text { Catalase } \\
\text { 10mg }\end{array}$ & $\begin{array}{c}\text { 1B } \\
\text { Soro } \\
\text { Fisiol. }\end{array}$ & $\begin{array}{c}\text { 2A } \\
\text { Catalase } \\
\text { 50mg }\end{array}$ & $\begin{array}{c}\text { 2B } \\
\text { Soro } \\
\text { Fisiol. }\end{array}$ & $\begin{array}{c}\text { 3A } \\
\text { Catalase } \\
\text { 100mg }\end{array}$ & $\begin{array}{c}\text { 3B } \\
\text { Soro } \\
\text { Fisiol. }\end{array}$ & $\begin{array}{c}\text { 4A } \\
\text { Catalase } \\
\text { 250mg }\end{array}$ & $\begin{array}{c}\text { 4B } \\
\text { Soro } \\
\text { Fisiol. }\end{array}$ \\
\hline 01 & 13,97 & 17,95 & 27,10 & 26,56 & 21,62 & 14,72 & 35,52 & 28,34 \\
02 & 38,34 & 15,34 & 31,25 & 44,21 & 12,64 & 15,52 & 59,19 & 35,97 \\
03 & 9,758 & 39,97 & 28,56 & 26,83 & 23,11 & 10,74 & 46,01 & 10,38 \\
04 & 7,946 & 7,638 & 8,362 & 24,86 & 16,83 & 17,28 & 62,39 & 48,00 \\
05 & 28,98 & 27,81 & 53,07 & 63,52 & 32,82 & 20,46 & 38,75 & 45,58 \\
06 & 24,01 & 35,23 & 49,61 & 14,75 & 20,59 & 37,85 & 33,91 & 6,846 \\
07 & 10,59 & 15,01 & 16,86 & 34,42 & 16,16 & 6,658 & 37,22 & 13,09 \\
08 & 9,034 & 6,027 & 21,09 & 43,97 & 20,16 & 42,62 & 25,30 & 26,68 \\
09 & 38,59 & 8,403 & 10,71 & 65,88 & 32,63 & 35,77 & 20,93 & 15,03 \\
10 & 57,48 & 44,27 & 29,01 & 30,32 & 35,28 & 53,69 & 40,47 & 10,85 \\
\hline
\end{tabular}

unidade de medida: Newton 


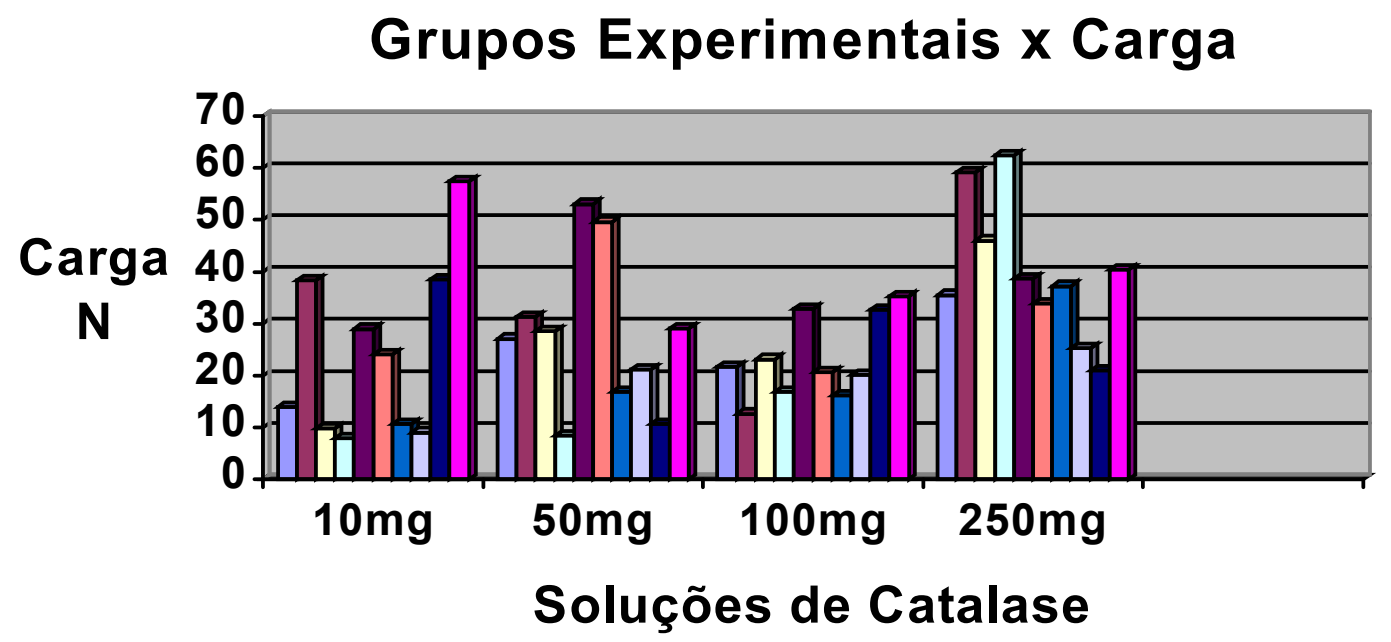

\begin{abstract}
$\square 1 \square 2 \square 3 \square 4 \square 5 \square 6 \square 7 \square 8 \square 9 \square 10$
Gráfico An.A4 - Valores originais das forças de tração necessárias para a fratura dos corpos de prova de cada um dos espécimes dos grupos experimentais.
\end{abstract}

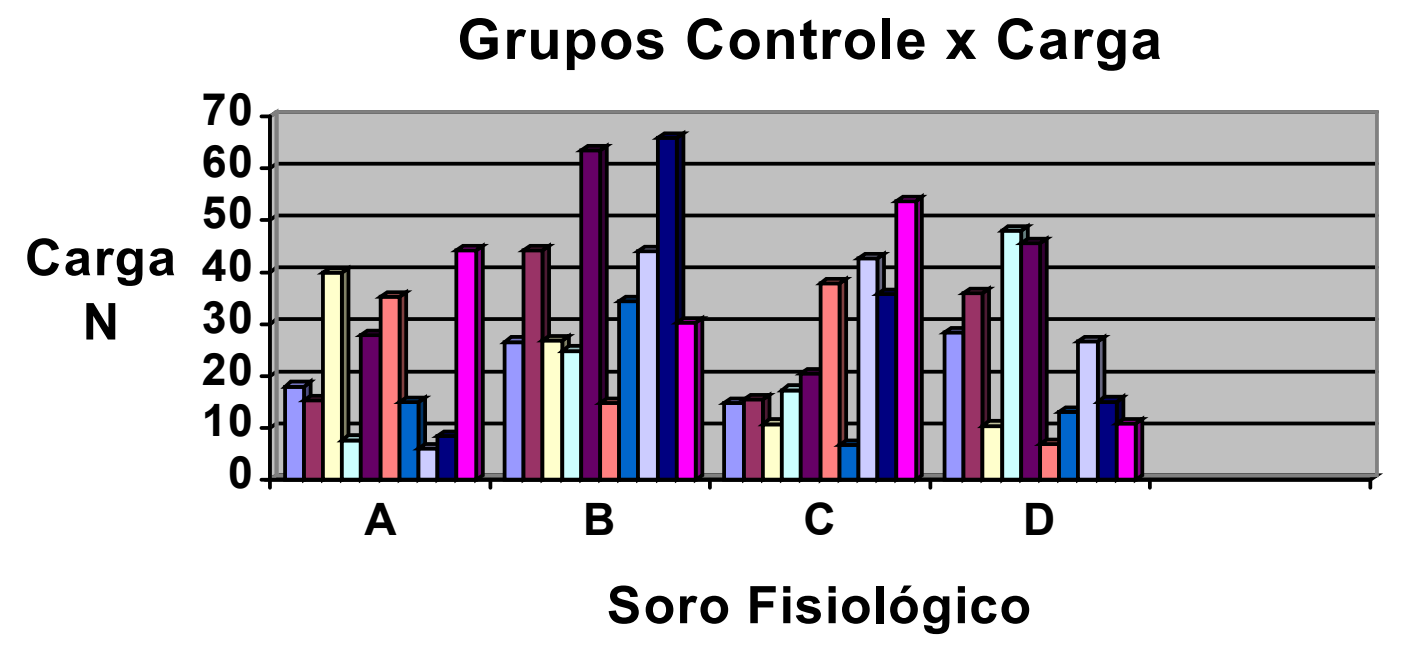

$\square 1 \square 2 \square 3 \square 4 \square 5 \square 6 \square 7 \square 8 \square 9 \square 10$

Gráfico An.A5 - Valores originais das forças de tração necessárias para a fratura dos corpos de prova de cada um dos espécimes dos grupos controle. 
Tabela An.A9 - Médias Aritméticas dos valores originais das forças de tração necessárias para a fratura dos corpos de prova dos grupos experimentais e dos seus respectivos grupos controle.

\begin{tabular}{c|cccc}
\hline & \multicolumn{4}{|c}{ Catalase } \\
& $1 \mathrm{~A}$ & $2 \mathrm{~A}$ & $3 \mathrm{~A}$ & $4 \mathrm{~A}$ \\
$\begin{array}{c}\text { Médias Aritméticas } \\
\text { dos valores de }\end{array}$ & 23,3 & 27,2 & 22,7 & 39,5 \\
carga & \multicolumn{4}{c}{ Controle } \\
& $1 \mathrm{~B}$ & $2 \mathrm{~B}$ & $3 \mathrm{~B}$ & $4 \mathrm{~B}$ \\
& 21,3 & 36,9 & 24,9 & 23,6 \\
\hline
\end{tabular}

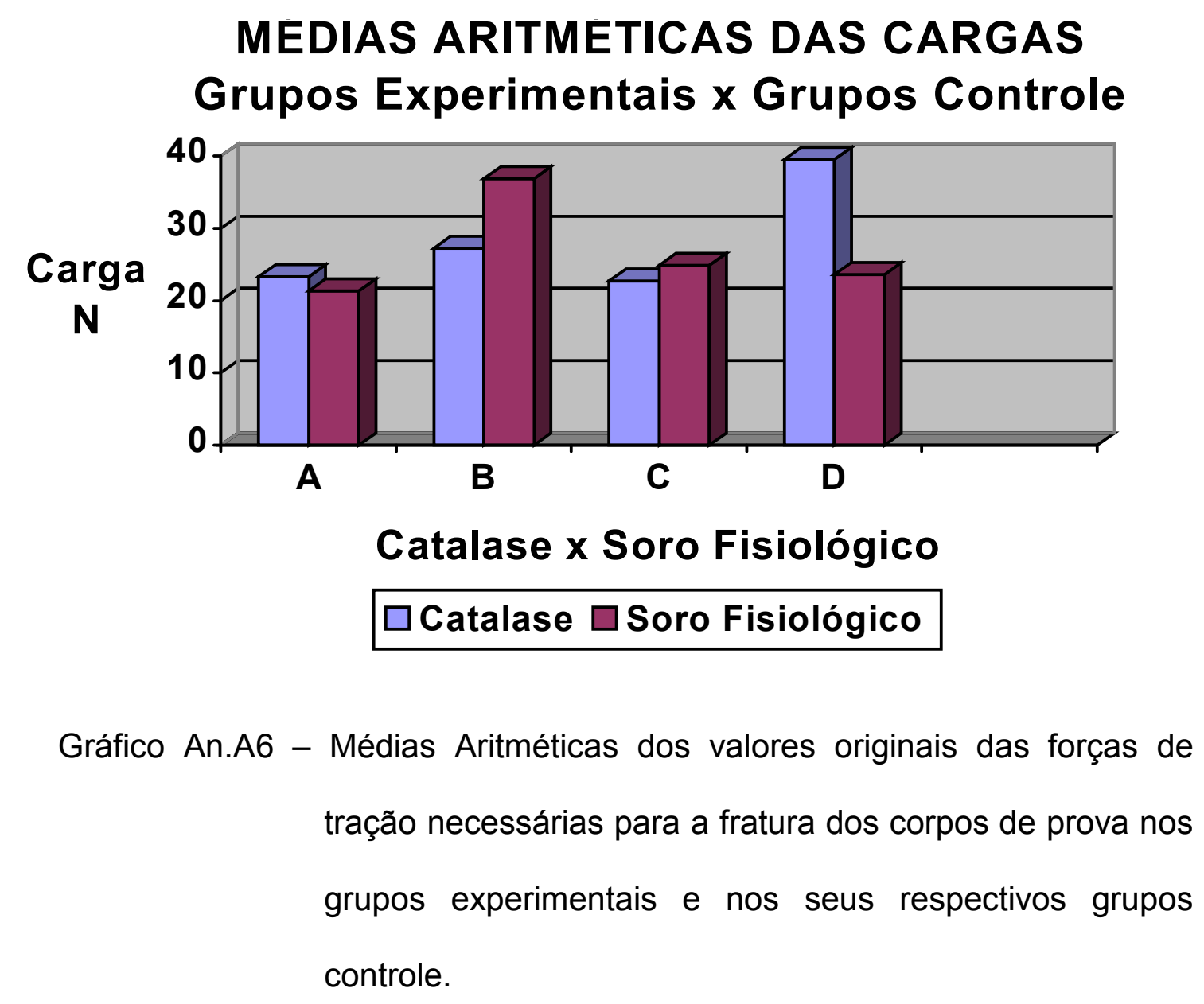


Tabela An.A10 - Teste de Normalidade das amostras de espécimes tratados com Catalase - Parâmetros Amostrais

\begin{tabular}{c|c}
\hline Parâmetros & Valores \\
\hline Soma dos dados amostrais & 0.0000 \\
Soma dos quadrados dos dados & 159.9000 \\
Termo de Correção & 0.0000 \\
Variação total & 159.9000 \\
Média Geral da Amostra & 0.0000 \\
Variância da amostra & 4.1000 \\
Desvio padrão da amostra & 2.0248 \\
Erro padrão da média & 0.3202 \\
Mediana por dados agrupados & 0.0000 \\
Número de dados da amostra & 0.0000 \\
Dados abaixo da média & 0.0000 \\
Dados iguais à média & 0.0000 \\
Dados acima da média & 0.0000 \\
\hline
\end{tabular}

Tabela An.A11 - Teste de Normalidade das amostras de espécimes tratados com Catalase - Distribuição de Freqüências

\begin{tabular}{cc|ccccccc}
\hline & & M-3s & M-2s & M-1s & Med. & M+1s & M+2s & M+3s \\
\hline Por intervalos & Absolutas & 0 & 0 & 16 & 13 & 7 & 4 & 0 \\
de classe & Percentuais & 0.0 & 0.0 & 40.0 & 32.5 & 17.5 & 10.0 & 0.0 \\
Acumuladas & Absolutas & 0 & 0 & 16 & 29 & 36 & 40 & 40 \\
& Percentuais & 0.0 & 0.0 & 40.0 & 72.5 & 90.0 & 100.0 & 100.0 \\
\hline
\end{tabular}


Tabela An.A12 - Teste de Normalidade das amostras de espécimes tratados com Soro Fisiológico (Grupos Controle) - Parâmetros Amostrais

\begin{tabular}{c|c}
\hline Parâmetros & Valores \\
\hline Soma dos dados amostrais & 0.0000 \\
Soma dos quadrados dos dados & 195.9750 \\
Termo de Correção & 0.0000 \\
Variação total & 195.9750 \\
Média Geral da Amostra & 0.0000 \\
Variância da amostra & 5.0250 \\
Desvio padrão da amostra & 2.2417 \\
Erro padrão da média & 0.3544 \\
Mediana por dados agrupados & 0.0000 \\
Número de dados da amostra & 0.0000 \\
Dados abaixo da média & 0.0000 \\
Dados iguais à média & 0.0000 \\
Dados acima da média & 0.0000 \\
\hline
\end{tabular}

Tabela An.A13 - Teste de Normalidade das amostras de espécimes tratados com Soro Fisiológico (Grupos Controle) - Distribuição de Freqüências

\begin{tabular}{cc|ccccccc}
\hline & & $\mathrm{M}-3 \mathrm{~s}$ & $\mathrm{M}-2 \mathrm{~s}$ & $\mathrm{M}-1 \mathrm{~s}$ & $\mathrm{Med}$ & $\mathrm{M}+1 \mathrm{~s}$ & $\mathrm{M}+2 \mathrm{~s}$ & $\mathrm{M}+3 \mathrm{~s}$ \\
\hline Por intervalos & Absolutas & 0 & 0 & 18 & 11 & 8 & 2 & 1 \\
de classe & Percentuais & 0.0 & 0.0 & 45.0 & 27.5 & 20.0 & 5.0 & 2.5 \\
Acumuladas & Absolutas & 0 & 0 & 18 & 29 & 37 & 39 & 40 \\
& Percentuais & 0.0 & 0.0 & 45.0 & 72.5 & 92.5 & 97.5 & 100.0 \\
\hline
\end{tabular}


Tabela An.A14 - Teste de Aderência à Curva Normal para as amostras dos espécimes tratados com Soro Fisiológico.

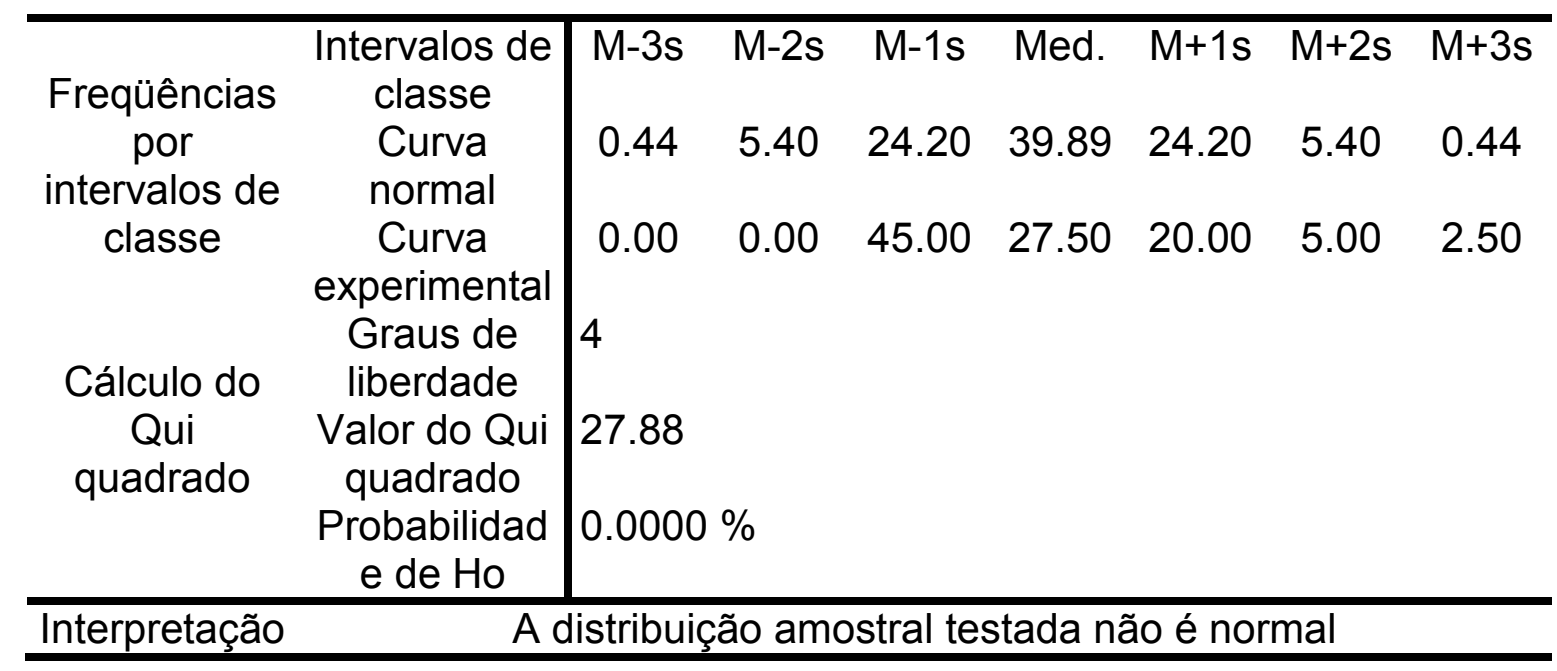

Tabela An.A15 - Teste de Kruskall-Wallis para os grupos controle.

\begin{tabular}{c|c}
\hline Valor $(\mathrm{H})$ de Kruskal-Wallis calculado & 9.8919 \\
Valor do $\mathrm{X}^{2}$ para 3 graus de liberdade & 9.89 \\
Probabilidade de Ho para esse valor & $1.95 \%$ \\
\hline \multicolumn{2}{c}{ O valor de H aparece repetido como $\mathrm{X}^{2}$ porque a sua significância avaliada pela } \\
tabela do qui-quadrado
\end{tabular}

Tabela An.A16 - Comparação das Médias dos grupos controle.

\begin{tabular}{|c|c|c|c|c|c|}
\hline \multicolumn{6}{|c|}{ Comparação entre Médias dos postos das amostras } \\
\hline \multirow{2}{*}{$\begin{array}{c}\text { Amostras comparadas } \\
\text { (comparações duas a duas) }\end{array}$} & \multirow{2}{*}{$\begin{array}{l}\text { Diferenças } \\
\text { entre } \\
\text { médias }\end{array}$} & \multicolumn{2}{|c|}{ Valores críticos } & \multirow{2}{*}{$\begin{array}{c}\text { (à) } \\
0.001\end{array}$} & \multirow[t]{2}{*}{ Significância } \\
\hline & & 0,05 & 0,01 & & \\
\hline CAT10B X CAT50B & 10.9500 & 10.0517 & 13.4841 & 17.7764 & $5 \%$ \\
\hline X CAT100B & 1.9500 & 10.0517 & 13.4841 & 17.7764 & ns \\
\hline X CAT250B & 0.4000 & 10.0517 & 13.4841 & 17.7764 & ns \\
\hline X CAT100B & 9.0000 & 10.0517 & 13.4841 & 17.7764 & ns \\
\hline CAT50B $\mathrm{X}$ CAT250B & 10.5500 & 10.0517 & 13.4841 & 17.7764 & $5 \%$ \\
\hline CAT100B X CAT250B & 1.5500 & 10.0517 & 13.4841 & 17.7764 & ns \\
\hline
\end{tabular}

$s-$ significante $n s-$ não significante 


\section{REFERÊNCIAS *}

ADIBFAR, A.; STEELE, A.; TORNECK, C. D.; TITLEY, K. C.; RUSE, D. Leaching of hydrogen peroxide from bleached bovine enamel. J Endod, Chicago, v. 18, n. 10, p. 488-491, Oct. 1992.

AUN, C. E.; MOURA, A. A. M. Clareamento dental. In: PAIVA, J.G.; ANTONIAZZI, J.H. Endodontia. Bases para a prática clínica. 2.ed. São Paulo: Artes Médicas, 1988. p. 759-777.

BARATIERI, L. N.; MONTEIRO JR., S.; ANDRADA, M. A. C.; VIEIRA, L. C. Introdução. In: BARATIERI, L. N.; MONTEIRO JR., S.; ANDRADA, M. A. C.; VIEIRA, L. C. Clareamento Dental. São Paulo: Livraria Santos Editora Ltda., 1996a. p. 01-03.

\footnotetext{
* De acordo com ABNT NBR-6023: 2000. Abreviatura de periódicos segundo Bases de Dados MEDLINE.
} 
BARATIERI, L. N.; MONTEIRO JR., S.; ANDRADA, M. A. C.; VIEIRA, L. C. Etiologia das alterações de cor. In: BARATIERI, L. N.; MONTEIRO JR., S.; ANDRADA, M. A. C.; VIEIRA, L.C. Clareamento Dental. São Paulo: Livraria Santos Editora Ltda., 1996b. p. 04-11.

BARATIERI, L. N.; MONTEIRO JR., S.; ANDRADA, M. A. C.; VIEIRA, L. C. Agentes Clareadores. In: BARATIERI, L. N.; MONTEIRO JR., S.; ANDRADA, M. A. C.; VIEIRA, L. C. Clareamento Dental. São Paulo: Livraria Santos Editora Ltda., 1996c. p. 12-22.

BARKHORDAR, R. A.; KEMPLER, D.; PLESH, O. Effect of nonvital tooth bleaching on microleakage of resin composite restorations. Quintessence Int, Berlin, v. 28, n. 5, p. 341-344, May 1997.

BOWLES, W. H.; BURNS JR., H. Catalase/Peroxidase activity in dental pulp. J Endod, Chicago, v. 18, n. 11, p. 527-529, Nov. 1992.

BUCKLEY, J. P. Agentes locais. In: BUCKLEY, J. P. Matéria Médica. Farmacologia e Terapêutica Dentárias. 2ed. Tradução Prof. Almeno de Souza. Editora Científica, 1950. p. 43-151.

CABRAL, B. F.; OLIVEIRA, N. L. Uso combinado das técnicas de clareamento dental extracoronário e intracoronário. Rev Assoc Paul Cir Dent, São Paulo, v. 55, n. 2, p. 105-107, Mar.-Abr. 2001. 
CANEPA, R.; SOUZA NETO, M. D.; SAQUY, P. C.; ROMANI, N. F.;

PÉCORA, J. D. Estudo in vitro da ação do agente clareador (perborato de sódio + peróxido de hidrogênio + calor) sobre a microdureza da dentina. Rev Paul Odont, São Paulo, v. 15, n. 4, p. 18-24, Jul./Ago. 1993.

CREWS, K.; DUNCAN, D.; LENTZ, D.; GORDY, F. M. Efect of bleaching agents on the chemical composition of enamel. Miss Dent Assoc J, Jackson, v. 53, n. 1, p. 20-21, Feb. 1997.

CVEK, M.; LINDVALL, A-M. External root resorption following bleaching of pulpless teeth with oxygen peroxide. Endod Dent Traumatol, Copenhagen, v. 1, n. 2, p. 56-60, Apr. 1985.

ESBERARD, R. M.; SIMÕES FILHO, A. P.; LEONARDO, M. R. Recuperação da cor natural dos dentes. In: LEONARDO, M. R.; LEAL, J. M. Endodontia. Tratamento de Canais Radiculares. 2ed. São Paulo: Editora Médica Panamericana, 1991. p. 515-524.

FORTUNA, C. R. Clareamento dos dentes vitais com gel de Peróxido de Carbamida a $10 \%$ com Carbopol e a possível alteração na força de adesão por cisalhamento de resinas compostas fotopolimerizáveis aplicadas ao esmalte clareado. 1996. 167 f. Dissertação (Mestrado em Dentística) - Faculdade de Odontologia , Universidade de São Paulo, São Paulo. 
FRANCISCHONE, C. E.; FRANCISCONI, P. A. S.; SOUZA JR, M. H. S.; MONDELLLI, J.; ISHIKIRIAMA, A. Resistência à fratura de dentes despolpados tratados com agentes clareadores. Rev Bras Odont, Rio de Janeiro, v. 43, n. 4, p. 02-05, Jul.-Ago 1986.

FRANK, A. L.; SIMON, J. H. S.; ABOU-RASS, M.; GLICK, D. H. Bleaching Procedures. In: FRANK, A. L.; SIMON, J. H. S.; ABOU-RASS, M.; GLICK, D. H. Clinical and Surgical Endodontics: Concepts in Practice. Philadelphia: J. B. Lippincott, 1983. p. 205-213.

FRIEDMAM, S.; ROTSTEIN, I.; LIBFELD, H.; STABHOLZ, A.; HELING, I. Incidence of external root resorption and esthetic results in 58 bleached pulpless teeth. Endod Dent Traumat, Copenhagen, v. 4, n. 1, p. 23-26, Feb. 1988.

GOLDSTEIN, R. E.; HAYWOOD, V. B.; HEYMANN, H. O.; STEINER, D. R.; WEST, J. D. Bleaching of Vital and Pulpless Teeth. In: COHEN, S.; BURNS, R. C. Pathways of the Pulp. 6ed. Saint Louis-MO: Mosby, 1994. p. 584-603.

GOTTMAN, K. General characteristics of technical enzymes. In: UHLIG, H. Industrial enzymes and their application. Trans. Elfriede M. LinsmaierBednar. New York: John Wiley \& Sons, Inc., 1998. p. 13-36. 
GROSSMAN, L. I. Branqueamento dos dentes. In: GROSSMAN, L. I. Tratamento dos canais radiculares. Tradução Sylvio Bevilacqua. Rio de Janeiro: Livraria Atheneu S/A, 1954. p. 443-453.

HARRINGTON, G. W.; NATKIN, E. External resorption associated with bleaching of pulpless teeth. J Endod, Chicago, v. 5, n. 11, p. 344-348, Nov. 1979.

HAYWOOD, V. B.; HAYMANN, H. O. Nightguard vital bleaching. Quintessence Int, Berlin, v. 20, p. 173-176, 1989.

HEITHERSAY, G. S. Invasive cervical resorption: An analysis of potential predisposing factors. Quintessence Int, Berlin, v. 30, n. 2, p. 83-95, Feb. 1999.

HELING, I.; PARSON, A.; ROTSTEIN, I. Effect of bleaching agents on dentin permeability to Streptococcus faecalis. J Endod, Chicago, v. 21, n.11, p. 540-542, Nov. 1995.

INGLE, J. I.; BAKLAND, L. K. Discoloration and bleaching. In: INGLE, J. I.; BAKLAND, L. K. Endodontics. 4ed. Malvern: Williams \& Wilkins, 1994. p. 868-875. 
LEINFELDER, K.F. New developments in resin restorative systems. J Am Dent Assoc, Chicago, v. 128, p. 573-581, May 1997.

LEWISTEIN, I.; HIRSCHFELD, Z.; STABHOLZ, A.; ROTSTEIN, I. Effect of hydrogen peroxide and sodium perborate on the microhardness of human enamel and dentin. J Endod, Chicago, v. 20, n. 2, p. 61-63, Feb. 1994.

LIEBENBERG, W. H. Intracoronal lightening of discolored pulpless teeth: a modified walking bleach technique. Quintessence Int, Berlin, v. 28, n. 12, p. 771-777, Dec. 1997.

MASUOKA, N.; WAKIMOTO, M.; UBUKA, T.; NAKANO, T.

Spectrophotometric determination of hydrogen peroxide: catalase activity and rates of hydrogen peroxide removal by erythrocytes. Clin Chim Act, Amsterdan, v. 254, p. 101-112, May 1996.

MATHIAS, R. S. Estudo comparativo sobre a resistência adesiva à dentina de molares decíduos entre quatro materiais restauradores, por ensaio de tração, in vitro. 1998. 74 f. Tese (Doutorado em Odontopediatria) - Faculdade de Odontologia , Universidade de São Paulo, São Paulo. 
MORAES, S. H.; ARAGÃO, E. M.; HECK, A. R.; MORAES, C. A. H. Resistência à fratura em dentes despolpados e clareados. RGO, Porto Alegre, v. 39, n. 4, p. 309-310, Ago. 1991.

MORAIS, L. D.; ROSA, R. L.; PAZIM, V. P. Clareamento em dentes com vitalidade pulpar. In: BERGER, C. R. Endodontia. São Paulo: Pancast Editora, 1998. p. 603-621.

NUTTING, E. D.; POE, G. E. A new combination for bleaching teeth. J S Calif Dent Assoc, California, v. 41, n. 2, p. 289-291, Feb. 1963.

OLIVARES, C. M. A.; SANTOS, J. F. F. Capacidade adesiva de cimentos de ionômero de vidro na dentina. Rev Odont USP, São Paulo, v. 9, n. 2, p. 115120, Abr./Jun. 1995.

PÉCORA, J. D.; NETO, M. D. S.; SILVA, R. G.; SAQUY, P. C.; VANSAN, L. P.; CRUZ FILHO, A. M.; COSTA, W. F. Desenvolvimento Histórico do Clareamento Dental. In: PÉCORA, J. D.; SOUZA NETO, M. D.; SILVA, R. G.; SAQUY, P. C.; VANSAN, L. P.; CRUZ FILHO, A. M.; COSTA, W. F. Guia de Clareamento Dental. São Paulo: Santos Livraria Editora, 1996a. p. 01-04.

PÉCORA, J. D.; NETO, M. D. S.; SILVA, R. G.; SAQUY, P. C.; VANSAN, L. P.; CRUZ FILHO, A. M.; COSTA, W. F. Etiologia das alterações de cor dos dentes. In: PÉCORA, J. D.; SOUZA NETO, M. D.; SILVA, R. G.; SAQUY, P. 
C.; VANSAN, L. P.; CRUZ FILHO, A. M.; COSTA W. F. Guia de Clareamento Dental. São Paulo: Santos Livraria Editora, 1996b. p. 05-09.

PÉCORA, J. D.; NETO, M. D. S.; SILVA, R. G.; SAQUY, P. C.; VANSAN, L. P.; CRUZ FILHO, A. M.; COSTA, W. F. Preocupações e dúvidas dos pesquisadores sobre o clareamento dental. In: PÉCORA, J. D.; SOUZA NETO, M. D.; SILVA, R. G.; SAQUY, P. C.; VANSAN, L. P.; CRUZ FILHO, A. M.; COSTA, W. F. Guia de Clareamento Dental. São Paulo: Santos Livraria Editora, 1996c. p. 35-43.

PÉCORA, J. D.; NETO, M. D. S.; SILVA, R. G.; SAQUY, P. C.; VANSAN, L. P.; CRUZ FILHO, A. M.; COSTA, W. F. Técnicas de clareamento de dentes tratados endodonticamente. In: PÉCORA, J. D.; SOUZA NETO, M. D.; SILVA, R. G.; SAQUY, P. C.; VANSAN, L. P.; CRUZ FILHO, A. M.; COSTA, W. F. Guia de Clareamento Dental. São Paulo: Santos Livraria Editora, 1996d. p. 15-29.

PERDIGÃO, J.; RITTER, A. V.; Adesão aos tecidos dentários. In: BARATIERI, L. N.; MONTEIRO Jr, S.; ANDRADA, M. A. C.; VIEIRA, L. C. C.; RITTER, A. V., CARDOSO, A. C. Odontologia Restauradora Fundamentos e Possibilidades. Editora Santos: São Paulo, 2001. p. 85-128.

PERDIGÃO, J.; FRANCCI, C.; SWIFT Jr., E. J.; AMBROSE, W. W.; LOPES, M. Ultra-morphological study of the interaction of dental adhesives with 
carbamide peroxide-bleached enamel. Am J Dent, San Antonio, v. 11, n. 6, p. 291-301, Dec. 1998.

PRINZ, H. Recent improvements in tooth bleaching. A clinical syllabus. Dent Cosmos, Chicago, v. 66, n. 6, p. 558-560, May 1924.

RAMOS, R. A. S.; VILLA, G. E. P. Influência do peróxido de carbamida $10 \%$ na cor de resinas compostas. Rev Odontol UNICID, São Paulo, v. 11, n. 2, p. 105-109, Jul.-Dez. 1999.

REIS, A.; CARRILHO, M. R. O.; LOGUERCIO, A. D.; GRANDE, R. H. M. Sistemas de Adesivos Atuais. J Bras Clin Odontol Int, Curitiba, v. 5, n. 30, p. 455-466, Nov./Dez. 2001.

ROTSTEIN, I.; FRIEDMAN, S. pH variation among materials used for intracoronal bleaching. J Endod, Chicago, v.17, n.8. p. 376-379, Aug. 1991.

ROTSTEIN, I.; TOREK, Y.; LEWINSTEIN, I. Effect of bleaching time and temperature on the radicular penetration of hydrogen peroxide. Endod Dent Traumatol, Copenhagen, v. 7, n. 5, p. 196-198, Oct. 1991a.

ROTSTEIN, I.; TOREK, Y.; MISGAV, R. Effect of cementum defects on radicular penetration of $30 \% \mathrm{H}_{2} \mathrm{O}_{2}$ during intracoronal bleaching. J Endod, Chicago, v. 17, n. 5, p. 230-233, May 1991b. 
ROTSTEIN, I.; LEHR, Z.; GEDALIA, I. Effect of bleaching agents on inorganic components of human dentin and cementum. J Endod, Chicago, v. 18, n. 6, p. 290-293, Jun. 1992 a.

ROSTSTEIN, I.; LEWISTEIN, I.; ZUWABI, O.; STABHOLZ, A.; FRIEDMAN, M. Effect of cervical coating of etil cellulose polymer and metacrylic acid copolymer on the radicular penetration of hydrogen peroxide during bleaching. Endod Dent Traumatol, Copenhagen, v. 8, n. 5, p. 202-205, Oct. 1992b.

ROTSTEIN, I.; MOR, C.; FRIEDMAN, S. Prognosis of intracoronal bleaching with sodium perborate preparations in vitro: 1-year study. J Endod, Chicago, v. 19 , n. 1, p. 10-12, Jan. 1993 a.

ROTSTEIN, I.; WESSELINK, P. R.; BAB, I. Catalase protection against hydrogen peroxide-induced injury in rat oral mucosa. Oral Surg Oral Med Oral Pathol, St Louis, v. 75, n. 6, p. 744-750, Jun. 1993b.

ROTSTEIN, I. Role of Catalase in the elimination of residual hydrogen peroxide following tooth bleaching. J Endod, Chicago, v.19, n. 11, p. 567569, Nov. 1993c. 
ROTSTEIN, I.; COHENCA, N.; MOR, C.; MOSHONOV, J.; STABHOLZ, A. Effect of carbamide peroxide and hydrogen peroxide on the surface morphology and zinc oxide levels of $\mathrm{IRM}^{\circledR}$ fillings. Endod Dent Traumatol, Copenhagen, v. 11, n. 6, p. 279-283, Dec. 1995.

ROTSTEIN, I.; DANKNER, E.; GOLDMAN, A.; HELING, I.; STABHOLZ, A.; ZALKIND, M. Histochemical analysis of dental hard tissues following bleaching. J Endod, Chicago, v.22, n.1, p. 23-26, Jan. 1996.

SCHONBAUM, G. R.; CHANCE, B. Catalase. In: BOYER, P. D. The Enzymes. 3ed. New York: Academic Press, 1976. p. 363-408.

SHORTALL, A. C.; WILSON, H. J. Novos materiais, tratamentos de adesão e alterações na prática restauradora. In: McLEAN, J.; WILSON, H. J.; BROWN, D. Materiais dentários e suas aplicações. Tradução Sérgio B. Martins. São Paulo: Livraria Editora Santos, 1989. p. 01-12.

SILVA E SOUZA Jr., M. H.; OLIVEIRA, M. R. Resistência adesiva em esmalte de dentes clareadoss. ROBRAC, Goiânia, v. VI, n. 22, p. 48-51, 1997.

SILVEIRA, F. F.; BERGER, C. R. Clareamento em dentes sem vitalidade pulpar. In: BERGER, C.R. Endodontia. São Paulo: Pancast Editora, 1998. p. $625-632$. 
SPYRIDES, G. M.; PERDIGÃO, J.; PAGANI, C.; ARAÚJO, M. A. M.; SPYRIDES, S. M. M. Effect of whitening agents on dentin bonding. J Esthet Dent, Canada, v. 12, n. 5, p. 264-270, 2000.

TEIXEIRA, F. B.; NOGUEIRA, E. C.; FERRAZ, C. C. R.; ZAIA, A. A. Clareamento dental interno com pasta de perborato de sódio e água destilada. Rev Assoc Paul Cir Dent, São Paulo, v. 54, n. 4, p. 315-318, Jul.Ago. 2000.

TITLEY, K.; TORNECK, C. D.; SMITH, D. C. Effect of concentrated hydrogen peroxide solution on the surface morphology of cut human dentin. Endod Dent Traumatol, Copenhagen, v. 4, n. 1, p. 32-36, Feb. 1988 a.

TITLEY, K.; TORNECK, C. D.; SMITH, D. The effect of concentrated hydrogen peroxide solutions on the surface morphology of human tooth enamel. J Endod, Chicago, v. 14, n. 2, p. 69-74, Feb. 1988b.

TITLEY, K. C.; TORNECK, C. D.; SMITH, D. C.; ADIBFAR, A. Adhesion of composite resin to bleached and unbleached bovine enamel. J Dent Res, Chicago, v. 67 , n. 12 , p. 1523-1528, Dec. 1988 c.

TITLEY, K. C.; TORNECK, C. D.; SMITH, D. C.; APPLEBAUM, N. B. Adhesion of a glass ionomer cement to bleached and unbleached bovine 
dentin. Endod Dent Traumatol, Copenhagen, v. 5, n. 3, p. 132-138, Jun. 1989.

TITLEY, K. C.; TORNECK, C. D.; SMITH, D. C.; CHERMECKY, R.; ADIBFAR, A. Scanning electron microscopy observations on the penetration and structure of resin tags in bleached and unbleached bovine enamel. $\mathbf{J}$ Endod, Chicago, v. 17, n. 2, p. 72-75, Feb. 1991.

TITLEY, K. C.; TORNECK, C. D.; RUSE, N. D. The effect of carbamideperoxide gel on the shear bond strength of a microfil resin to bovine enamel. J Dent Res, Chicago, v. 71, n. 1, p. 20-24, Jan. 1992.

TITLEY, K. C.; TORNECK, C. D.; RUSE, M. S.; KMEC, D. Adhesion of a resin composite to bleached and unbleached human enamel. J Endod, Chicago, v. 19, n. 3, p. 112-115, Mar. 1993.

TORNECK, C. D.; TITLEY, K. C.; SMITH, D. C.; ADIBFAR, A. The influence of time of hydrogen peroxide exposure on the adhesion of composite resin to bleached bovine enamel. J Endod, Chicago, v.16, n. 3, p. 123-128, Mar. 1990.

TORNECK, C. D.; TITLEY, K. C.; SMITH, D. C.; ADIBFAR, A. Effect of water leaching on the adhesion of composite resin to bleached and unbleached bovine enamel. J Endod, Chicago, v. 17, n. 4, p. 156-160, Apr. 1991. 
TROPE, M. Cervical root resorption. J Am Dent Assoc, Chicago, v. 128 suppl, p. 56-59, Apr. 1997.

UHLIG, H. Description of enzymes. In: UHLIG, H. Industrial enzymes and their application. Trans. Elfriede M. Linsmaier-Bednar. New York: John Wiley \& Sons, Inc. 1998. p. 37-202.

van der VYVER, P. J.; LEWIS, S. B.; MARAIS, J. T. The effect of bleaching agent on composite/enamel bonding. J Dent Assoc S Afr, Cape Town, v. 52, n. 10, p. 601-603, Oct. 1997.

WILSON, H. J. Restauradores à base de resina. In: McLEAN, J.; WILSON, H. J.; BROWN, D. Materiais dentários e suas aplicações. Tradução Sérgio B. Martins. São Paulo: Livraria Editora Santos, 1989. p. 88-100.

YASMINEH, W. G.; THEOLOGIDES, A. Catalase as roving scavenger of hydrogen peroxide: A hypothesis. J Lab Clin Med, St Louis, v. 122, p. 110114, Jul. 1993.

ZALKIND, M.; ARWAZ, J. R.; GOLDMAN, A.; ROTSTEIN, I. Surface morphology changes in human enamel, dentin and cementum following bleaching: a scanning electron microscopy study. Endod Dent Traumatol, Copenhagen, v. 12, n. 2, p. 82-88, Apr. 1996.. 20. P. 341-401. 


\section{SUMMARY}

\section{IN VITRO EVALUATION OF THE ROLE OF CATALASE IN DIFFERENTS CONCENTRATIONS ON RESIN BOND STRENGTH TO BLEACHED DENTIN}

The teeth color changes have diverse etiology and they can come out as consequence of intrinsic as extrinsic factors. Intrinsic factors can be congenital or acquired and these last can disclose so before as after tooth eruption. Crown color changes from acquired factors are related to nonvital as to endodontic treated teeth. This way pulp degradation byprocutcs can infiltrate the dentin tubules and change the crown color in nonvital teeht. Root canal therapy iatrogenic factors regarding crown staining comprise the presence of pulp remmanents in pulp chamber, intracanal medicaments and endodontic cements or sealsers. Even in 1850 Dwinelle have suggested that teeth could be bleached with Hydrogen Peroxide and in 1979 Natking \& Harrington have reported cervical external root resorption as an adverse effect in bleaching endodontic treated teeth. Among the undesirerable effects of teeth bleaching researchers have been reporting such a reduction in the adhesive bond strength of the bleached dentin that would be probably related 
to tissue microstructural changes and the presence of residual Oxigen inside the structures. In 1993 Rotstein et al. have employed the enzyme Catalase for inactvating this residual Oxygen to not allow it to diffuse to the external root surface. The current in vitro experiment have evaluated the role of Catalase in the neutralization of Hydrogen Peroxide looking for reestablishent of the normal dentin bond adhesion characteristics. Seccionated forty teeth provide eighty specimens whose were bleached with a paste made of $30 \%$ Hydrogen Peroxide and Sodium Perborate. Subsequentely all specimens were immersed in four differents Catalase solutions during 3min. KruskalWallis tests revealed statistically signifcant reduction in bond strengths for the specimens treated with Catalase $250 \mathrm{mg}$. 


\section{AUTORIZAÇÃO}

Autorizo a reprodução e/ou divulgação total ou parcial da presente obra, por qualquer meio convencional ou eletrônico, desde que citada a fonte e comunicada, ao autor, a referência em que consta a citação.

Silvia Helena Buendia

Assinatura

Instituição / Departamento: Faculdade de

Odontologia da Universidade de São Paulo - São Paulo(SP) / Departamento de Dentística

Local e data: São Paulo(SP), 30 de Março de 2003.

Endereço: Rua Samia Haddad, 150 - apto 82 Morumbi - São Paulo-SP - CEP: 05709-050

E-mail: jacgomes@uol.com.br 